\title{
In-between: \\ Phantom Public and the Suburban Territory
}

by

Nancy E. Chao, B.A.S.

A thesis submitted to

The Faculty of Graduate Studies

in partial fulfillment of

the requirements for the degree of

\section{MASTER OF ARCHITECTURE}

M.ARCH. (Professional)

Carleton University

Ottawa, Ontario

September, 2006

(C) copyright

2006, Nancy E. Chao 


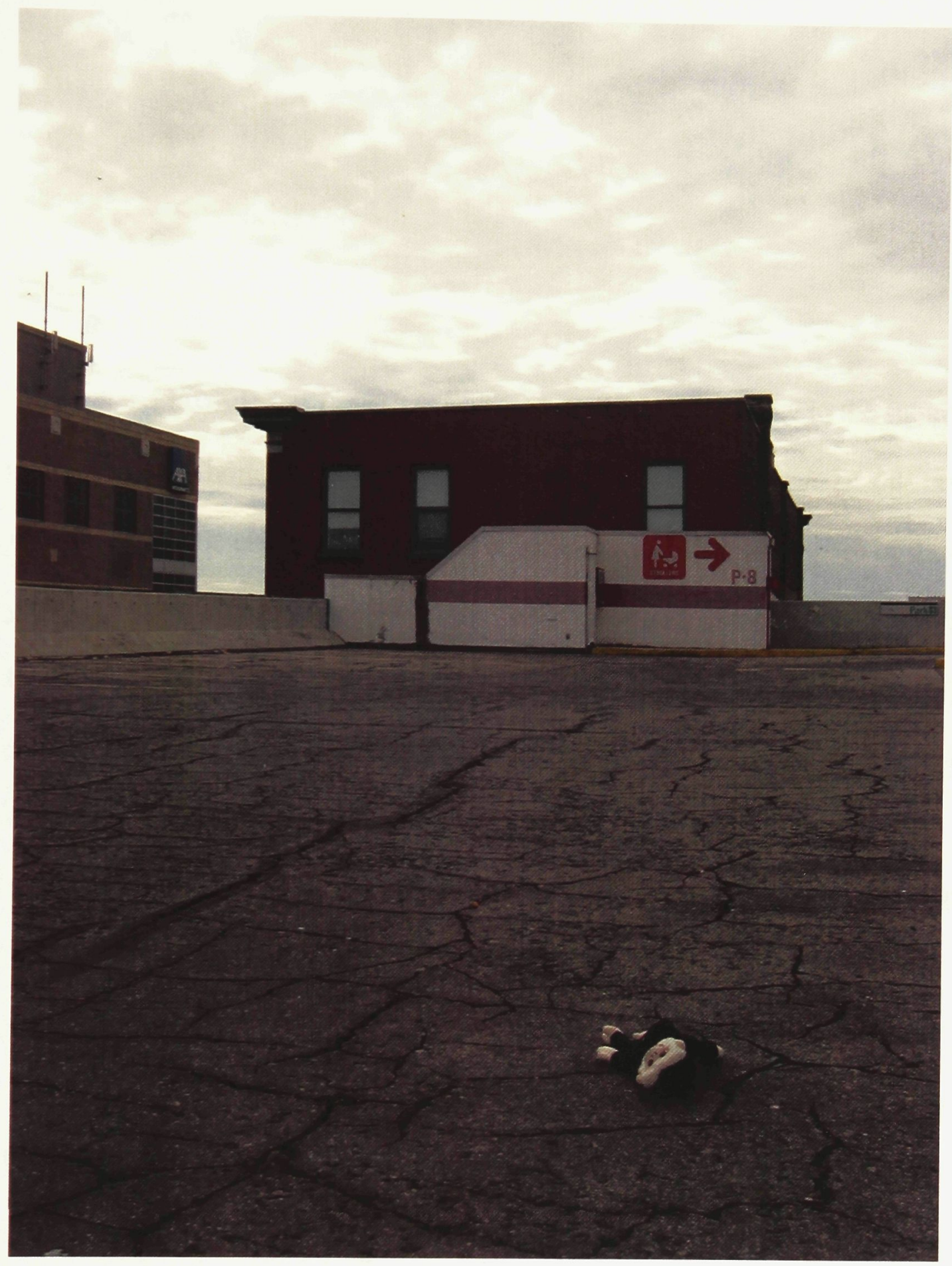




\section{Abstract}

This thesis investigates the re-conceptualization of public space in the suburban territory. Guided by Thomas Keenan's notion of the Phantom public sphere, this thesis will explore democratic challenges made to the existing organizational space of the city through the subversion or modification of the social structures of the public sphere within the suburban realm. Keenan's idea that public space has no absolute social basis proposes the creation of a heterogeneous and indeterminate public sphere; its meaning is unstable, thus susceptible to democratic contestation and change.

The first theme of investigation challenges typical notions of public space through the examination of the suburban territory, using the ideology of public art as a scale of intervention and criticism. The second theme presents the design component as an integrated multi-use building in the Westmount Shopping Centre in London, Ontario that is defined by the juxtaposition of its public and private functions. The introduction of an unfamiliar building typology in the suburbs will create new layers of inhabitation and the emergence of a Phantom public sphere. 


\title{
Acknowledgments
}

\author{
Thank you to Professor Brian \\ Lonsway, my advisor, for \\ introducing me to Rosalyn \\ Deutsche and to Keenan's \\ notion of the Phantom Public \\ Sphere. Without his help this \\ would not be possible.
}

I must also thank my family for their encouragement, and more importantly, for their patience and love.

Finally, I would like to thank all my friends for their support and to Andrew Pressburger for his kind words. 
1. PUBLIC SPACE AND SPATIAL POLITICS: SOCIO-POLITICAL ANTAGONISM AS

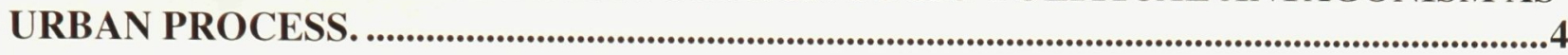

Habermas: Constructing a Universal Public Sphere …............................................................. 6

Phantom Public Sphere: The Creation of an Alternative Space.............................................. 9

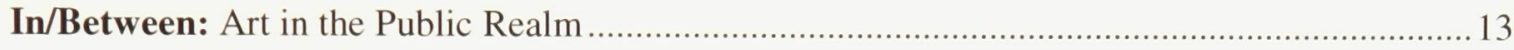

2. FROM CITY TO SUBURB: UNIFICATION AND FRAGMENTATION OF URBAN

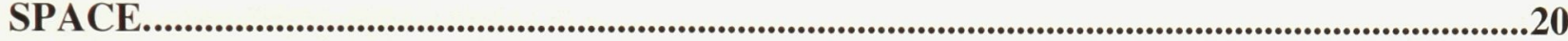

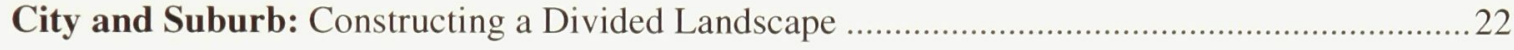

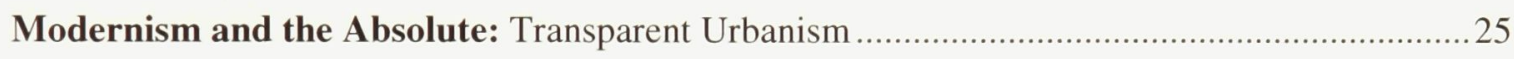

Frank Lloyd Wright: The Decentralization of the Modern Plan ..............................................2 27

3.THE CITY IN-BETWEEN: CONTEMPORARY SUBURBAN LANDSCAPES...............32

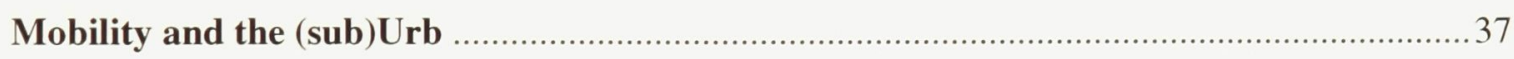

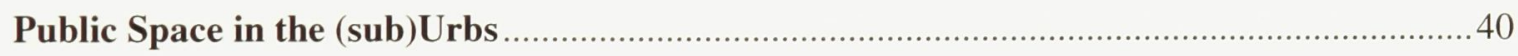

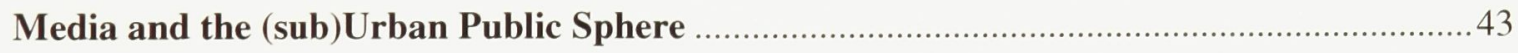

4. CONSUMING SPACE: THE 'MALLIFICATION' OF THE (SUB)URB .........................48

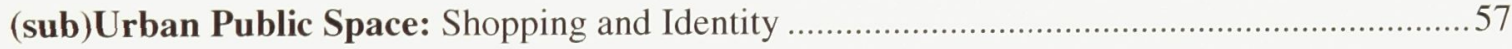

5. UNVEILING THE PHANTOM PUBLIC: DEVELOPING A MIXED-USE TYPOLOGY

FOR THE (SUB)URBS.........................................................................................................64

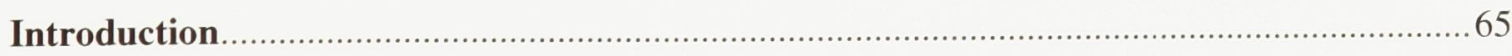

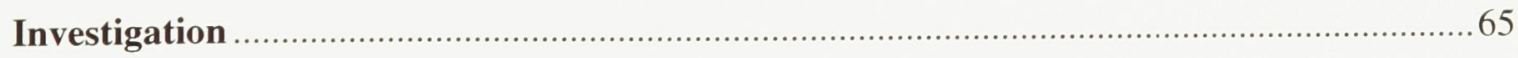

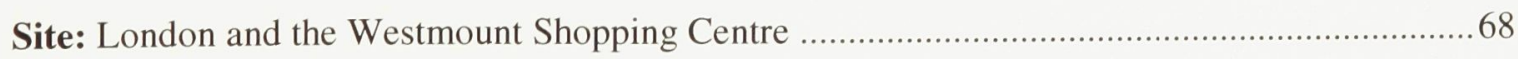

Investigating the City: Production of a Contested Landscape ……......................................... 78

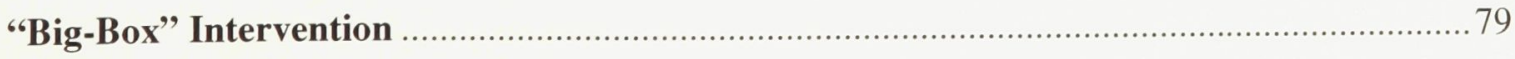


Parking Void

Road Signs ……

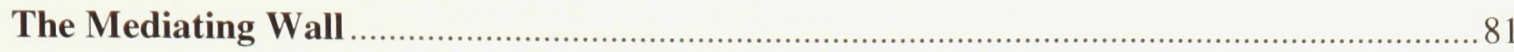

New Typology: Programmatic and Formal Relations ................................................................94

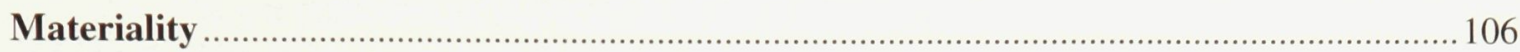

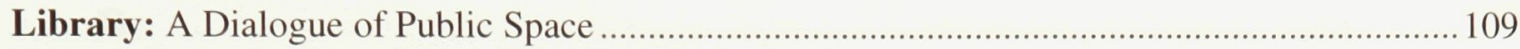

CONCLUSION

APPENDIX A

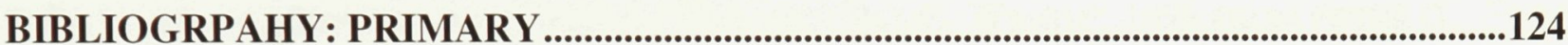

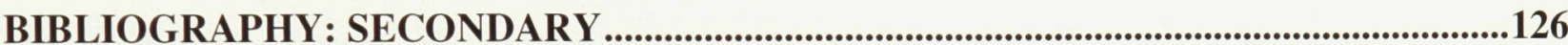




\section{List of Figures}

1: MARTHA Rosler'S "IF YOU LIVEd Here..." EXHIBITION ENTRANCE IN SOHO FROM IF YOU Lived Here: The City in ART, TheOry, AND SOCIAL ACTIVISM (SEATTLE, WASHington, 1991) 60

2: INSTALLATION OF "HOME FRONT" BY MARTHA ROSLER, 1989, WITH MAYOR KOCH'S INFAMOUS QUOTE. FROM ROSALYN DEUTSCHE, “ALTERNATIVE SPACE”, IF YOU LIVED Here: The City in ART, Theory, And Social ACtivism (SEATtLe, Washington, 1991) 60.

3: CITY TO SUBURB, LONDON, ONTARIO 2006, PHOTOGRAPHED BY AUTHOR.

4: RADBURN, NEW JERSEY By ClARENCE STEIN AND HENRy WRight, 1928 FROM PETER G. Rowe, MAKING A Middle LANDSCAPE (CAMBridge: The MIT Press. 1991) 219.......

5: GARDEN CITY PLAN BY EBENEZER HOWARD, FROM WILLIAM J.R. CURTIS, MOdERN ARCHITECTURE SiNCE 1900 (LONDON: PHAIDON PRESS LIMITED. 1996) 243.

6: LE CORBUSIER, CONTEMPORARY CITY FOR 3 MILLION INHABITANTS, 1922, WITH GLAZED SKYSCRAPERS AND MULTI-LEVEL TRANSPORT TERMINAL AT THE CITY CENTRE FROM William J.R. Curtis, Modern ARChitecture Since 1900 (LONDON: Phaidon Press LIMITED. 1996).

7: FRANK LLOYD WRIGHT, BROADACRE CITY PROJECT, 1934-5, MODEL FROM WILLIAM J.R. CURTIS, Modern ARCHITECTURE SinCE 1900 (LONDON: PHAIDON PRESS LiMited. 1996) 316.

8: (BUMPER) CARS, 2006, PHOTOGRAPHS BY AUTHOR.

9: CITY, RAIL \& ROAD, 2006, PHOTOGRAPHED BY AUTHOR. 34

10: NATURE REBUILDING, 2006, PHOTOGRAPHS BY AUTHOR 35

11: (RIGHT) LEVITTOWN, NEW YORK UNDER CONSTRUCTION, 1950, (LEFT) LEVITTOWNERS INFRONT OF THEIR HOME, 1948, PETER G. ROWE, MAKING A MidDle LANDSCAPE (CAMBRIDGE: THE MIT PRESS. 1991) 51-52.

12: EARLY MORNING TAI CHI, 2006, WESTMOUNT MALL, PHOTOGRAPHS BY AUTHOR.

13: SHOPPING CARTS, WESTMOUNT MALL, 2006, PHOTOGRAPHS BY AUTHOR.

14: CODES OF ENTRY, 2006, WeSTMOUNT MALL, PHOTOGRAPHS BY AUTHOR.

15: SOUTHDALE MALl IN EDINA, MinNESOTA, 1956 SHOWING PLANS, AERIAL AND INTERIOR COURT FROM JEFFREY M. HARDWICK, MALl MAKER: VICTOR GRUEN, ARCHITECT OF AN AMERICAN DREAM (PHILAdELPHIA: UNIVERSITY OF PENNSYLVANIA PRESS, 2004) 143-145. 
16: GALLERIA COMPLEX SHOWING ICE SKATING RINK, HOUSTON TEXAS, FROM PETER G. ROWE, MAKING A MidDle LANDSCAPE (CAMBridge: The MIT PRESS. 1991) 129.

17: Deep Sea Adventure at West Edmonton Mall, Alberta From HTTP://WWW.CS.UALBERTA.CA/ ACOMAN/IMAGES/CANADA/EDMONTON/100_0103.JPG...55

18: BEST'S PEELING PROJECT DESIGNED By SITE IN 1972 FROM NANCY GOLDRING, "HIGHWAY ARCHITECTURE.” ED. WOMERSLEy, STEVE. SITE IDENTITY AND DENSITY. (VICTORIA: THE IMAGES PUBLISHING GROUP PTy LTD. 2005) 42.

19: (FROM LEFT TO RIGHT) SITE'S INDETERMINATE FACADE BUILDING, FOREST SHOWROOM, INSIDE/OUTSIDE BUILDING BUILT BETWEEN 1975-1984, FROM NANCY GOLDRING, SITE IDENTITY AND DENSITY. (VICTORIA: ThE IMAGES PUbLishing GROUP PTY LTD., 2005) 44, $58,57$.

20: SuRREY CENTRAL CITY, BRITISH COLUMBIA BY BING THOM 2003 FROM ELLEN DUNHAMJONES,. “SUbURBAN RETROFITS, DEMOGRAPHICS, AND SUSTAINABILITY” PlaCES VOL. 17.2 (SUMMER 2005) 9.

21: SHOP LIFT LOOKING AT SMALL RETAIL ABOVE FROM GEORGE WAGNER, "SHOP LIFT". CANADIAN ARCHITECT VOL. 50.9 (2005) 60.

22: SuRRey British COLUMBia, GEORGE Yu'S AERIAL VIEW OF SHOP LIFT, 2004 FROM GEORGE WAGNER, "SHOP LIFT". CANADIAN ARCHITECT VOL. 50.9 (2005) 60.

23: IMAGES BY AUTHOR, 2006 64

24: AERIAL PHOTO SHOWING THE SITE OF WESTMOUNT MALL IN RELATION TO LONDON'S DOWNTOWN CORE

25: MALL TO MALL TO MALL, (TOP) DOWNTOWN, (MIDDLE) WESTMOUNT, (BOTTOM) SOUTH LONDON PERIPHERY. PHOTOGRAPHS BY AUTHOR, 2006.

26: Westmount Shopping Centre, South FACAde Facing Viscount Rd., 2006, PHOTOGRAPHS BY AUTHOR.

27: Westmount ShOPPING CENTRE, 2006 (TOP) EAST FACADE, (BOTTOM) NORTH FAÇADE, PHOTOGRAPHS BY AUTHOR.

28: WESTMOUNT MALL INTERIOR, 2005, (LEFT) HOLIDAY EVENTS, (RIGHT) SKYLIGHTS ALLOW MAXIMUM NATURAL LIGHTING, PHOTOGRAPHED BY AUTHOR.

29: WESTMOUNT MALL, 2006, (TOP) SHOWING MAIN INTERIOR CORRIDOR, (BOTTOM) SHOWING CIRCULATION, PHOTOGRAPHED BY AUTHOR

30: WALKING MAP FOR THE WESTMOUNT SHOPPING CENTRE SHOWING FOUR ROUTES, FROM A WESTMOUNT SHOPPING CENTRE BROCHURE.

31: MAJOR AUtOMOBILE AND PUbliC TRANSPORTATION ROUTES

32: BUILDING TyPeS AND MAIN PEDESTRIAN ROUTES 
34: DIAGRAMS (LEFT TO RIGHT), EXISTING MALL, RESIDENTIAL AND CIVIC PROGRAMMES, EXISTING MEANS OF EGRESS, EXISTING MAIN PEDESTRIAN ROUTES, PROPOSED CIRCULATION ROUTES.

35: INTERVENTION PANELS, (TOP TO BOTTOM): PARKING VOID, BIG-BOX, MEDIATING WALL, ROAD SIGNS, SURVEY GRAPH.

36: DIAGRAM .85

37: SKETCHES FOR CONCEPTUAL MODEL .85

38: CONCEPT MODEL (TOP) FROM ABOVE SHOWING SURVEY 'VIEWER', CONFLICT WITHIN SPACE, INTER VENTIONS IN SPACE (BOTTOM) ELEVATION OF CONCEPT MODEL. 86

39: DETAILS FROM CONCEPTUAL MODEL. THE PLASTER CAST REPRESENTS AN OBSTRUCTION IN A FORMAL ORGANIZATION.

40: LOOKING FROM ABOVE, BURO KIEFER'S PLAYGROUND AND PARKING SPACE. .88

41: MODEL, STUDY OF WESTMOUNT MALL'S PEDESTRIAN CIRCULATION FROM SURROUNDING PROGRAMMES .90

42: COLLAGE STUDIES, (TOP) SHOWING CIRCULATION AND PRELIMINARY PROGRAMMING, (BOTTOM) INVESTIGATING MULTI-USE SURFACES AND OVERLAPPING PROGRAMMES.

43: COLLAGE MODELS, EXPERIMENTING WITH SHARED SURFACES FOR HOUSING UNITS. .92

44: COLLAGE MODEL STUDY OF JUXTAPOSED URBAN AND SUBURBAN POPULATION AND INHABITATION DENSITIES.

45: KEY PLAN SHOWING NEW PROGRAMME (GREY), EXISTING MALL (YELLOW), AND OTHER PROPOSED BUILDINGS (WHITE).

46: ORGANIZATIONAL STRATEGY FOR THE WESTMOUNT MALL SITE,(TOP) KEY PLAN SHOWING SITE AND SURROUNDING AREA, (MIDDLE) SHOWING RESIDENTIAL MASSING GRID, (BOTTOM) SHOWING PUBLIC BUILDINGS BASED ON SUBURBAN PLANS. MODEL SCALE: 1:500

47: ORGANIZATIONAL MODEL SHOWING DETAILS OF LAYERED SPACES. 100

48: PRELIMINARY SKETCHES FOR MULTI-USE PROGRAMME 101

49: KEY PLAN FOR 1:200 MODEL, AREA OF INVESTIGATION: WESTSIDE OF THE WESTMOUNT MALL ANCHOR STORE AND PARKING.

50: MODEL SHOWING ARCHITECTURAL INTERVENTION ON THE SOUTH-WEST ANCHOR OF THE WESTMOUNT SHOPPING CENTRE. CLOCKWISE FROM TOP LEFT: SHOWING SOUTHEAST CORNER LIBRARY INTERVENTION, MANIPULATED SKYLIGHT AND HOUSING, SHOWING APARTMENTS, HOUSING, THEATRE AND PATH TO MALL, BOTTOM RIGHT: SHOWING POOL, LIBRARY AND APARTMENTS. 
51: (TOP) LOOKING AT SOUTH FACADE, (BOTTOM) LOOKING AT LIBRARY.

52: (TOP) NORTH ENTRANCE, (BOTTOM) LOOKING WEST ABOVE APARTMENTS AND RESIDENTIAL.

53: HOUSE MODULES SHOWING THREE TYPES: DUPLEX AND SINGLE. 105

54: MODULES, BRICK AND FIBREGLASS MOLDED UNITS FOR HOUSES AND PUBLIC BUILDINGS, RESPECTIVELY. 108

55: (TOP) SHOWING KEY PLAN OF THE LIBRARY WITHIN THE WESTMOUNT MALL CONTEXT, IMAGE SHOWING LIBRARY ACROSS FROM THE ZELLER'S ENTRANCE, LOOKING WEST.

56: CONSTRUCTING THE LIBRARY

57: LIBRARY ELEVATIONS

58: (TOP) SECOND FLOOR PLAN, (BOTTOM) FIRST FLOOR PLAN 114

59: LIBRARY (TOP) STUDY CARRELS, (BOTTOM) OFFICE SPACE ABOVE AND LIBRARY ENTRANCE.

60: (TOP) SHOWING STAIRWELL AND MOVING WALL PANELS (BOTTOM) OFFICE SPACE OVERLOOKING RESIDENTIAL AND OPEN SPACE OF MALL. 116

61: (TOP) OFFICE SPACE AND LIBRARY ENTRANCE, (BOTTOM) SOUTH FACADE OF LIBRARY 117 


\section{Introduction}

The contemporary suburban territory is currently undergoing a transformation. Periphery and central city have blended to form a shapeless and fractured landscape. Hybrid territories have developed where the distinction between city, suburb, and countryside is no longer self-evident. The morphology of the suburban city can be described as a discontinuous fabric where varying densities of population and building are displaced from the central urban core.

Once an animated and popular destination, the Galleria Shopping Center in London, Ontario's downtown core has failed to compete with the demand of suburban shopping malls. By now suburban shopping centers, too, like the Westmount Shopping Center located in the South-West periphery of London, are increasingly becoming vacant due to the growing number of "big box" stores which are once again causing a shift in the population to the periphery of the city. The need to re-evaluate the unoccupied landscapes of the city is crucial in the redevelopment of the social field for the residents who inhabit those spaces.

Inherent in the idea of traditional urban planning is the desire to live as a collective, while the suburban condition is intended to support an individual lifestyle and consequently more private condition. This urban paradigm can serve as a model in the reinterpretation of the suburban realm, particularly in regards to how a transformation of this space can communicate to the dense urban fabric of the core area, creating a direct relationship between the urban and suburban territories. 
The creation of a regional relationship between city core and suburb is dependent on the diversity of the suburban population and the integration of a variety of programmes whose land is not separated by function but rather, form a complex layering of spaces that establishes the potential for informal meetings and unconventional intersections of private and public space.

As an initial investigation into the subject of the public realm, this paper will investigate the idea of art in the public realm to further expand the notion and discussion of the public realm in the suburbs. Therefore, “... by connecting public art as a function of responsibility to the urban context, it can be viewed as a function of urbanism and not of art." The idea of site specificity in public art originally developed to counter the construction of autonomous art objects in public space. A revolution in the ideology of art was conceived and emphasized the need for space and art to share imperatives to politicize the production and convergence of space, utility and art. Rosalyn Deutsche refers to this convergence as "public art as a spatial activity"2. The manipulation of the function of public art in its contribution to the creation of suburban public space upholds the potential to create a platform for the public to promote their specific interests.

This thesis will focus on Thomas Keenan's notion of the phantom public sphere and Rosalyn Deutsche's notion of public space, which implies a model of democratic plurality and reinforces the concept of individual private identities in a shared public forum. Through the intervention of the proposed architectural spaces, the public realm will have the potential for a differentiated and heterogeneous public to emerge. Keenan and Deutsche's observations of public space will frame my investigation of the suburban territories. A programme of dynamic multi-functional buildings acts as a connective 
tissue between the central and peripheral regions of the Westmount Shopping Center. Combined with a diversification of programmes within the site, the densification of public and private entities includes a variety of residential, community, retail and open public space. The suburban condition that currently exists in London will be confronted with a renewed vision of public space and meaning. 


\section{Public Space and Spatial Politics:}

Socio-Political Antagonism as Urban Process

"We will not capture the truth of public space by recovering its origins...the recovery of origins does not reveal the essential, unchanging meaning of a concept; it shows, on the contrary, that meanings are conditional, formed out of struggles. Precisely because the "essence" of publicness is a historically constituted figure that grows and changes, the public is a rhetorical instrument open to diverse, even antagonistic, uses that vary with widely differing contexts."

Rosalyn Deutsche, "Evictions: Art and Spatial Politics" (1996) ${ }^{3}$ 


\section{Politicizing the Public Sphere}

Public space occupies an important ideological position in democratic societies. The notion of public space as both form and ideology can be traced back to the Greek Agora and its function as an open space where public affairs and legal disputes were conducted. While the Agora was a political space, it was also a market place, a place of gathering, bargaining, and decision making. Politics, commerce, and social entertainment were intertwined, providing a meeting place for strangers, whether citizens, buyers, or sellers. Although the ideal of the agora encouraged unmediated interaction, it was restricted to a privileged and homogenous group of people that shared common distinctions of political and economic power, legal rights and social respectability. ${ }^{4}$

Iris Marion Young discusses the problems that the privileged space of the agora has evoked in our current understanding of the public realm. Since the normative ideal of public space is premised on the idea of the agora, it rarely allows for encounters of those who share different perspectives, experiences and affiliations. Young concedes that the public space of the city should be "... an urban experience, defined by conflicting demands for the right to the city."5 For example, the perceived adversity to homeless people is often confronted with a negative response from the privileged public. Although these homeless groups of people generate a conflict within what would ideally exist in a normative public democracy, their citizenship to these public spaces is undoubtedly undermined.

Henri Lefebvre defines social space as the inhabitation and appropriation of traditional public space. Thus this space is transformed from what he calls a representation of space, where planned, controlled and ordered areas exist, to 
representational space, which describes the lived space of everyday experience. ${ }^{6}$ If public spaces emerge out of the relationship between representations of space and representational space, then they are spaces for representation - places where political or social discourse can take place. Therefore, for marginalized groups that claim space in the public realm, they themselves become "public" and are represented as an authentic part of society. $^{7}$

Historically, the Westernized notion of "the public" and the nature of public democracy developed dialectically, both literally and ideologically through the recognition of private property and the private sphere. Defined by Nancy Fraser in her article Rethinking the Public Sphere, she states that that the public sphere is the "... opposite of the 'private' sphere in the sense that it is a locus of "talk", ... a space in which citizens deliberate about their common affairs...". ${ }^{8}$ The nature of public interaction in the developing democracy of the United States provided the accessibility for any citizens to move between private property and public space. In the context of the American capitalist state citizenship is defined in terms of a process whereby critical public forums are formed by the owners of private property. "Public" implied citizenship to these privatized public spaces. According to this interpretation, the public sphere is conceived by the exclusion from a privileged group of people who were defined by their gender, class and race.

Habermas: Constructing a Universal Public Sphere 
German philosopher and sociologist Jurgen Habermas believed the public sphere was a singular and universal entity. His dogmatic view of the public domain attempted to universalize a model of discourse that developed within a specific historical development, the rise of 18 th century male-dominated bourgeois population. He believed that the public sphere was realized as a concept during the enlightenment. ${ }^{10}$ The use of reason for public criticism demanded a public forum that would provide a base for discussion for the bourgeois society as counterweights to absolutist states. Habermas' analysis of bourgeois public space suggested that it engaged in activities that mediated a space which existed between the governing public and private realms. This elite society was able to generate a critical distinction between the private and political realms, placing the public realm into the context of society and state, in order to pursue financial gain that would be unaffected by society or the state. Habermas believed that the boundary which provided the division between public and private life - the privileged space of politics was crucial for the conservation of the public realm. In his view the public sphere was jeopardized with the introduction of non-bourgeois groups such as mass media and the welfare state. ${ }^{11}$ Appearance of these antagonistic groups was seen by Habermas as the distinguishing factor in the public space's eventual decline.

In Nancy Fraser's Essay Rethinking the Public Sphere, she disputes Habermas' notion of 'public space'. Fraser believes that since Habermas refers to the "private" as "... everything that is outside of the domestic or familial sphere," he conflates "...the state, the official economy of paid employment, (to the) arenas of public discourse". ${ }^{12}$ Ideally, Habermas' idea of a public sphere resides on the fact that the bourgeois publics would mediate between society and state by requiring that information about state functioning 
be made accessible so that its activities could be subject to critical scrutiny by the public. But Fraser points out that what actually occurred was the transmittal of the considered "general interest" of "bourgeois society" to the state via forms of legally guaranteed free speech, free press, and free assembly. The idea of the public sphere designated a method for rationalizing political control by making states accountable to the selected citizens through unrestricted rational discussion of public matters. But, the bourgeois conception of the public sphere was premised on a social order in which the state was sharply differentiated from the newly privatized market economy; it was this clear separation of society and state that was supposed to underpin a form of public discussion that excluded "private interests." But the Bourgeois acted as its own exclusive entity where the norms of the public sphere eventually became "... hegemonic, sometimes imposed on, sometimes embraced by, broader segments of society". ${ }^{13}$ But that was eventually eroded as non-bourgeois groups gained access to the public sphere. Fraser believes that Habermas is suggesting that in order to attain democracy in a public realm, a universal comprehensive public sphere is preferred over the multiplicity of competing publics. She states that "...since there can be no such lens that is genuinely culturally neutral, (one public) would effectively privilege the expressive norms of one cultural group over others and thereby make discursive assimilation a condition for participation in public debate... (resulting in) the demise of multiculturalism and... social equality". ${ }^{14}$

Habermas' idea of the 'loss of public space', also endorsed by authors such as Richard Sennett, was challenged by Beate Roessler in Malcolm Miles book, Urban Avant Gardes. ${ }^{15}$ Roessler specifically condemns Sennett's conclusions about the loss of public space and believes that his pessimistic view was symptomatic of the postmodern 
condition and its corollary, late capitalism, which denoted a shift in architecture from a unitary centre to a fragmented urban space. She notes that it was contemporary society's attachment to mobile phones and various modes of media which allowed for the extension and disintegration of boundaries that exist in Habermas' notion of public space and the decline of the bourgeois public sphere. Roessler suggests that the divided public space has instead become decentralized rather than completely lost. ${ }^{16}$ She does not suggest an absolute shift in the meaning of public and private life, but a reinterpretation of the processes that defines the boundaries between private and public space.

The public space of the modern city has always been a place fraught with contradictions and different activities such as commerce and politics. In the modern metropolis, construction of a mall's authoritative and corporatized image of the market is similar in ideology of the traditional Greek Agora, since this entails a homogenization of a public body through exclusionary tactics. Moreover, the diversity of the public occurs in a controlled space so that shopping centers are able to profit from and encourage a type of diversity that is strictly bound to the consumption of commodity.

\section{Phantom Public Sphere: The Creation of an Alternative Space}

“...the public sphere rises as a phantom only at the moment of a disappearance."

The constitution of a democratic public based on the conflicting nature of differentiated social groups, will allow for the emancipation of a public realm. In her book Evictions: Art and Spatial Politics, Rosalyn Deutsche uses Chantal Mouffe's 
description of democratic public space to support her notion of public space. Mouffe believes that politics is established by the spatializing operations of a political community. If democracy proposes that the political community has no absolute social basis, then defining the operations which exist in a public space is itself a political process. Therefore, public space is inherently exclusive and dependent on conflict and instability. For example, the uprising in 1989 at Tiananmen Square, Beijing saw student activists transform the official square - a space of representation - into a place of political discourse. ${ }^{18}$ Thus the political public sphere was not only a site of discourse but it is also a radically constructed site. Contrary to the modernist conception of space, the public sphere remains democratic through its exclusions and openness to contestation. ${ }^{19}$

Deutsche's reasoning is also inspired by the writings of Claude Lefort, who provides crucial insight into her argument against the rhetoric of a universalizing and singular public domain. Lefort advances the notion of a democratic public sphere that is unlike Habermas' concept of an absolute hierarchical organization, such as a monarchy. He suggests that the 18th century formulation of The Declaration of the Rights of Man produced a democratic power shift from that of a singular totalizing state power to a pluralistic public. Lefort believes that democracy is the recognition that power, which was no longer derived from an absolute origin but only from an unstable source called "the people," became what he calls an "empty place". ${ }^{20}$ In her book Hegemony \& Socialist Strategy, written with Ernesto Laclau, Chantal Mouffe explains the difference between politics and political action where “... the political is antagonism and contestation between forces, whereas politics consists in giving form or embodying the political." 21 
The public is sustained in a limitless democracy that stays connected to the dissolution of social order and implies that the place of the public sphere remains void. Similarly, Deutsche proposes that the language of democracy is capable of interrupting authoritative public space because it possesses the capacity to continually question power and their existing social orders. ${ }^{22}$

Deutsche's critical perspective on public space creates an alternative to Habermasian public space. Her alternative has the capacity to become an instrument to help produce public space and question homogenous privatized pubic space. Deutsche argues that conflict is the constitutive condition of democratic public sphere that determines the nature of public space. Inherent in the conflicting nature of public space is its attachment to social, political, artistic, ritualistic, and historical meanings associated with it to give importance to the social foundation. While absolutist definitions of public space, like those theorized by Habermas, produce an exclusionary and privatized public realm, Deutsche's idea of public space attempts to offer solutions to the kind of social and political homogeneity that typically eradicates conflict through the implementation of a plural contested notion of democratic public space. Deutsche states that

"Totalitarianism ruins democracy by attempting to fill the void created by democratic revolution and banish the indeterminacy of the social". 23

The creation of an alternative public sphere begins with the discussion of Bruce Robbins, interpretation of a public space that is dedicated to an indeterminate social structure. Robbins calls this space the "phantom public sphere" (adopted from Walter Lippmann who coined the phrase in 1925). ${ }^{24}$ Robbins denies the possibility of a unified public and proposes the idea of a phantom public, challenging the Habermasian ideal. 
Although the phantom public represents the ideal of social coherence, Robbins asserts that the traditional public sphere is phantom-like because the term "public" is inherently deceptive and oppressive. He maintains that the traditional public sphere is itself a phantom because of its attempt to achieve social coherence. Robbins believes that this type of ideal public is merely an illusionary guise that represses differences and individuality. ${ }^{25}$ Viewing the public through the lens of a "phantom public sphere" allows for an alternative critique of this phenomenon in decline, by being critical of the systems that generate the meaning of the public sphere. He states that the "public sphere invokes 'identity', but does so with more emphasis on actions and their consequences than on the nature and characteristics of the actors". ${ }^{26}$ Although Robbins' explanation of the phantom public sphere explains how the lost public sphere is phantom-like, Thomas Keenan develops this idea to suggest that the appearance of the public's phantom-like qualities is what determines a public space. ${ }^{27}$ In his compelling account of the Phantom Public he suggests that the public sphere can not be lost but rather it continues to remain in a constant limbo that can be defined by its resistance to being made present.

Keenan uses the metaphor of the window in his essay Windows: of Vulnerability, to differentiate between the private and public realms. Based on Beatriz Colomina's writing, Keenan postulates the form and meaning of windows to the contemporary debate between public and private space. Since the implied notion of the window denotes a relationship between the interior and exterior, Keenan equates this with the boundary existing between the private and public realms. ${ }^{28}$ By linking the human subject to his theory, Keenan suggests that the transparency of the gaze through the window challenges the absolutist idea of defining boundaries that occur between public and private spaces. 
Keenan's discussion on the relationship of language to public space suggest that since language is composed of signifiers that require the relationship of other signifiers in order to generate meaning, public space is inherently dependent. Ultimately, he views language as unstable and public. "... without a final term and therefore always in need of additions and open to disruptions - language is a singularly public and singularly unstable medium."29

Keenan's public space is not a universalizing space; rather the emergence of the phantom public occurs when the presence of conflict is produced as a primary condition to generate a democratic and socially dynamic public forum. The phantom public sphere's ability to appear and fade with the disappearance of an absolute social basis provides that new social movements can be considered. It denies the construction of an authoritative social structure that can be objectified and instead presents the public sphere with uncertainty and impermanence. ${ }^{30}$ Invariably, this creates a public sphere that is interdependent on the differences that exist between and amongst social groups.

In/Between: Art in the Public Realm 


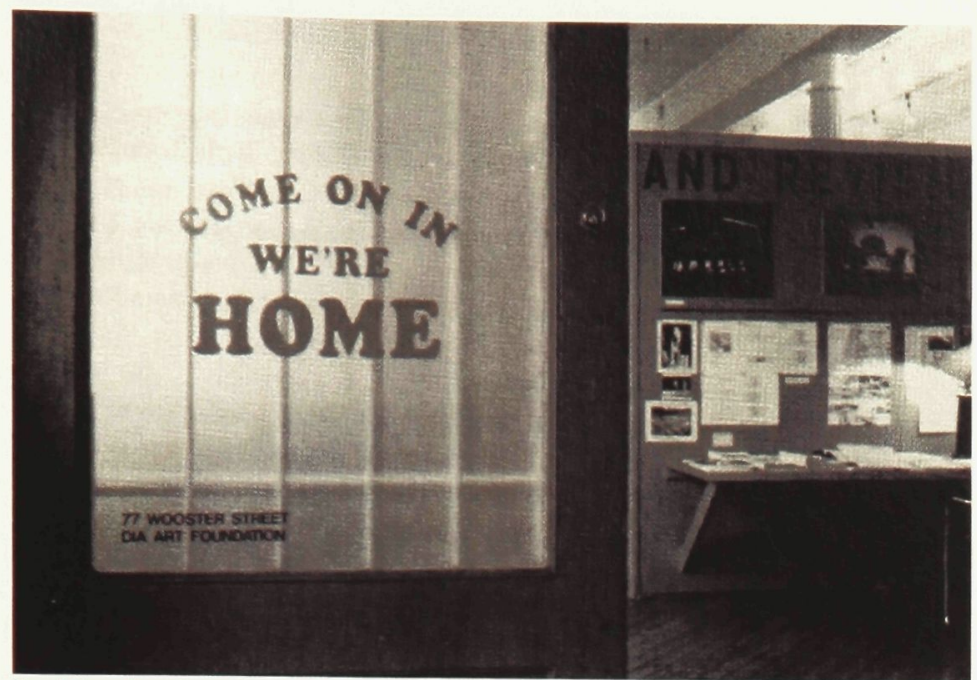

1: Martha Rosler's "If You Lived Here..." exhibition entrance in Soho from If You Lived Here: The City in Art, Theory, and Social Activism (Seattle, Washington, 1991) 60.
In the creation of a phantom public

sphere, a variety of ideas to

mobilize public space must exist.

Rosalyn Duetsche suggests that

since identity and meaning are

formed in public space, in order to

transcend a singular description of

public space, artistic interventions

that support new social movements

should be explored. ${ }^{31}$ Art that is public participates in or creates a political space and is itself a space where political identities are solidified. In her essay, Public art: $a$ Renewable Resource, Patricia Phillips supports the use of art to inhabit the boundary between the private and public realms. She believes that in this space, there is opportunity to make the public aware of its actions and challenge their existing behavioural relationships with one another, politically, economically or socially. ${ }^{32}$ The elasticity of these transient boundaries allows for interpretation and meaning to be discovered or uncovered through their metaphorical representation. Furthermore, because of its public disposition, public art belongs to both everyone and no one. Sustained in-between the private and public domains, public art remains a complex and provoking threshold. But this immaterial space drifts within a realm that is similar to the phantom public sphere proposed by Keenan. The multiplicity of the public art inherently allows for difference to be recognized and assumed in a public forum. 
"Like the space between bones, it hardly exists. But the space is indispensable to the activity and agency of the body." ${ }^{, 33}$ Expressed in this way, art can be seen as a dynamic exchange of invention and production rather than a stable collection of formal

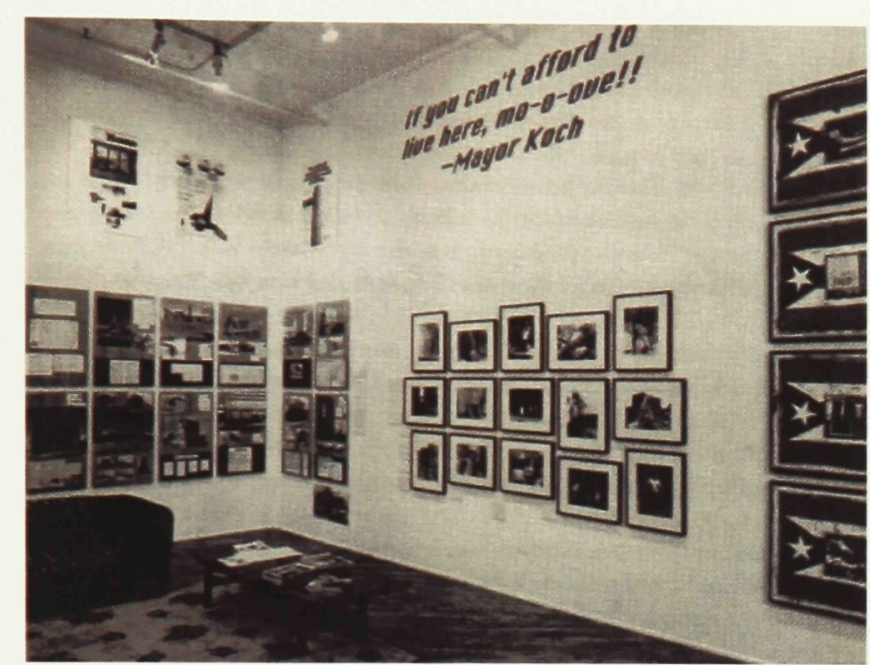

2: Installation of "Home Front" by Martha Rosler, 1989, with Mayor Koch's infamous quote. From Rosalyn Deutsche, "Alternative Space", If You Lived Here: The City in Art, Theory, and Social Activism (Seattle, Washington, 1991) 60 . characteristics. Martha Rosler

provides evidence for this type of

art in her series of discussions and

exhibitions titled "If you lived

here..." In this exhibition Rosler

investigates how space is socially

produced, perceived and used. Her

installations challenge ideas

introduced by urban developers into areas of degeneration and economic collapse. Her desire to express the interdependent nature of social relations and spatial organizations suggests that the "...city is not only formed by society, but can be considered the very material form of society". ${ }^{34}$ She seeks to transform conventional perceptions and uses of space, and produce a deviation in social space and the emergence of an alternative public realm. Its title, "If you lived here...", was borrowed from a real estate slogan and took place in the Soho district of Manhattan, New York. The inevitable by-product of gentrification that occurred in Soho in the 1980's left many displaced residents without a home. The increased prices for real estate meant that these exercises in capitalist urbanization would deny inhabitants the opportunity to remain in the area. Inside Rosler's exhibition was a quote from Mayor Koch: "If you can't afford to live here, move!" Addressed to the poor, 
Koch's statement was a reminder of the exclusivity of the gentrified neighbourhood. The importance of Rosler's exhibition confronts the reality of the artist's role in the developing city. By encouraging a critical spectatorship of the gallery and the city, Rosler's exhibition attempted to create an alternative public space out of the undemocratic nature of contemporary urbanization. ${ }^{35}$

Public art that shares similar characteristics with forms of social activism has the potential to expand the critical processes that form a civic public realm. Public art that operates in or as a public sphere participates in, or creates a political space and is itself a space where we assume political identities. Phillips' description of public art insinuates its identity in public space through its existence within the seams of the public and private realm that is also characteristic of Thomas Keenan's Phantom Public sphere. The complementary process of public art and Keenan's Phantom Public sphere demonstrate how Rosler gives identity to the critical actions which challenge exclusionary public space, while Keenan derives the forum where these identities can take place. 


\section{Chapter 1 Notes}

${ }^{1}$ Rosalyn Deutsche, "Uneven Development: Public Art in New York City,” Out of Site: A Social Criticism of Architecture, Ed. Diane Ghirardo (Seattle: Bay Press, 1991)

${ }^{2}$ Ibid. 170

${ }^{3}$ Rosalyn Deutsche, Evictions: Art and Spatial Politics. (Cambridge: The MIT Press. 1996) 290. Here Deutsche is referring to statements made by Friedrich Nietzsche.

${ }^{4}$ Don Mitchell, The Right to the City: Social Justice and the Fight for Public Space (New York: The Guildford Press, 2003) 132.

${ }^{5}$ Ibid. 131.

${ }^{6}$ Ibid. 129 .

${ }^{7}$ Ibid 129.

${ }^{8}$ Nancy Fraser, "Rethinking the Public Sphere: A Contribution to the Critique of Actually Existing Democracy", Social Text vol. 25/26,1990. 57. Habermas views the public sphere as a "[...] theater in modern societies in which political participation is enacted through the medium of 'talk'". He was weary of mediums of communication, like the media, which did not include 'face-to-face' discourse.

${ }^{9}$ Mitchell, op. cit. 132.

${ }^{10}$ Rosalyn Deutsche, Evictions: Art and Spatial Politics (Cambridge: The MIT Press. 1996) 287.

${ }^{11}$ Mitchell op. cit. 131.

${ }^{12}$ Nancy, Fraser, "Rethinking the Public Sphere: A Contribution to the Critique of Actually Existing Democracy." Habermas and the Public Sphere, ed. Craig

Calhoun (Cambridge: MIT Press, 1992) 110.

${ }^{13}$ Fraser, op. cit. 115.

${ }^{14}$ Fraser, op. cit. 126.

${ }^{15}$ Malcolm Miles, Urban Avant Gardes: Art, Architecture and Change. (New York: Routledge, 2004) 173-4. 
${ }^{16}$ Ibid. 173-4.

${ }^{17}$ Rosalyn Deutsche, Evictions: Art and Spatial Politics. (Cambridge: The MIT Press. 1996) 322. In reference to Thomas Keenan's notion of the Phantom Public Sphere.

${ }^{18}$ Mitchell op. cit. 148.

${ }^{19}$ Ibid. 289.

${ }^{20}$ Rosalyn Deutsche, "Alternative Space”, Ed. Brian Wallis,. If You Lived Here: The City in Art, Theory, and Social Activism (Seattle, Washington, 1991) 60.

${ }^{21}$ Ernesto Laclau and Chantal Mouffe: Hegemony and Socialist Strategy: Towards a Radical Democratic Politics (London:Verso, 1985)

${ }^{22}$ Deutsche op. cit. 273.

${ }^{23}$ Deutsche op. cit. 326.

${ }^{24}$ Rosalyn Deutsche, Evictions: Art and Spatial Politics. (Cambridge: The MIT Press. 1996) 319. Lippman believed that the public is a phantom because of the impossibility of attaining a unified democratic ideal to supervise the state. Therefore, because of the public's lack of knowledge regarding all issues pertaining to the common good, Lippman proposed that the tasks of the government should be relegated to educated social elites.

25 Ibid. 320 .

${ }^{26}$ Bruce Robbins, "Introduction: The Public as Phantom", The Phantom Public Sphere (Minneapolis: University of Minnesota Press, 1993), xvii.

${ }^{27}$ Deutsche op.cit. 322.

${ }^{28}$ Ibid. 323.

${ }^{29}$ Ibid. 324.

${ }^{30}$ Ibid. 325.

${ }^{31}$ Ibid. 327.

${ }^{32}$ Patricia Phillips, "Public Art: A Renewable Resource”. Ed. Miles, Malcolm. Urban Avant Gardes: Art, Architecture and Change (New York: Routledge, 2004) 122.

33 Ibid.131. 
${ }^{34}$ Rosalyn Deutsche, "Alternative Space", Ed. Brian Wallis,. If You Lived Here: The City in Art, Theory, and Social Activism (Seattle, Washington, 1991) 55.

${ }^{35}$ Ibid. 65. 


\section{From City to Suburb:}

\section{Unification and Fragmentation of Urban Space}

"There must be some way of life where there is no antagonism between the more developed and the less developed - or even between the 'rich and the poor'."

Frank Lloyd Wright, "Architecture and Modern Life" (1937)

From its offices come the commands that put the world in order. In fact, the skyscrapers are the brain of the City...They embody the work of elaboration and command on which all activities depend..."

Le Corbusier,

"Towards a New Architecture" (1960) ${ }^{2}$ 

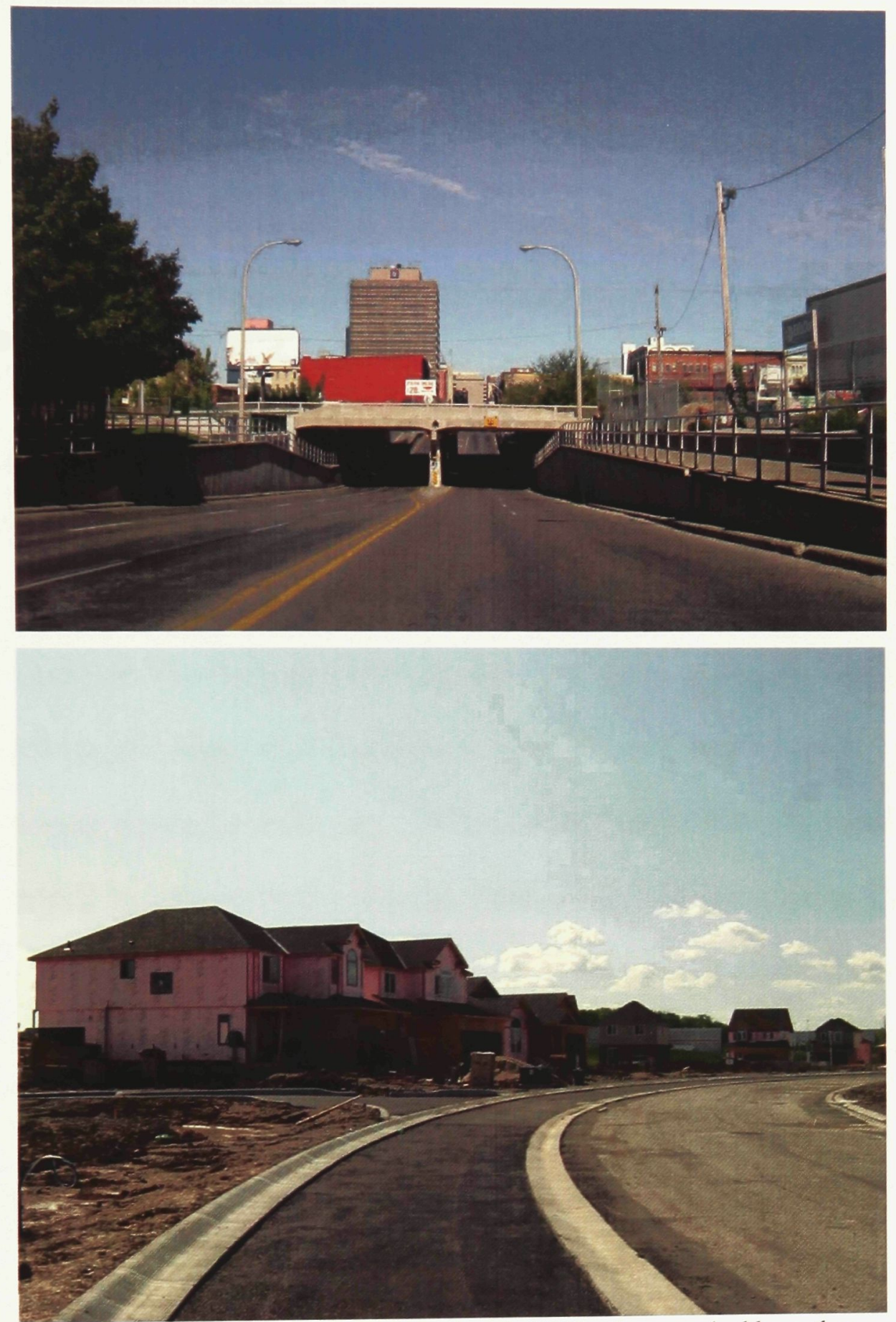

3: City to Suburb, London, Ontario 2006, photographed by author. 


\section{City and Suburb: Constructing a Divided Landscape}

During the early eighteenth century, the rural English countryside was transformed into an idealized setting for middle-class citizens to escape from the speculated congestion and sickness of city centers. Characterized by its reaction against the Enlightenment, the Romantic Movement emerged partly as a way of masking the social realities of the Industrial Revolution, partly as endorsement of the resulting accumulation of capital in the hands of individuals. ${ }^{3}$

The land ordinance grid that was used in the eighteenth and nineteenth centuries for many cities and towns for their efficient and orderly planning gradually resulted in congestion, pollution, crime and disconnectedness from the increasingly valued landscape ${ }^{4}$ European Romantic artists and intellectuals during the mid-nineteenth century incorporated the idea of rural living that encouraged domesticity, privacy and isolation in opposition to the city grid. Architecturally, the effect of Romanticism on the organization of the city was firmly rooted in a particular kind of spatial domain that included a literal and metaphorical connection to the countryside, the domestication of wilderness and the cultivation of the landscape. ${ }^{5}$ Literary artists and painters popularized an idealized view of nature that replaced earlier conceptions of a hostile and dangerous natural world. The "picturesque" aesthetic was an idealized view of nature that was as much a fashionably constructed landscape as the city itself. This picturesque landscape translated aesthetically into the contemporary suburban metropolises. The primary design language that was common in the idealization of picturesque Garden Cities were appropriated into new suburbs as curving streets and park-like scenery. ${ }^{6}$ 
Across North America the Romantic and picturesque ideologies were embraced, eventually producing a conceptualization of the "single-family" dwelling. ${ }^{7}$ The shift in the role of land in daily life also provided an impetus for the consumption of rural property by the middle-class. The growth of commercial agriculture meant that there was no longer any need to grow garden products for food, thereby contributing to a less utilitarian view of the land. ${ }^{8}$ The decision of the middle-class to flee the urban core decisively altered the form of the city. The barrier between the middle and lower-class citizens led to a social distancing that translated into physical form that defined the urban and suburban environments.

In 1853 a planned suburb, Llewellyn Park, named after New York drug merchant Llewellyn Solomon Haskell, was developed. Conceived as a picturesque assemblage of residences standing on broad avenues and winding streets, the strictly residential area precluded the presence of industry and commerce in its vicinity. Although geographically remote from the parent city of Manhattan, Llewellyn Park's Americanized suburban morphology differed from its English counterparts since it was not merely an extension of the city but rather a city in itself. Llewellyn Park was created for professionals who could afford its leisurely lifestyle in an exclusive enclave inhabited by people of similar social and economic backgrounds. ${ }^{9}$

In the years following the American Civil War, several factors contributed to the expansion and availability of residential suburbs to a growing portion of the population. Cheaper and more durable residential construction methods became available. ${ }^{10}$ Stimulated by decreasing land values and expansion of public utilities to support new 
homes on the periphery of the city, the residential suburb was becoming a more popular alternative to living in the city itself.
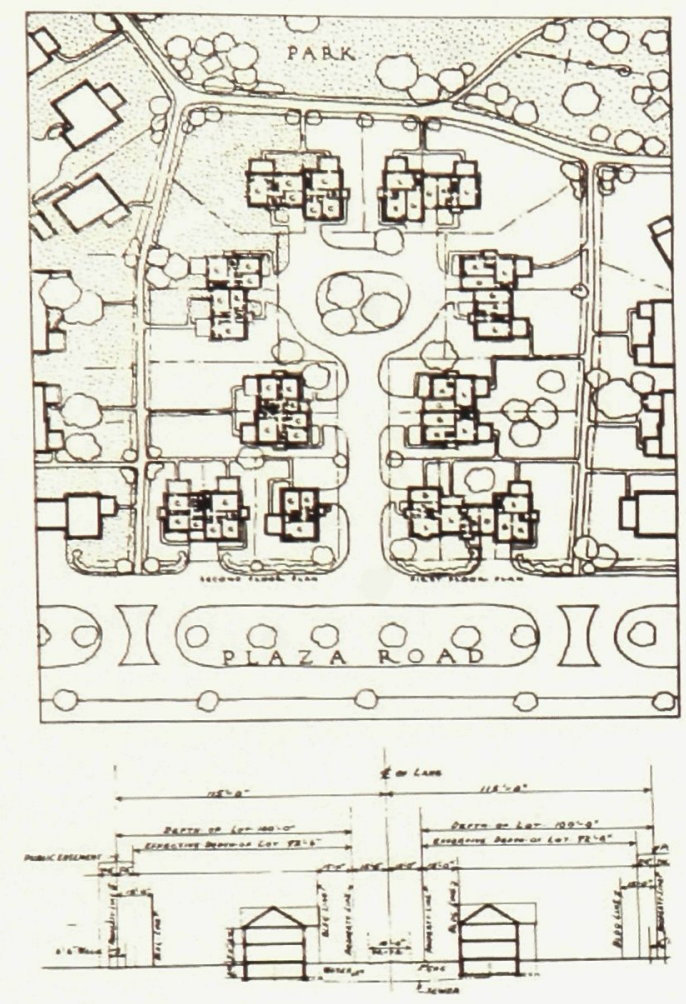

4: Radburn, New Jersey by Clarence Stein and Henry Wright, 1928 from Peter G. Rowe, Making a Middle Landscape (Cambridge: The MIT Press. 1991) 219.

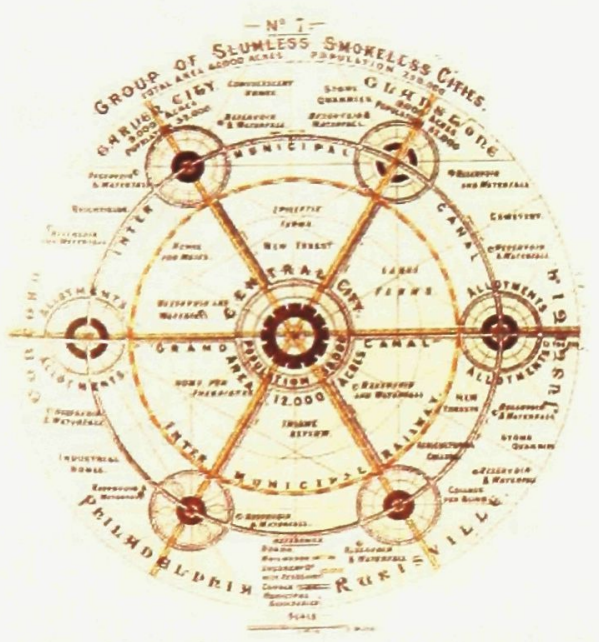

5: Garden City Plan by Ebenezer Howard, from William J.R. Curtis, Modern Architecture Since 1900 (London: Phaidon Press Limited. 1996)
The early twentieth century was a period when the growth rate of the suburbs in the United States gradually increased. Suburbs were growing in both size and distance from major city centers. The popularity of the automobile, the extension and modification of road systems and the romanticization of the rural landscape were important factors that influenced the decentralization of new residential suburbs. Mobility was important to the newly industrialized cities, and circulation had a major impact on its form. Improved systems of transportation across the United States became the precursor of middle-class people flocking to the suburbs, which became increasingly popular after 1920..$^{11}$

Existing hierarchies between institutions disintegrated as industrialization changed the size, shape and relationship of buildings in the cityscape. This disruption of the pre-existing conventions of representation was a major turning point in the eventual proliferation of what came to be known as 
the "urban sprawl." City planning initiatives such as the influential Radburn, New Jersey model of Clarence Stein and Henry Wright, developed in1928, changed the way in which residential and industrial organization was approached. Stein and Wright had a vision that derived from nostalgia for the pre-industrial world. ${ }^{12}$ Based on proposals made by Ebenezer Howard's concentric Garden Cities concept, local communities developed outside the central city core and were supplemented by additional amenities like roadways and small-scale commercial industry. ${ }^{13}$ The construction of secondary streets, parks and pedestrian pathways removed from the main streets created an integrated living condition that combined the automobile with the landscape. An intermediate form between garden city and satellite town, suburbs such as Radburn, New Jersey, became a metaphor of the bourgeois ideals and a model for city planners to emulate.

\section{Modernism and the Absolute: Transparent Urbanism}

As an alternative to the Romantic conception of the city, the search for new ways of life basic to modern architecture of the 1920's involved the desire to synthesize mechanization, geometrical order and 'nature' through the purging of 'slums' and the elimination of the contradictions of the past. ${ }^{14}$ Already underway in Europe, modernism became a dominant approach in the development of cities in the United States. European architects such as Le Corbusier glorified the automobile and the industrialization of the city to counter the prevailing image of modern cities as poverty-stricken urban environments. The complexity of these newly industrialized cities made it difficult for housing to be seen as an element in a larger network of social and economic 
relationships. A strong believer in centralized technocracy and classical urbanism, Le Corbusier attempted to find a singular harmonizing theorem for all of the processes of industrial society. He defended the concept of tabula rasa in the urban core, stating “...that the centres of our great cities must be pulled down and rebuilt, and that the wretched existing belts of suburbs must be abolished and carried further out...". 15

\section{Le Corbusier's proposal for the Contemporary City for 3 Million Inhabitants} embodied both the universalization of city space and a generalized hypothesis of the modern city. In response to the drastic housing shortages and the segregation of economic classes, he proposed plans for Paris that provided a new organizational solution to raise the quality of life of the lower classes.

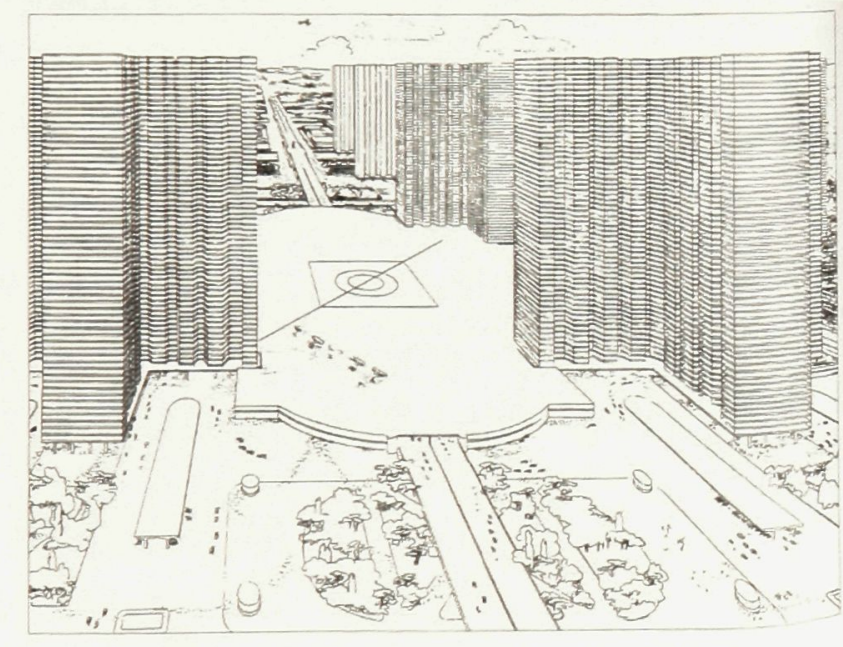

6: Le Corbusier, Contemporary City for 3 Million Inhabitants, 1922, with glazed skyscrapers and multilevel transport terminal at the city centre from William J.R. Curtis, Modern Architecture Since 1900 (London: Phaidon Press Limited. 1996).
The proliferating construction of new industrial buildings in the modern city upset the traditional balance of values. Private buildings reserved for trade, warehouses, factories and eventually offices towered above buildings of civic or religious importance. The elimination and over-simplification of conflict that existed between these types of spaces was a method that resulted in the destruction of spaces that had offered relief from the monotony of the modern city. Le Corbusier's attempt to rid it of its perceived sickness and poverty was intended decisively to eliminate urban conflict. His modernist ideology entailed an architectural expression by which 
function was revealed through form and meaning. The creation of linear spatial relationships reflecting a unification of social processes comprised a multiplicity of meanings that could be attained within or between the public and private spheres. Architecturally, this socio-spatial transparency disengaged the idea of heterogeneity between the buildings, their users, and the context. Resistance to modernism increased as the latter became associated with an authoritative approach to design. The methodology of the Modernists proved to be a controversial and undeniably doubtful concept that would harm the general idea of memory and place. ${ }^{16}$ Subsequently, the tenants of the Modernist movement continue to prevail in various forms of social, economic and architectural systems. As a result of the destruction caused by actual and misused methodologies of modernism, a movement began toward an understanding of the people as a homogenous mass, eliminating “ $\ldots$ not only class and social struggles, but also psychological conflicts and contradictions."17 Much of the remnants of Modernism's approach to public space and urban ideology continue to influence contemporary thinking about methodical design and organization aimed at preventing any collision and confrontation.

\section{Frank Lloyd Wright: The Decentralization of the Modern Plan}

"A good plan is the beginning and the end, because every good plan is organic. That means that its development in all directions is inherent and inevitable." 18

Moving away from the idea of the modern centralized city, Frank Lloyd Wright's plans for Broadacre City rejected the idea of a centralized locality or a suburban 
extension of the city-core, calling for a radical separation of the old city concept and a new suburban typology. Like Le Corbusier, Wright believed that industrialization produced the conditions for a harmonious society, and that fundamental to its new form would be the physical restructuring of society. Based on the universal ownership of automobiles and convenient connections made possible by a network of highways, Wright's Broadacre City combined picturesque qualities with progressive political and scientific culture. His new sense of time and space based on the automobile authorized the planning strategy of the grid. Emphasis on the single-family home as the central link of the community gave increased importance to the connectivity of roadways. Wright's anticipation of roadside markets at major intersections anticipated the current-day idea of the shopping centre.

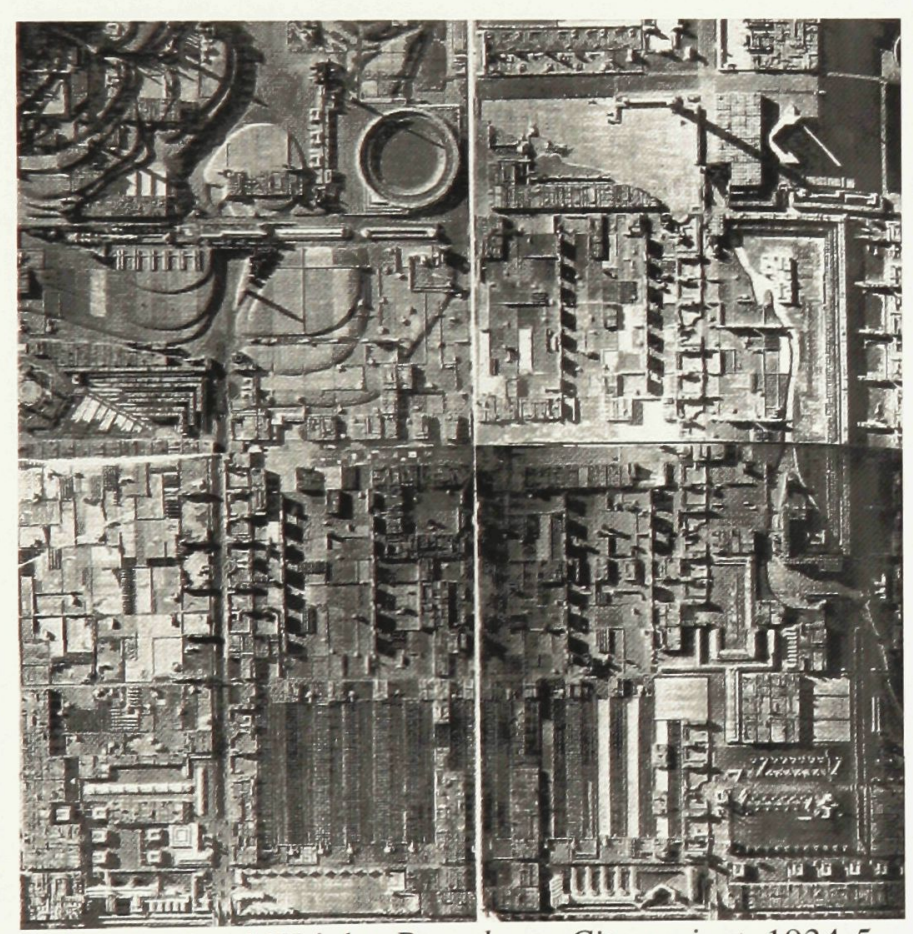

7: Frank Lloyd Wright, Broadacre City project, 1934-5, model from William J.R. Curtis, Modern Architecture Since 1900 (London: Phaidon Press Limited. 1996) 316.
The low-density grid plan would assign an acre of land to each residential unit.

This was supposed to release people from the “...]tyranny of centralized urban capitalism - of rent."19 Wright believed that once the inequities of land ownership were resolved, democracy would be realized. Wright's focus was on the family unit and the democratic freedom of the individual. His plans for Broadacre embodied his avid discontent

with the military which he saw as an enemy of individuality. For Wright the military 
represented a "regimented, dependent, vicarious life, which the feudal economic powers and urban life had forced upon modern man." 20 Thus the notion of a decentralized city subverted the underlying structure necessary for the military's defense mechanism.

Moreover, Broadacre's agrarian-based model also provided a way to endure the impact of a potential war waged against its agrarian-based economy.

Wright's plan for Broadacre City left a significant imprint on the debate of city planning. He described the urban core as a passive, conformist, and mediocre structure dependent on a centralized authority. ${ }^{21}$ Similar to Le Corbusier, Wright sought to eliminate conflict between the public and private realms. Wright believed that conflict could be overcome by focusing the 'true centre' of Broadacre City on the homestead. As an advocate of the power of the individual over imposed institutions, he championed the preservation of individuality, regardless of the consequences for social stability. Latent in Wright's idealization of the democracy of Broadacre City is its similarity to the idea of the "phantom public sphere." The individual is dependent on a stable community, yet his/her freedom to question and to negate is always a potential threat to society. Although similar to democratic ideology spatially the chances of conflict occurring in public space, was restrained by Wright's ultimate goal of unification. Most notably, through his use of an isolated low-density urban planning scheme that focused on the singular and private realm. Interestingly, Wright's democratic ideology would seem fitting for an urbanized morphology rather than a decentralized urban pattern. Sociologist Robert Park argues that the combination of the anonymity of the metropolis, the countless juxtapositions of diverse groups, and the infinite range of human contacts, seems to create the most vibrant and independent environment for a democracy. ${ }^{22}$ While both Le Corbusier and Wright 
recognized the city as the location of a centralized power, their architectural expressions couldn't be more opposite. Le Corbusier advocated the intensification of the efficiency of the urban condition, whereas Wright saw the protection of its autonomy in decentralization. While both attempted to reconcile with 'nature,' the picturesque ideals of Wright's decentralized planning scheme have prevailed, transforming the landscape along the periphery of the contemporary urban environment.

\section{Chapter 2 Notes}

1 Robert Fishman, Urban Utopias in the Twentieth Century (New York: Basic Books Inc. 1977) 145. Taken from Frank Lloyd Wright's, Architecture and Modern Life (New York, 1937) 311.

${ }^{2}$ Fishman, op. cit. 192. Taken from Le Corbusier's Towards a New Architecture, trans. Frederick Etchells (New York, 1960) 102-103. 219.

${ }^{3}$ Peter G. Rowe, Making a Middle Landscape (Cambridge: The MIT Press. 1991)

${ }^{4}$ Howard Frumkin, Lawrence Frank, and Richard Jackson, Urban Sprawl and Public Health: Designing, Planning, and Building for Healthy Communities (Washington: Island Press. 2004) 31.

${ }^{5}$ Ibid. 232.

${ }^{6}$ Robert Fishman, Bourgeoisie Utopias (New York: Basic Books Inc. 1987) 49.

${ }^{7}$ David C. Thorns, Suburbia (London: MacGibbon \& Kee. 1972) 65.

${ }^{8}$ Frumkin op. cit. 29.

${ }^{9}$ Thorns op. cit. 65 .

${ }^{10}$ Howard, Frank and Jackson op. cit. 33.

${ }^{11}$ Thorns op.cit.. 64.

${ }^{12}$ Humphrey Carver, Cities in the Suburbs (Toronto: University of Toronto Press. 1962) 40 . 
${ }^{13}$ William J.R. Curtis, Modern Architecture Since 1900 (London: Phaidon Press Limited. 1996) 243. The social criticism at the time when Howard was developing his ideas was heavily influenced by the writings of John Ruskin. Ruskin celebrated the idea of 'clean streets with free countryside all around; a belt of fine gardens and orchards, so that from every point in the city one can reach the pure air, the grass and the distant horizon". Howard's romantic vision of inhabitation evolved with post-Garden City planners where the introduction of necessary modes of efficiency paralleled that of a growing economy.

${ }^{14}$ William J.R. Curtis, Modern Architecture: since 1900 (London: Phaidon Press Ltd., 2001) 241.

${ }^{15}$ Malcolm Miles, Art, Space and the City. (New York: Routledge, 1997) 27.

${ }^{16}$ Anthony Vidler,. The Architectural Uncanny. (Cambridge: MIT Press., 1992) 180.

${ }^{17}$ Marshall Berman,. All That Is Solid Melts Into Air: The Experience of Modernity (New York: Simon and Schuster, 1982) 28-9.

${ }^{18}$ Frank Lloyd Wright,. "in the Cause of Architecture: the Logic of the Plan". Architectural Record, vol. 43, no.1 (Jan. 1928). 49.

${ }^{19}$ Curtis op. cit. 316.

${ }^{20}$ Robert Fishman, Urban Utopias in the Twentieth Century: Ebenezer Howard, Frank Lloyd Wright, and Le Corbusier. (New York: Basic Books, Inc. 1977).149.

${ }^{21}$ Ibid. 153.

22 Ibid. 159. 


\section{3 \\ The City In-between:}

Contemporary Suburban Landscapes

"The Generic City, like a sketch which is never elaborated, is not improved but abandoned. The idea of layering, intensification, completion are alien to it...the Generic City perpetuates its own amnesia...Its archaeology will therefore be the evidence of its progressive forgetting, the documentation of its evaporation."

Rem Koolhaas,

“S, M, L, XL” (1995) ${ }^{1}$ 

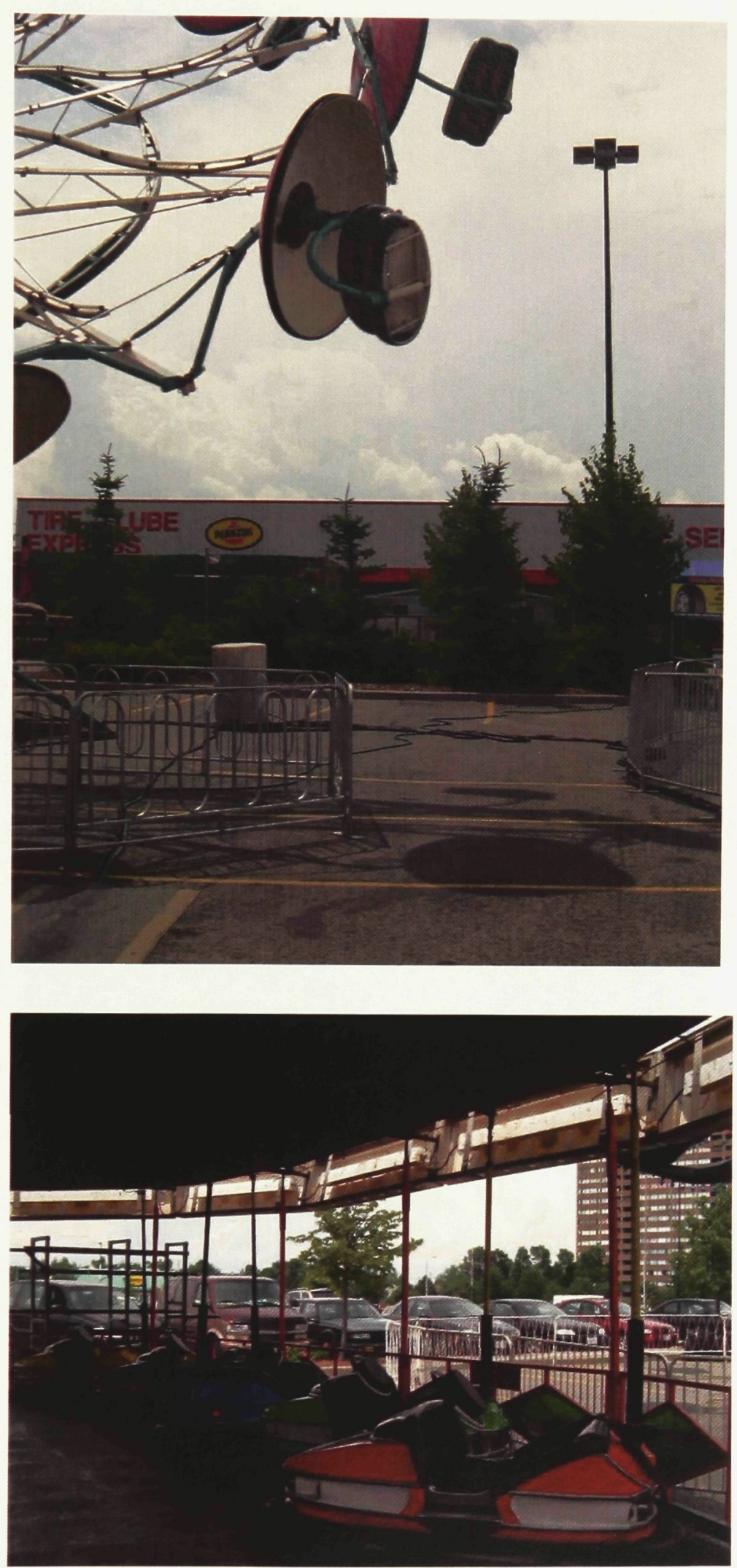

8: (bumper) Cars, 2006, photographs by author. 

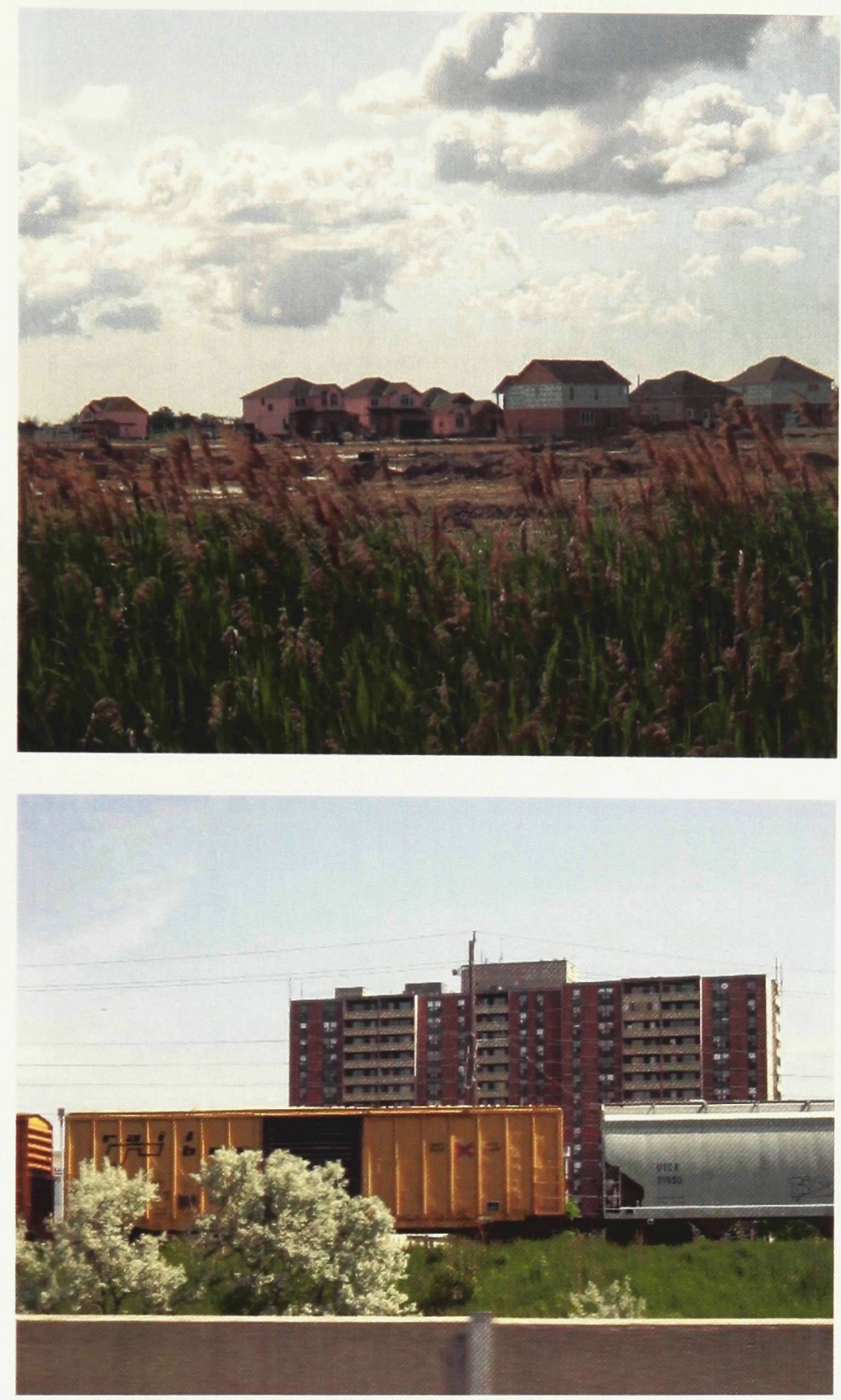

9: City, Rail \& Road, 2006, photographed by author. 

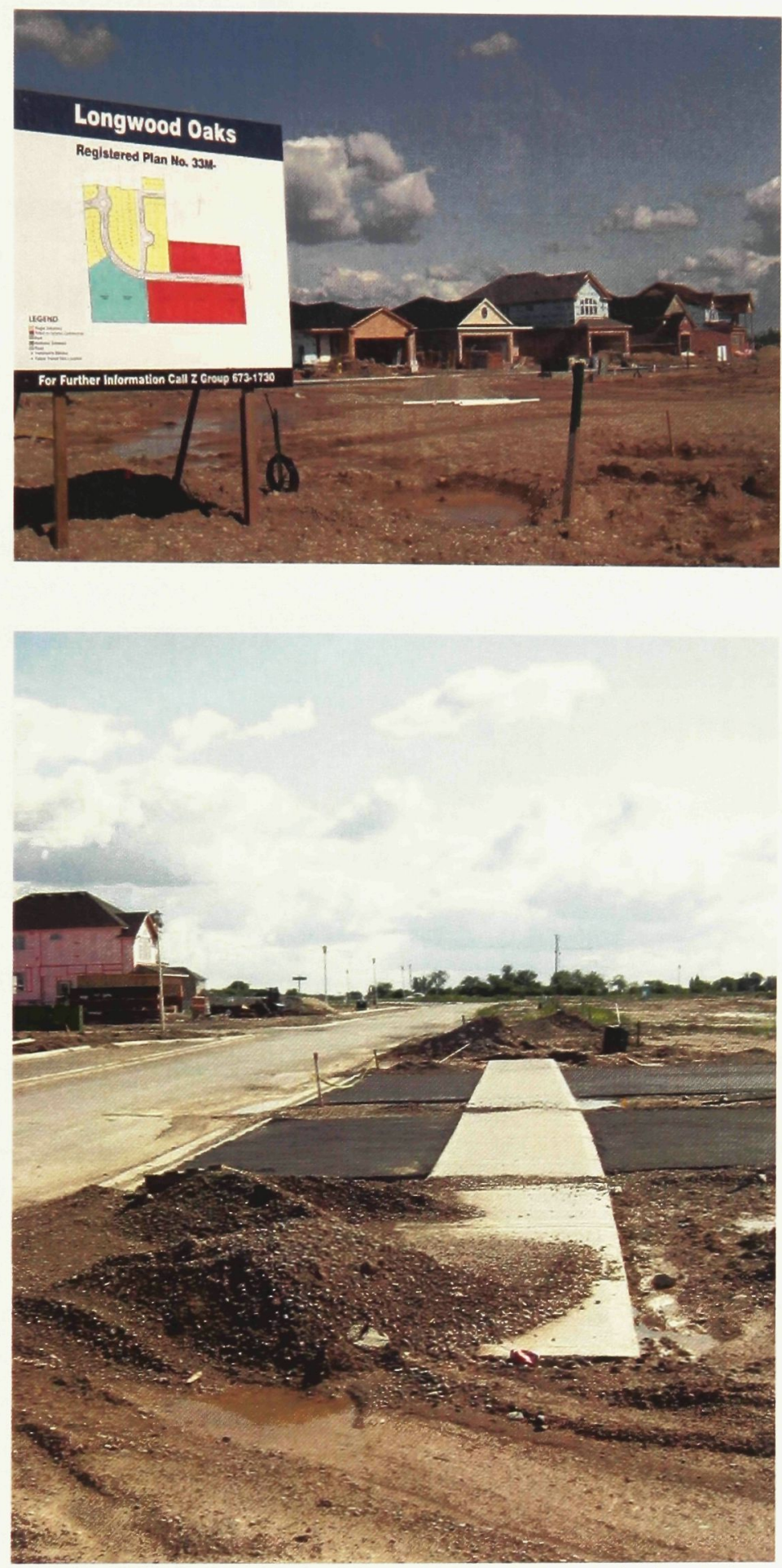

10: Nature Rebuilding, 2006, photographs by author. 


\section{$\underline{\text { The City In-between: Contemporary Suburban Morphology }}$}

Modernism's subsequent movement towards the periphery of the city implied not only a quantitative but a qualitative cultural change. The acknowledgment of Modernity's limitations was a strong theme which generated new ideas about the organization and representation of post-modern contemporary suburbs. In his book After the City, Lars Lerup supports Gianni Vattimo's criticism of modernity which describes the city as becoming "used to architecture that is no longer the instrument of the city form.",

The discourse on the space between nature and artifice underwent a transformation which impacted socio-spatial and geographical realms of the city, one that assumed a division between city and suburb. New patterns of living for an increased uniformity in the American lifestyle were dedicated to the development of a decentralized environment. Unlike the English suburbs of the picturesque period that preserved the unity between the urban core and the suburb, the creation of its American postwar counterpart possesses all the economic and technological dynamism we associate with the city. The post-modern city was described by Anthony Vidler as a "culture where suburb, strip and urban center have merged indistinguishably into a series of states of mind". His account of the suburban realm includes the monotonous repetition of sameness and movement, across "vanished thresholds" that barely give reference to their former function.

Many attempts have been made to define this continuously expanding landscape between the rural and the central city core, but it remains indeterminate due to the ongoing development of new relationships and organizations. An assortment of terms has 
been applied to these new suburban metropolises such as "exurbia", "exopolis", "middle landscape", "ethnoburb", "technoburb", etc. This thesis prefers the term (sub)Urban. The bracketed prefix suggests that the traditional idea of the suburb is no longer fully intact, yet it implies the memory of its past physical demarcations, organizations, and social relationships. The emphasis on the urban refers to the intensification of building that these decentralized cities have undergone. Furthermore in both prefix and noun, 'sub' meaning below, under, or beneath while 'urb' is understood as an urban area, relate to the methodology and ideation in the design proposal of the thesis. The ambiguity of the prefix allows for the idea of the new suburban cities to remain in a constant flux between downtown and suburb and to maintain a relationship that allows the suburb to exist within the seams of the city.

\section{Mobility and the (sub)Urb}

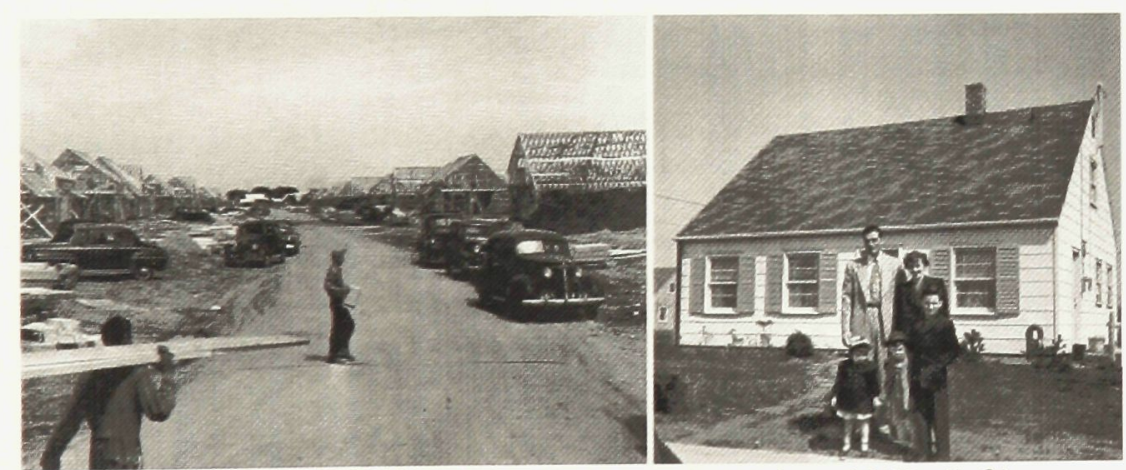

11: (right) Levittown, New York under construction, 1950, (left) Levittowners infront of their home, 1948, Peter G. Rowe, Making a Middle Landscape (Cambridge: The MIT Press. 1991) 51-52.

\author{
Beginning in the \\ 1950’s the desire for \\ private single-family \\ housing resulted in the \\ construction of "bedroom \\ communities' such as \\ Levittown, Pennsylvania.
}

These middle-class residential suburbs were often seen as the archetype of suburbia that has contributed to the development of the popular stereotype of the suburb and the 
suburban way of life. Characterized by the collective attempt to lead a private life and by creating new institutions to meet the needs of the inhabitants, this type of suburb provided the people with a new way of life much different from its urban counterpart. Levittown began as a relatively modest venture of providing about 2, 000 houses to be rented to servicemen returning from World War II. As the demand for cheaper land and privacy increased, the number of houses in Levittown grew to nearly 15,000 by $1951{ }^{4}$ Originally built as a residential community, it later integrated institutional buildings and other commercial services into its plan. There was an element of self-containment to Levittown both for the purpose of minimizing uncertain speculative contact with adjacent developments and in order to create a strong sense of community identity.

Many other communities built after Levittown had the intention of maintaining a relationship with their urban core by providing middle class families with affordable housing. The proliferation of the automobile intensified the presence of the basic conditions for classic suburbanization. According to Robert Fishman in Bourgeois Utopias: The rise and Fall of Suburbia, the proliferation of cars, and an abandonment of reliance on public transportation occurred. ${ }^{5}$ In the suburban metropolis, the integration of different programs is achieved largely though horizontal aggregation of land parcels. Consequently, functional integration is largely a matter of spatial juxtaposition next to, adjacent to, or across from other kinds of institutions. This type of formation places emphasis on minimizing outside influence and maintaining a distinct internal atmosphere by creating enclaves of single-use areas.

These (sub)Urban cities have seen a transformation from the metropolitan city to a more specific multi-functional suburban metropolis. They exist as a recombination of 
urban characteristics at a lower density, while possessing the ability to attract industry and commerce from the core, reducing the distinction between center and periphery. The current fabric of the city that defines this new urbanity is not organized in oppositional terms such as center vs. periphery, but as a multi-centered non-hierarchical urbanized territory. ${ }^{6}$ Michel de Certeau, in his book The Practice of Everyday Life, speculates that this "in-between" territory appears as a historical layering of demographic and economic shifts, but is in fact more like an accumulation of dissociated heterogeneous places. De Certeau explains that each place refers to "a different mode of territorial unity, of socioeconomic distribution, of political conflicts and of identifying symbolism."7 Moreover, because these modes are fragmentary, they possess only some of their original function or meaning. Their tendency to decentralize nonresidential activities results in outlying populations that sever direct ties to the central city. This organizational structure gives rise to self-acting urban systems that are independent of the parent city, yet duplicative in function.

The intensification of suburbia is conceived of as a fully autonomous entity which yields itself to a fragmented urban landscape that bares little resemblance to the urban organization from which it originated. Oliver Gillham, in The Limitless City ${ }^{8}$, provides an accurate description of sprawl by relating its formation to "leapfrog patterns of development, commercial strips, low density, separated land uses, automobile dominance, and a minimum of public open space." Gillham's observations are precise and thorough, but lack the adversary significance that suburban sprawl implies. Lars Lerup claims, in After the City, that the “...internal nature of the sprawl unit is both rudimentary and crude, and in need of evolution. The orientation of the house is totally 
dependent on the platting, with no regard for the compass, the landscape, or prevailing ecology. Inefficient and wasteful, "sprawl's" true power and success lie in its economic and social effectiveness." 9 He criticizes the ubiquitousness of the (sub)Urbs' components and relationships. Lerup points out that contemporary society is in motion, and suggests that, rather than design structures, the solution is to design meaningful spaces for bodies in motion, places to be for "a world where being means being in motion." ${ }^{10}$ Motion for Lerup corresponds to Thomas Keenan's transient and illusory public sphere. The idea of time-space relationship suggests more than just the movement created by technology; rather it is a constant fluctuation taking place in the socio-political field.

\section{Public Space in the (sub)Urbs}

The fragmentation of the suburban metropolis has manipulated and changed the way the public sphere operates. No longer is the plaza the public space of the city. The new (sub)Urban territory will depend on its unpredictably dynamic nature that is bound to events rather than manifested by places. In a statement made in the New Jersey Supreme Court, Chief Justice Robert N. Wilentz said:

"Shopping malls have replaced the parks and squares that were 'traditionally the home of free speech'... The economic lifeblood once found downtown has moved to suburban shopping centers, which have substantially displaced the downtown business districts as the centers of commercial and social activity...". 11

Abundantly evident is that the morphological functions of the suburbs have changed significantly from their previous mono-functional composition, the socio- 
cultural aspects of their development have not. The social synthesis of an urban situation is one that constitutes the complexity of its context due in part to the dense mixed-use multi-cultural dwellings, whereas in a suburban situation social heterogeneity exists in what appears to be a serially linked relationship which manifests itself across a vast and transparent network. Peter Marcuse criticized the creation of a suburban periphery with respect to urban planning practices and concluded that new suburban strategies were an inversion of those applied by the Modernists. ${ }^{12}$ The Modernist goal to introduce a new organizational structure on what they perceived as chaos found new meaning in the suburbs. In the suburbs, an entirely opposite relationship occurred where infinite and winding streets were superimposed on an ordered structure. This chaotic organization defines itself as an interruption in the hierarchical relationships between people and the ordering principles of their suburban space. Marcuse sees this interruption as a forceful way of imposing diversity and heterogeneity on a space that used to be a reactionary strategy in the urban setting. ${ }^{13}$ This sense of diversification in the suburbs is reinforced by the cultural consumption of media and material objects which promotes the community as a product rather than the community as a place.

Ignasi Sola-Morales feels that the need to determine a more precise distinction about the "public vs. private" paradigm could be achieved by viewing it as a phenomenon of "collective space". ${ }^{14}$ Collective spaces are meeting places in the city that, though privately owned, are capable of offering a backdrop for various public activities and events. Such places do not always have extraordinary programs and are sometimes encountered on a daily basis. Examples of such programs are the shopping mall, the sports arena, or a theme park. Sola-Morales views collective space as architectonic, 
urbanistic and morphological resources of the city. When utilized by its participants, the collective space is able to be activated and unfolded within the context of everyday life, to give the space an identity and memory. They are neither exclusively private nor public, but exist as an indivisible entity that would permit the actions on a both private and public basis. The categorical distinction between public and private would no longer suffice. ${ }^{15}$ Sola-Morales' investigation offers insight of the public body by addressing recurrent issues of public and privatized space. Most prominent and debated are examples of the appropriation of public space by private institutions or special interest groups that own the shopping mall. Unfortunately, the paradox created in the dissolution of SolaMorales' collective space delicately tiptoes around issues related to controlled privatized space that implies its inescapable exclusion for a specific notion of public use or purpose. Public and pseudo-public spaces perform a vital role in representational politics. The overriding purpose of public space becomes the creation of a deliberately shaped 'public'. The people eligible to perform in these controlled public spaces is confined to a specific idea of public that will project an appropriate image for the institution.

The disparity found in the suburban shopping center's conception as a public space is fundamental to its function. While supposedly unbiased and open to a variety of social groups, it remains intolerant towards impromptu entertainment. The mall is a controlled public realm that confines its users to a zone exclusively oriented towards consumption. The creation of divided public and private realms means that the public and private realms decisively remain socially, economically and politically uneven. In this way, the public space of the shopping centre acts in a similar way as the bourgeois public space described by Jurgen Habermas. 


\section{Media and the (sub)Urban Public Sphere}

Media consumption and material consumption are compounded by the suburbs' lack of symbolic structure which normally signifies the central city, such as skyscrapers and subways, but it is able to maintain a singular enduring component: the idea of the individual 'family' unit. For the suburbs this component is crucial in understanding the changes that ensued in the social sphere. The diversity of demographics in the (sub)Urb has developed from major cultural shifts which include recognition of differences in the traditional definition of the nuclear family, an increase in ethnic and economic diversity and the reorientation of a private social life.

Social life as encountered in the urban condition typically stems from events that take place on the street. There the public and private realms are commonly engaged into a complex network of events and modes of interaction. In a typical (sub)Urban organization social events are concentrated around familial activities and private institutions. Throughout history, urban space has been inevitably intertwined with the city, beginning with the ancient Greek polis. This formed the representation of a political system in which the public domain played an important role. Typically the character of these historical cities was demarcated by buildings which integrated public functions and which also created various kinds of venues for public interaction. Currently, we are faced with different types of public realm in the suburbs which disregards the material urban space of public life that was once tied to the concept of the "civic" city. Marc Auge points out that "... public space has often become no more than a transitional space ... 
[where] new communication technologies have not been responsible [only] for a virtualization of the public domain: [arguably] they have also weakened the ties between individuals and society and stimulated various forms of homeliness and cocooning."16 The television assumes the critical cultural and ideological functions of representation by replacing family life. Collectively, the television and the car work to re-establish the connection lost by the movement away from the downtown. The car has acted as an extension of the house into the city, while the television has brought the city and all its related events into the house. ${ }^{17}$ The television inverts the idea of a civic public by confining it to the limits of the individual home. The transformation of the public domain to an internalized condition has dramatically changed the way in which we experience communication with others.

The amalgamation of computer and television, merged with social communication, has blurred the lines between the public and private environments. Television is a primary medium, standard in most residences, therefore imagined interactions with television characters and images allow one to identify with or incorporate the televised characteristics into one's own identity. ${ }^{18}$ The isolated decentralization and segregation of the public realm resulted in the individual interpretation of a public sphere. Communication is conducted through an abstract medium which may be subject to interpretation and could be misconstrued. Confusion amongst the private and public realms is demonstrated in situations where the experience of an environment is similar to something that is represented through the media. It slowly becomes impossible to tell which 'reality' serves as the original template: the lived space or the projected space contained in the television. 
For example, the Canadian-produced cartoon 6Teen follows the lives of a group of teenagers who work, lie around and shop at their local mall. "Each character is tailored to resemble a range of subcultures or subtypes of teenagers... and targets issues that teens deal with on a daily basis, while still remaining entertaining. The result is that the teenage target audience can relate to the characters and their lives at the mall."19 The assumption that the general audience can identify with these types of characters suggests that it is an accurate depiction of suburban culture. ${ }^{20}$ Moreover, it implies that it is an ideal lifestyle to aspire to. 6Teen illustrates the suburban notion of contemporary adolescent culture but it leaves the public in a state of uncertainty about whether its representation is a critique or reinforcement of these notions of socio-cultural interactions in the lives of suburban teenagers. Dependence on the media for cues to identifying with a particular lifestyle has become a familiar mode of representation in the (sub)Urbs. 


\section{Chapter 3 Notes}

${ }^{1}$ Rem Koolhaas, S,M,L,XL (New York: Monacelli Press., 1995) 1263.

${ }^{2}$ Lars Lerup, After the City (Cambridge: The MIT Press. 2000) 22.

${ }^{3}$ Yorgos Simeoforidis, "The Challenge of the Critical Landscape", The critical Landscape. Ed. Michael Speaks (Rotterdam: 010 Publishers, 1996) 203. 50.

${ }^{4}$ Peter G. Rowe, Making a Middle Landscape (Cambridge: The MIT Press. 1991)

${ }^{5}$ GUST: The Ghent Urban Studies Team, The Urban Condition: Space, Community and the Self in the Contemporary Metropolis (Rotterdam: 010 Publishers 1999) 19.

${ }^{6}$ Mario, Gandelsonas, X-urbanism: Architecture and the American City (New York : Princeton Architectural Press, 1999) 32.

${ }^{7}$ Michel De Certeau, The Practice of Everyday Life, trans. Steven F. Rendall (Berkeley: University of California Press, 1984) 201.

${ }^{8}$ Oliver Gillham, The Lmitless City: A Primer on the Urban Sprawl Debate (Washington: Island Press, 2002) 8.

${ }^{9}$ Lerup op. cit. 54.

${ }^{10}$ Ibid. 174.

11 Tae-Wook Cha, Chuihua Judy Chung, Jutiki Gunter, et. Al. "Shopping", Mutations: A Harvard Project on the City ed. Armelle Lavalou (Barcelona: ACTAR, 2001) 154 .

12 GUST: The Ghent Urban Studies Team 71.

${ }^{13}$ Ibid. 71.

${ }^{14}$ Ibid. 90.

15 Ibid. 91.

16 Ibid. 89.

${ }^{17}$ Gandelsonas op. cit. 31. 
${ }^{18}$ Langman op. cit. 55.

${ }^{19}$ Wikipedia, "6teen" <http://en.wikipedia.org/wiki/6teen>.

${ }^{20}$ Wikipedia, "6teen" <http://en.wikipedia.org/wiki/6teen>. 


\section{$4_{\text {Consuming Space: }}$}

The 'Mallification' of the (sub)Urb

"Shopping centers have taken on the characteristics of urban organisms serving a multitude of human needs and activities, thus justifying the designation: Shopping Towns."

Victor Gruen,

"Shopping Towns USA: The Planning of Shopping Centers" $(1960)^{1}$ 

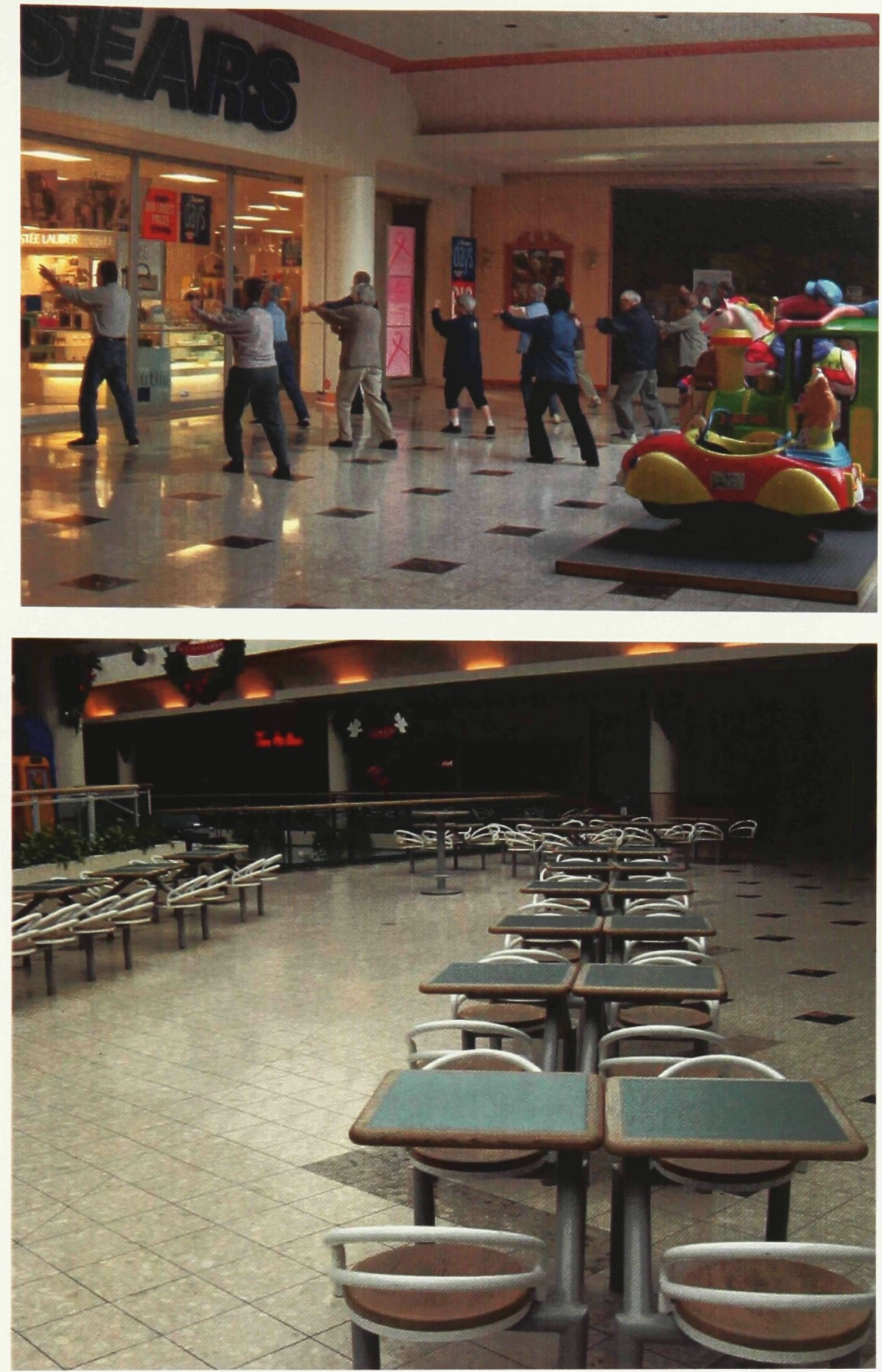

12: Early morning Tai Chi, 2006, Westmount Mall, photographs by author. 

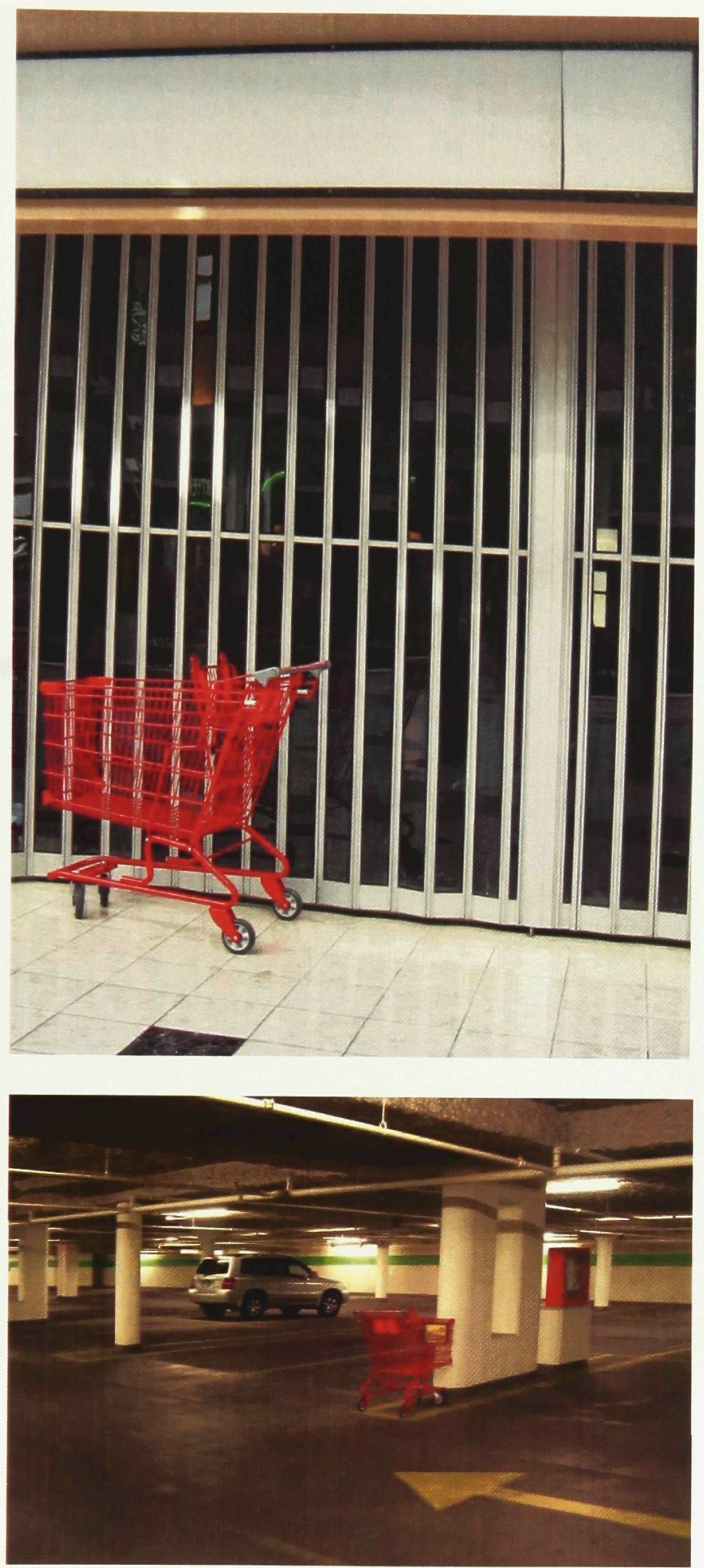

13: Shopping carts, Westmount Mall, 2006, photographs by author. 

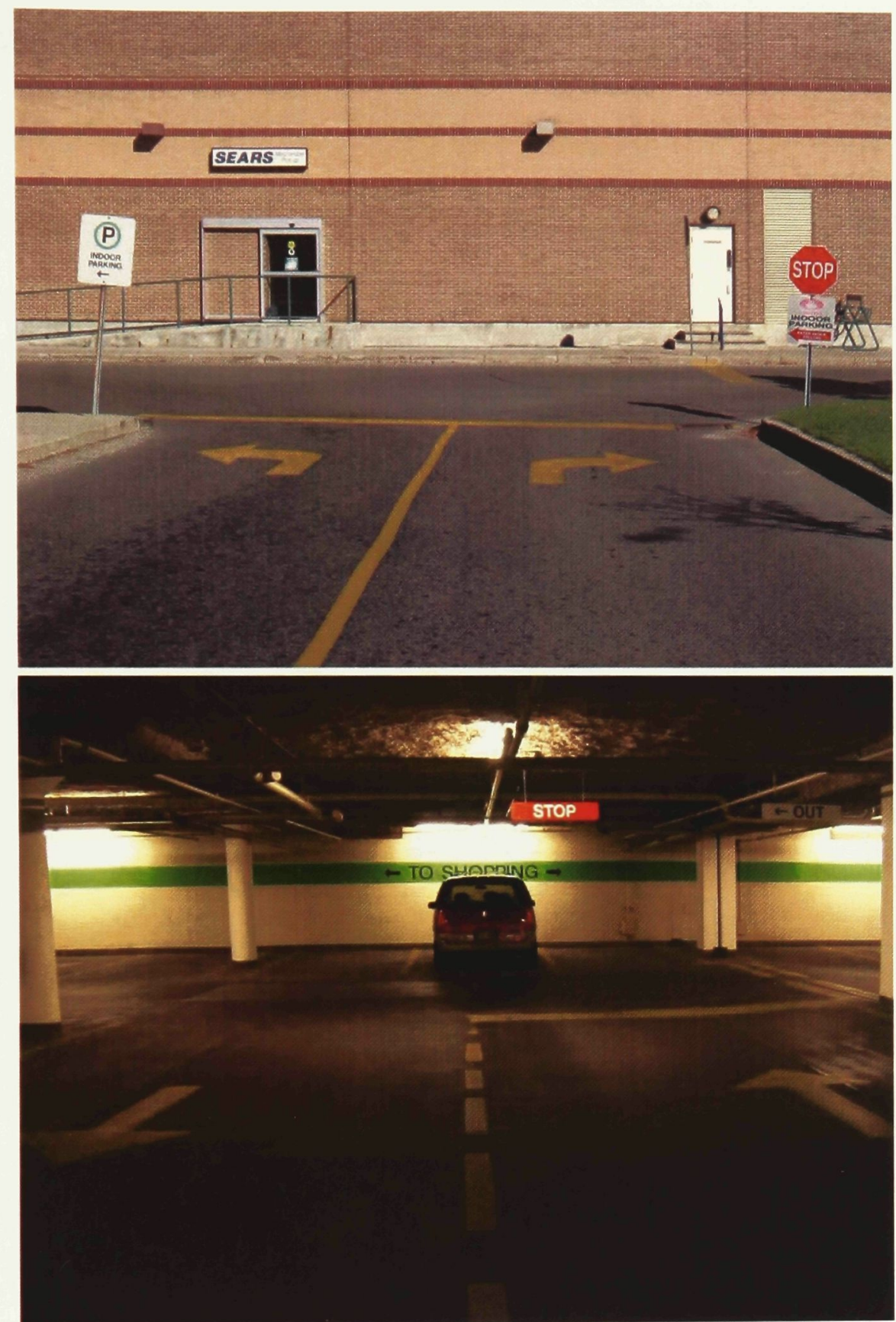

14: Codes of entry, 2006, Westmount Mall, photographs by author. 


\section{Making the Mall: The New Public Realm}

Before World War I, retail commercial activities in a city or town consisted of an agglomeration of small, specialized outlets, with some department stores located in central areas. Ownership was typically independent, and the relationship created between the vendors and their buying public was dependent on the ability of the shopkeeper to physically deliver goods to the consumer. During World War I the mode of shopping changed to accommodate larger volumes of people, and combined a variety of services in a single store, such as a large department or grocery store. By the early 1920's selfservice merchandising was the predominant mode of shopping in the United States. ${ }^{2}$ As residential developments grew, retail goods and services continued to be demanded conveniently close to homes. The phenomenon of locating shopping centers in the midst of a residential development was particularly evident during periods of rapid suburban expansion, when growth appeared to be more or less predictable. ${ }^{3}$ Architecturally, larger and wider expanses of floor space were required in order to display the goods effectively and to accommodate more than one kind of merchandise. Standardization within corporate chain store outlets fixed not only the internal layout and signage but also the building envelope and form, regardless of regional differences or potential local variations or identities. 
During the 1950's and 1960's the scale of retail operations continued to increase with the advancement of the enclosed pedestrian mall, the first of which was developed in suburban Minneapolis by Victor Gruen in 1953. After arriving in the United States in 1938, Austrian-born architect Victor Gruen wanted to forestall the suburban sprawl and the damage he believed the automobile was causing to the social fabric of the suburbs. ${ }^{4}$ His Southdale Mall became an entirely new retail environment for suburbanites with 810,000 square feet of shop space, 5,200 parking spaces, a garden court, and two full sized- department stores. ${ }^{5}$
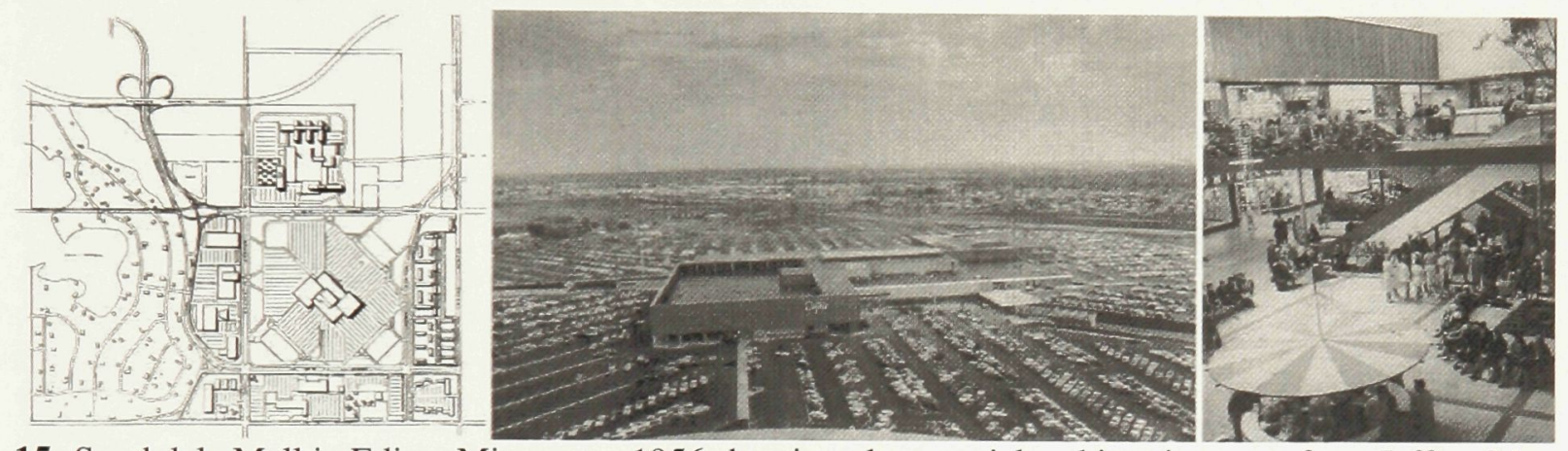

15: Southdale Mall in Edina, Minnesota, 1956 showing plans, aerial and interior court from Jeffrey M. Hardwick, Mall Maker: Victor Gruen, Architect of an American Dream (Philadelphia: University of Pennsylvania Press, 2004) 143-145.

Gruen's new type of retail space tried to equate the roles of shopping centres with the amenities of social life. His model for Southdale was influenced by the Gallerias in Europe, more specifically the Galleria Vittorio Emanuelle in Milan, Italy. This particular Galleria houses four storey arcades and glass barrel vaults that terminate in a giant central glass cupola. ${ }^{6}$ Gruen's simulation of the Galleria enclosure introduced another element of design which was the central court. His idea to commission a sculpture for the court to “... balance and enhance the indoor greenery and appointments ..." was one of the first known occasions of art being specifically created for an American shopping center. ${ }^{7}$ Gruen saw the mall as a place that could counteract the phenomenon of alienation and 
loneliness and achieve a sense of identification and participation. For example, the Southdale Center in Minneapolis was host to events such as concerts by the Minneapolis Symphony among many other manifestations that reinforced a renewal of civic participation. The advent of regional shopping malls brought with it a hierarchy of shopping behaviour that abandoned the central downtown commercial area in favour of a suburban location that could be served by high-speed vehicles running on high-capacity streets.

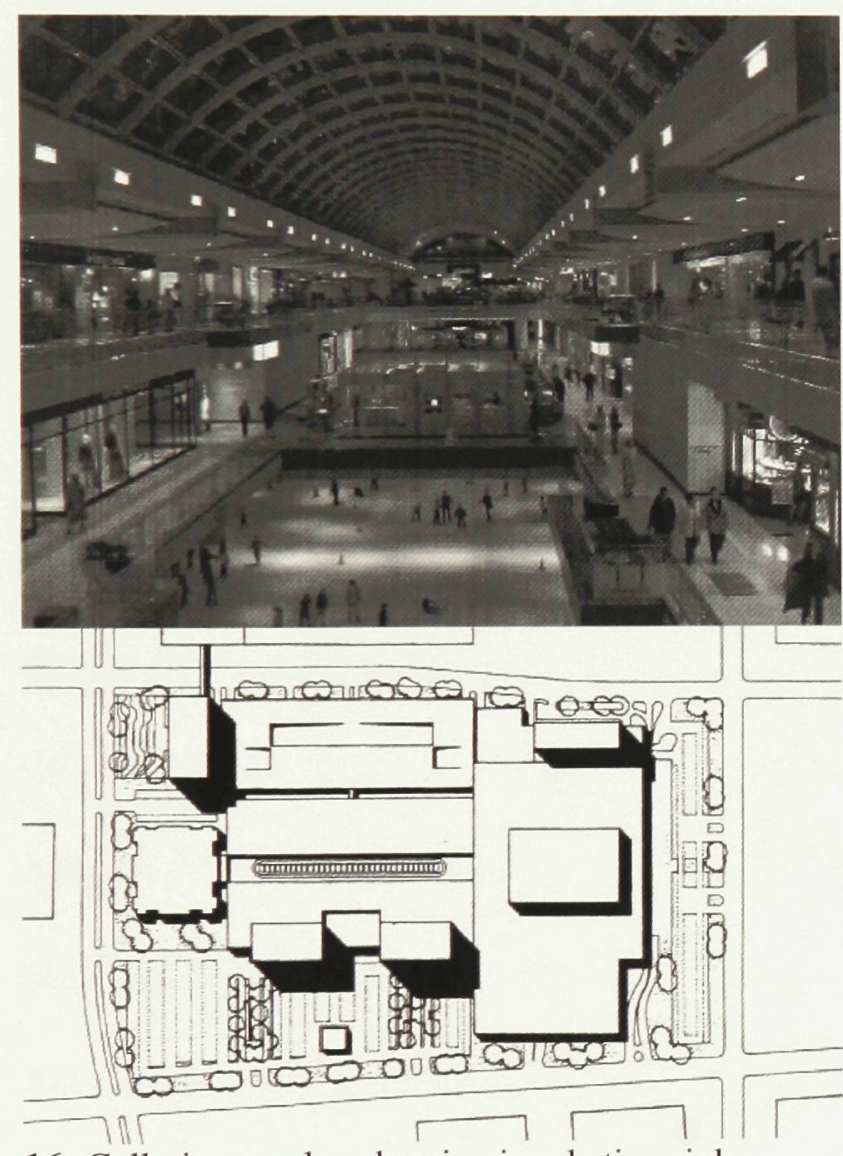

16: Galleria complex showing ice skating rink, Houston Texas, from Peter G. Rowe, Making a Middle Landscape (Cambridge: The MIT Press. 1991) 129.
By the late 1960's, the enclosed pedestrian mall reached a new level of commercial growth in the form of mixeduse developments or 'super-malls'. Situated on of the first malls of this type was the Galleria complex in Houston, Texas, developed by Gerald D. Hines Interests in $1971 .^{8}$ The first phase of the Galleria encompassed 788,000 square feet of retail space, approximately 1 million square feet of office space, a 400-room hotel and a large recreational facility. The total area of the mall after its second phase

put it well over 3 million square feet of facilities located in a single rectangular city block of about 33 acres. Each assemblage of buildings has its own unique character and 


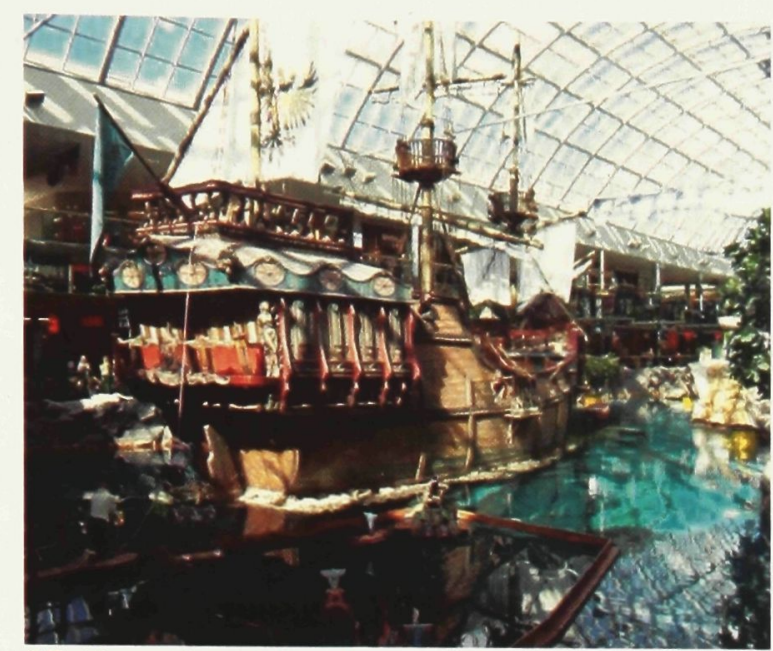

17: Deep Sea Adventure at West Edmonton Mall, Alberta from http://www.cs.ualberta.ca/ acoman/images/cana da/edmonton/100_0103.JPG

identity, which helps define various parts of the complex, and promotes an urban appearance of building façades, forecourts, and sidewalks.

Large consolidations of programs were introduced into more extreme mergers of shopping and recreation. The West Edmonton Mall in Edmonton, Alberta, 19811985, proved that material consumption could become recreation. Designed by Marcie Sunderland, the mega-mall contains over 4 million square feet of retail space and 11 major department stores. Its main pedestrian spine runs the length of the rectangular plan, which is bisected by theme parks and other shopping precincts. The mall's exterior, unlike the Galleria, is essentially inconsequential to the interior. This typological shift has fashioned an entirely interior spatial integration of leisure and shopping. In the West Edmonton Mall traditional civic leisure activities have been transformed into fantastical landscapes. The mall's obtuse materialism and anti-urban disposition seem counter-productive, aside from the fact that these activities have been and continue to be normative events of entertainment of civic life.

The added inclusion of combined programs in suburban malls such as the addition of movie theatres, has served as an attraction and commercial enterprise. The public space of the suburbs exists through its relationship with the shopping centre: it caters to a specific kind of population that will continue to support its existence as a consumer-based model predicated on the economic support of an affluent public. While most shopping 
centres strive to create civic pride within their physical and aesthetic limits, often what is missing is a credible sense of community participation beyond the facility's primary use. The contrived spaces of the mall that recreate fantastical diversions of real or imagined environments does not allow for the possibility of spontaneous socialization that may occur in traditional public realms. Consequently, these types of artificial landscapes emphasize the economic aspect of the mall over the productive use of space.

The pedestrian areas of the mall are internalized, mimicking typical urban public streets with fake storefronts and promenades but dismissing any sort of perceived negative cord such as the presence of homeless persons or other controversial issues. While traditional urban areas are largely private, the civic realm that exists expresses itself in the form of conventional fronts to buildings, directional indicators, entry and egress. Interiorized civic space utilizes representational conventions of the inner and outer realms, and is likely to be radically different in type, scale and magnitude from its exterior counterpart. The exterior landscape and surrounding built-up environment invariably remain disconnected from the interior of the mall, and are reinforced by the mall's unassumingly blank façade.

The privatization of mall space detaches the socio-spatial relationships inside the mall from the outside world. Inevitably this results in an abandonment of public responsibility in the "public" space of the mall. ${ }^{9}$ Paradoxically, in contemporary shopping malls, the expressive responsibility is best exhibited on the inside where it is actually most private. Because of this, the public realm outside of the malls perpetuates a lack of identity in a sea of parking lots, roads and an abundance of signage. 
(sub)Urban Public Space: Shopping and Identity

Another aspect important in the construction of the (sub)Urban public sphere and shopping centres is defining identity through consumerism. The choices made in the act of consumption are described by John Clammer as a reflection of decisions about the self and about our social distinctions. ${ }^{10}$ Distinguishing a self-image is characteristic of the capitalist culture in which inner subjectivity is expressed through new social relationships and through the acquisition of material goods. ${ }^{11}$ The continual re-evaluation of personal standards and contextual situations affect the awareness of one's identity. ${ }^{12}$ The social recognition of difference such as class, subculture, and group membership are some of the factors that affect the way people generate an identity.

Identities can be theorized as a constantly updated narrative of self-identity focused on the individual. These narratives are incorporated into the self indirectly by means of social and political institutions and through the practices that constitute our social context. Identities are seen as multiple and unfixed. When applied to individuals, identities can represent normative and socialized categories. Shopping centres become a form by which the meaning of class is understood and generates individual identity formation. Identity therefore becomes related to a particular place or space both physically and metaphorically.

Shopping malls are a part of the process by which goods "communicate," and are "communicated" as, social relationships. In turn, we see malls as places that consistently reconstitute these relationships through various practices of shopping and other expressions of identity. ${ }^{13}$ Adolescent peer group experiences are also critical in the 
development of an identity. For teenagers the mall represents a micro-environment of empowerment since they are able to choose meaningful and self-identifying objects from a variety of products available within the mall. ${ }^{14}$

The identity and growth of a person is therefore mediated through the mall. The mall itself is a structure the public engages with in order to create an identity for itself and maintain or update it alongside product revisions. The act of shopping itself is a form of social exchange. Shopping has attempted to attract community events and to capitalize on the commercialization of seasonal occasions. The mall benefits from involving itself in community interaction because it attempts to gain an identity on the basis of locality. The typical strategy for malls to identify themselves in the community is through their name. Normally named after their location or place, the name encourages neighbourhood residents to identify with the mall and effectively support their local mall with the creation of a sense of place.

The following architectural examples attempt to challenge the existing spatial relationships and architectural identities that the mall has come to represent. Their attempts at redefining their relationship with its community and critically addressing specific problems that have impacted the mall's viability, generates a sense of place and the opportunity for diverse publics to identify with the space of the products which they are purchasing. 


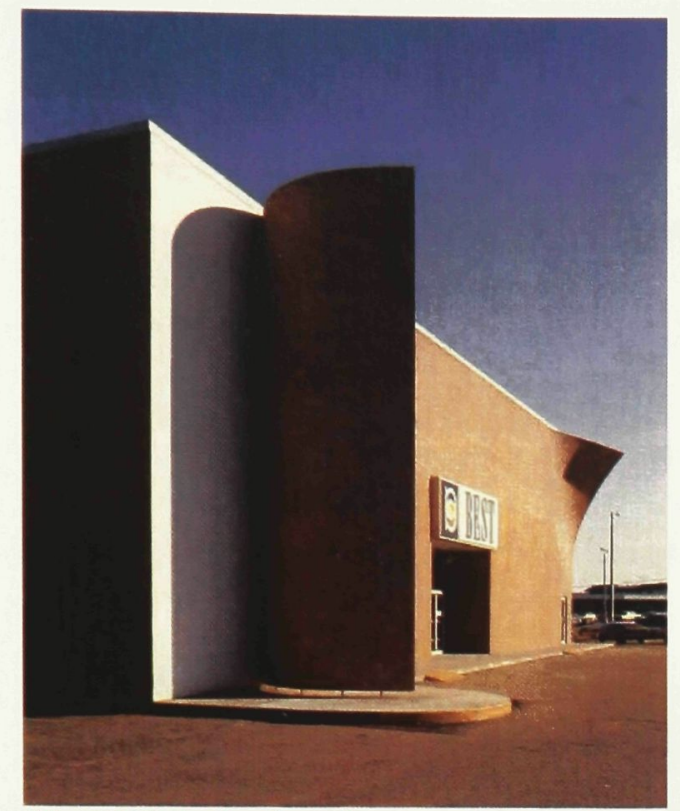

18: BEST's Peeling Project designed by SITE in 1972 from Nancy Goldring, "Highway Architecture." Ed.

Womersley, Steve. SITE Identity and Density. (Victoria: The Images

Publishing Group Pty Ltd. 2005) 42.
Best Productions Inc., a mail order

corporation, in 1972 hired SITE Architects to

develop a series of showrooms across America.

Located on the periphery of the city, the BEST

showroom prototypes were identifiable by their

generic appearance of rectangular brick boxes

surrounded by asphalt parking. SITE architects

unique designs for each of the nine commercial

buildings introduced the idea of individual concepts

that “... treats BEST's standard prototypes as the

subject matter or raw material for an art

statement."15 The first of these was the BEST Peeling Project in Richmond, Virginia.

Portions of the façade's brick veneer project into the space of the city, thus stressing the presence and importance of commercial structures on the periphery. The 'unveiling' of this façade reflected the impermanence of its morphological context. It attempted to engage the context of normality with visual ambiguity as well as change the public's view of the significance of commercial structures in the suburbs.

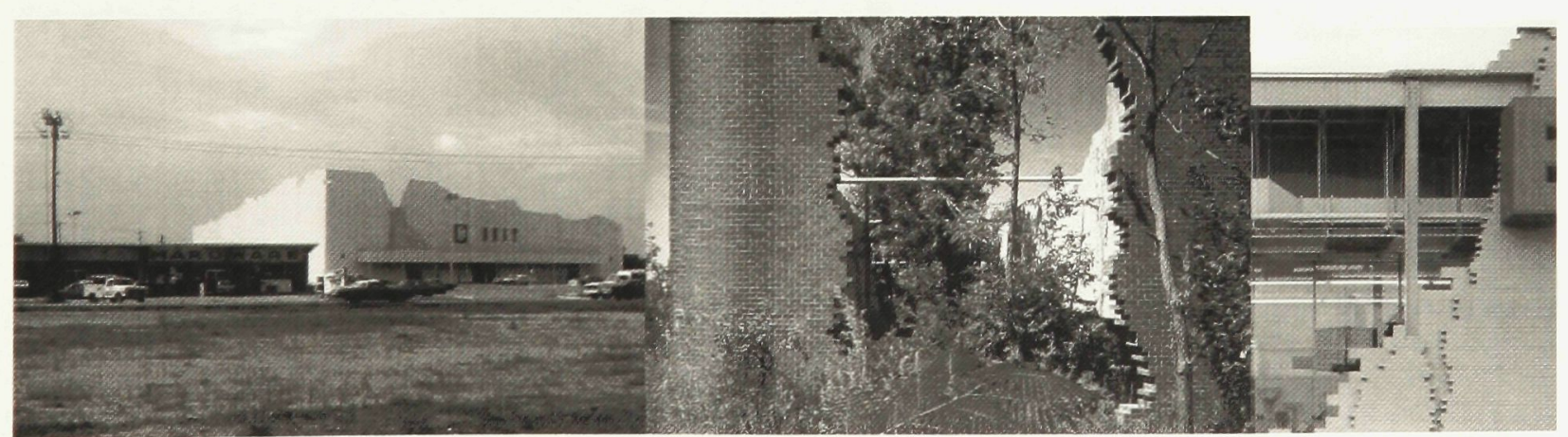

19: (from left to right) SITE's Indeterminate Facade Building, Forest Showroom, Inside/Outside Building built between 1975-1984, from Nancy Goldring, SITE Identity and Density. (Victoria: The Images Publishing Group Pty Ltd., 2005) 44, 58, 57. 
The other BEST buildings designed by SITE followed a similar artistic approach to their trademark designs. The dematerialization of its facade in the Indeterminate Façade Building, celebration of nature in the BEST Forest Showroom, and the externalization of interior architectural structures and commercial products in the BEST Inside/Outside Building demonstrated how SITE was able to influence the identity of these commercial buildings to suggest interplay between the actual and the surreal.

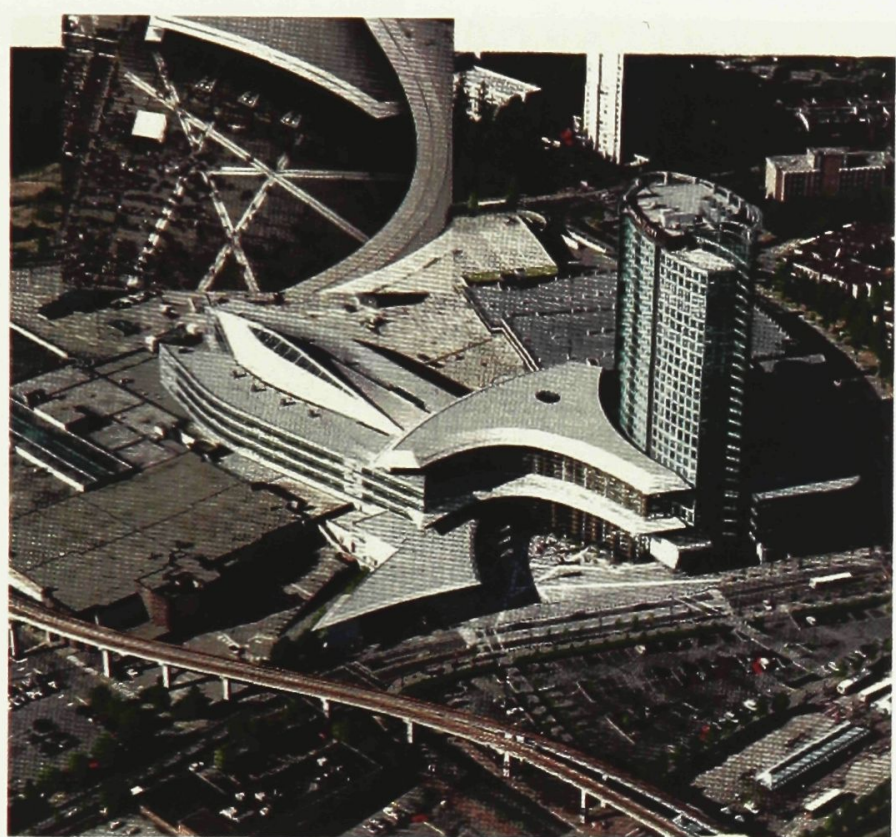

20: Surrey Central City, British Columbia by Bing Thom 2003 from Ellen Dunham-Jones,. "Suburban Retrofits, Demographics, and Sustainability" Places vol. 17.2 (summer 2005) 9.
More recent examples that demonstrate the imperatives to more socially conscious construction and contextual architecture can be seen in many new suburban mall retrofits. The idea of a retrofit implies a change that occurs in relation to its context, as it relies on the introduction of urban concepts such as street blocks and building typologies with the intention of

systematically reducing traffic, diversifying dwelling types, and preserving open space.

The majority of (sub)Urban retrofits are on 'dead mall' sites. ${ }^{16}$ The decline in many (sub)Urban mall sites is in part due to the increase in specialized big-box shopping centers. Known for their similarities to strip malls, these big-box stores are designed on a larger scale and are located beyond the periphery of (sub)Urban boundaries. In Surrey, British Columbia, the Surrey Central City designed by Bing Thom Architects 
incorporates a university, regional light-rail system, and a 25-storey office tower within an already existing mall. The dense grouping of new and existing buildings, and the rigorous use of apertures along the façade generates a sense of urban interaction in a (sub)Urban environment. The relationship between the public and private boundaries in the Surrey Central City becomes blurred and results in new social landscapes that serves as a background for prospective informal public gatherings and diversified social interactions that had been absent prior to the restoration project

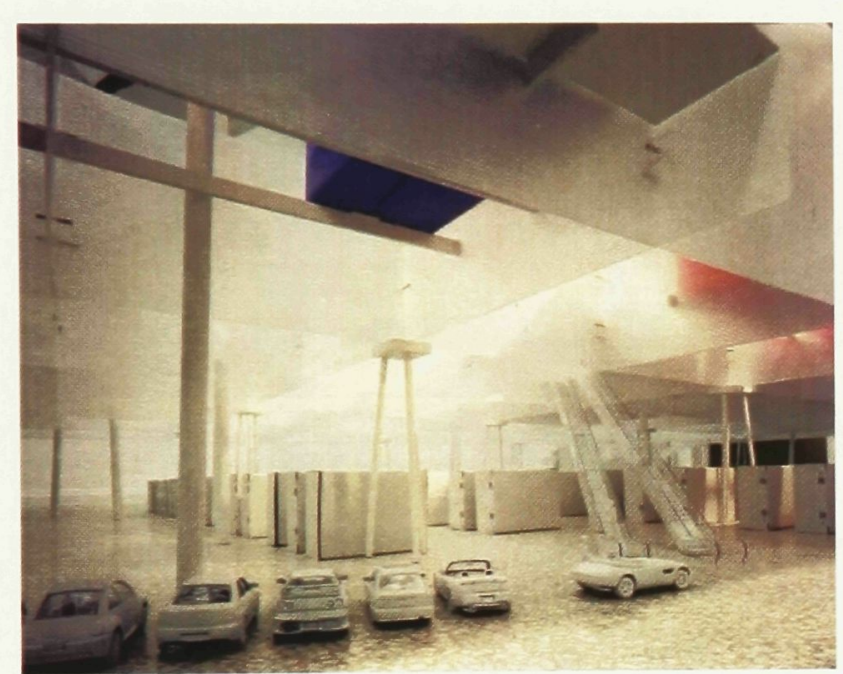

21: Shop Lift looking at small retail above from George Wagner, "Shop Lift". Canadian Architect vol. 50.9 (2005) 60 .

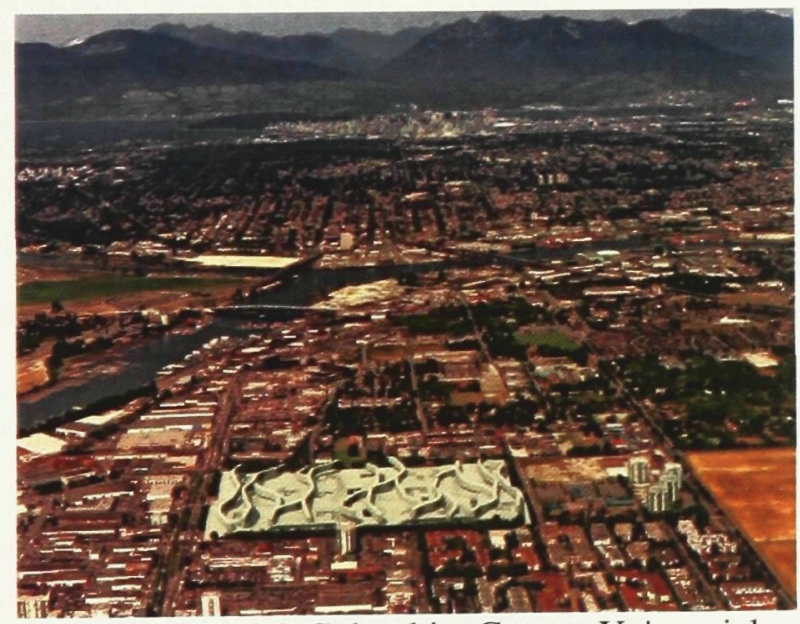

22: Surrey British Columbia, George Yu's aerial view of Shop Lift, 2004 from George Wagner, "Shop Lift". Canadian Architect vol. 50. 9 (2005) 60.
Another example involves an innovative proposal for a new mall in the suburb of Surrey, British Columbia.

Designed by George Yu Architects for the 2004 Venice Biennale; Yu’s project, named 'Shop Lift', is located on the site of the underused 50-acre Lansdowne Park Shopping Centre. Adjacent to the transit line linking Surrey to downtown Vancouver, British Columbia, the site is adjusted to the hours of business operation. Yu recognized the potential latent in the explosion of bigbox discount retail stores around the mall, which were taking business away from the mall's retail outlets. His concept was to extrude the entire "footprint" of the site into a 
vertical cityscape that included big-box retail and parking on the ground floor, small retail units on the first raised level, and a place for public landscape and residential 'noodles' on the top level.${ }^{17}$ For Yu the connecting points between the programs are the structural nuclei for this new type of urban reconstruction. These connection points are the instruments that guide the interaction between the public and private realms. Conceptually, the plan borrows from prefabricated construction techniques, recombined to form a structure to which hybrid landscape in the (sub)Urban space of the city can be added. The juxtaposition of the spaces in Yu's graphic representations suggests an ambiguity within the margins of the different levels of the building. The public park that resides above the mall references its mountainous landscape and attempts to infuse new meaning into the low-density, homogenous residential area with the introduction of an integrated typology. Taking cues from the fabric of Surrey's surrounding context, Yu was able to reinterpret the mall's everyday organizations by accommodating new developments such as 'big-box' stores and housing to create a new environment that increases population and building density as well as generating new layers of socialeconomic relationships and publics, that are typically concealed and homogenous, in the suburbs. 


\section{Chapter 4 Notes}

${ }^{1}$ Victor Gruen and Larry Smith, Shopping Towns USA: The Planning of Shopping Centers (New York: Reinhold, 1960) 11.

${ }^{2}$ Peter G. Rowe, Making a Middle Landscape (Cambridge: The MIT Press. 1991) 137.

${ }^{3}$ Ibid. 133.

${ }^{4}$ William Severnini Kowinski, The Malling of America: An inside look a the great consumer paradise (New York: William Morrow and Company, Inc. 1985) 118.

${ }^{5}$ Jeffrey M. Hardwick, Mall Maker: Victor Gruen, Architect of an American Dream (Philadelphia: University of Pennsylvania Press, 2004) 144.

${ }^{6}$ Ibid. 119.

${ }^{7}$ Ibid 119.

${ }^{8}$ Rowe op. cit. 130.

${ }^{9}$ Ibid. 49.

${ }^{10}$ Laura Langman, "Neon Cages: Shopping for Subjectivity". Lifestyle Shopping: The Subject of Consumption Ed. Rob Shields (Routledge: New York, 1992) 46.

${ }^{11}$ Ibid. 46.

${ }^{12}$ Ibid. 55 .

${ }^{13}$ Daniel Miller, Peter Jackson, Nigel Thrift, Beverley Holbrook and Michael Rowlands, Shopping, Place and Identity (New York: Routledge. 1998) 26-7.

14 Ibid. 48.

${ }^{15}$ Nancy Goldring, "Highway Architecture." Ed. Womersley, Steve. SITE Identity and Density. (Victoria: The Images Publishing Group Pty Ltd. 2005) 42.

${ }^{16}$ Ellen Dunham-Jones, "Suburban Retrofits, Demographics, and Sustainability" Places vol. 17.2 (summer 2005) 9.

${ }^{17}$ George Wagner, "Shop Lift”. Canadian Architect vol. 50.9 (2005) 60. 


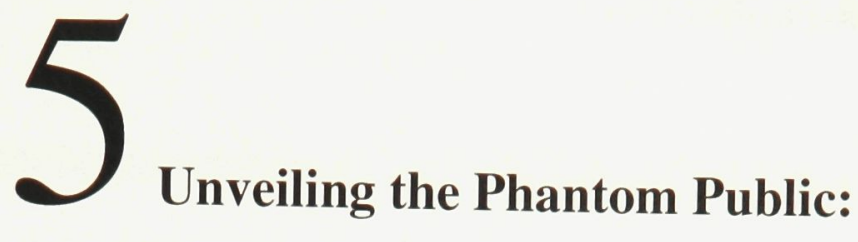

Developing a Mixed-Use Typology for the (sub)Urbs
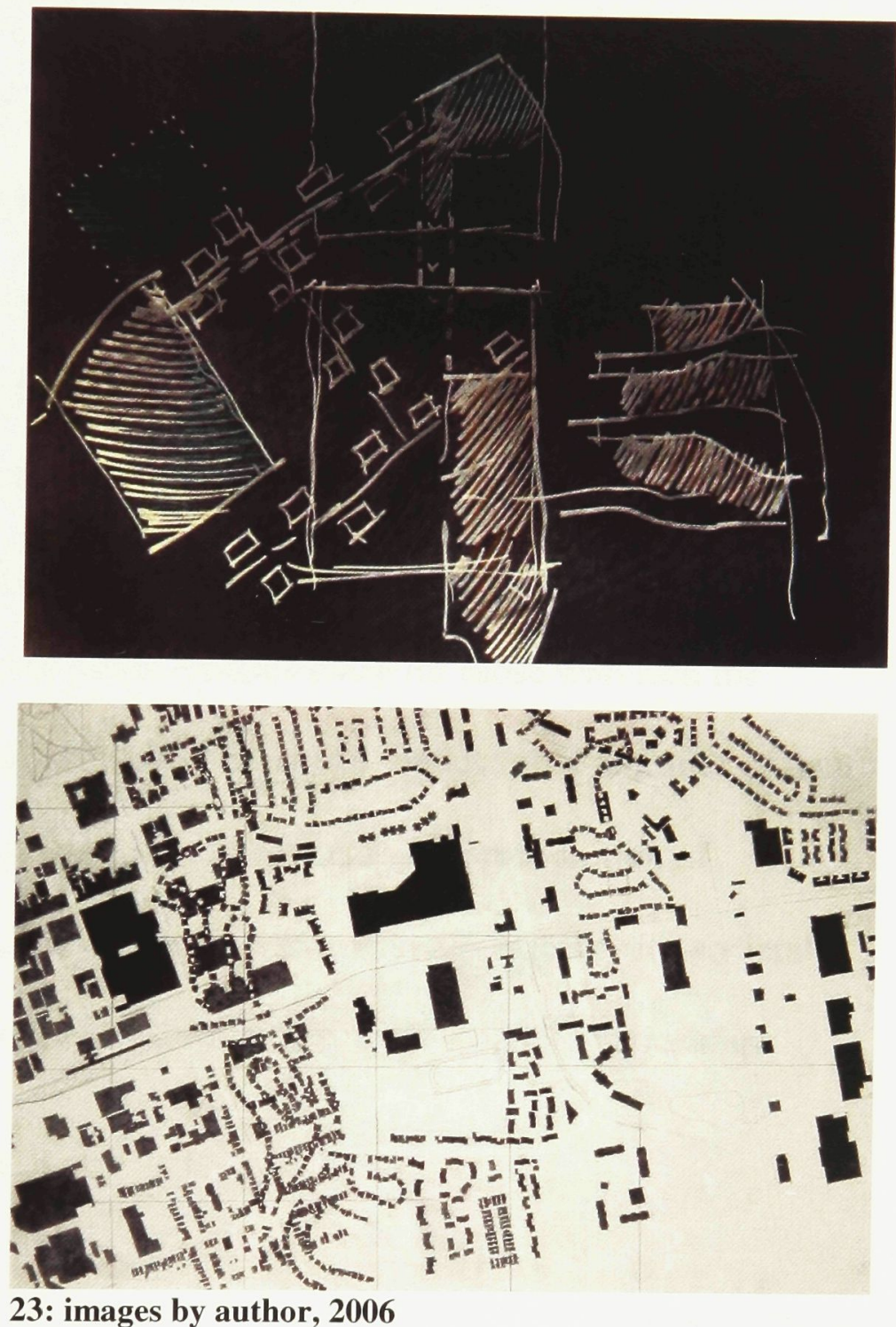

23: images by author, 2006 
Process

Introduction

The polarization of public space following modernization has brought about the notion of a homogenous and transparent public. But the impact of urban decentralization and the growth of suburban metropolises occurring at the edges of the city have once again generated a shift to the idea of a public realm as well as to the need for determining what constitutes a public body. For designers and planners, attempts to integrate other forms of public space, such as the suburban mall, have challenged the conventional notion of public space disguised as a pseudo-sphere.

Through the analysis of the spatial organization of the suburban mall, the decision to remove all social or spatial contradictions is evident. The transformation of public open space into privatized indoor space restricts the uses that are possible within these semi-public locations. These privatized spaces exclude entry for those who lack the necessary cultural or economic capital and who are marked 'undesirable' because of their appearance or simply because they are considered 'loiterers'. The recognition of conflicting spatial relationships and representations removes the possibility for societal differences to exist as part of a wider interpretation of the social-spatial relationships within the context of the mall.

\section{$\underline{\text { Investigation }}$}

In this thesis, the first set of investigations deals with small scale designs that are inspired by the works of Martha Rosler. The second investigation in the making of a 
Phantom public sphere is a series of multi-use buildings, located on the property of The Westmount Shopping Centre in London, Ontario.

The concept will guide the production of an architecture that provides a surface to the possibilities that are inherent in the Phantom public. Since shopping centres are considered to be civic centres for their surrounding residents, a renewed vision of its physical, social and psychological organizational relationships of the suburban territory will encourage a unique participation of an active and more diverse public realm. An architecture that re-establishes the relationships between the public and the private realms in the existing pseudo-public realm of the mall, has the capacity to create multiple alternative public spaces. These spaces can challenge existing social and political assumptions in the fabric of the suburban metropolis expressed as impromptu performance and civic events that are juxtaposed against the space of a consumer culture. 


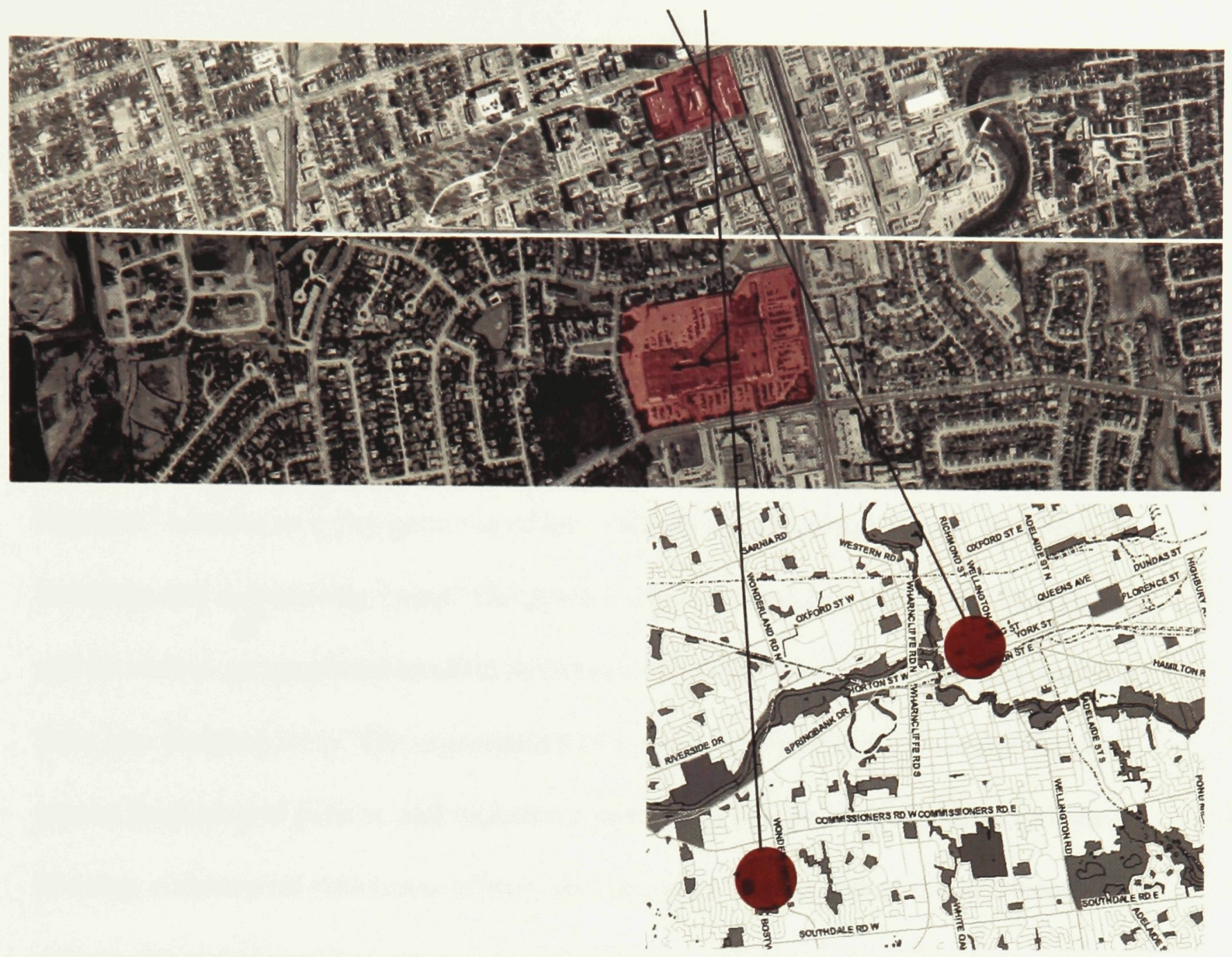

24: Aerial photo showing the site of Westmount Mall in relation to London's downtown core.

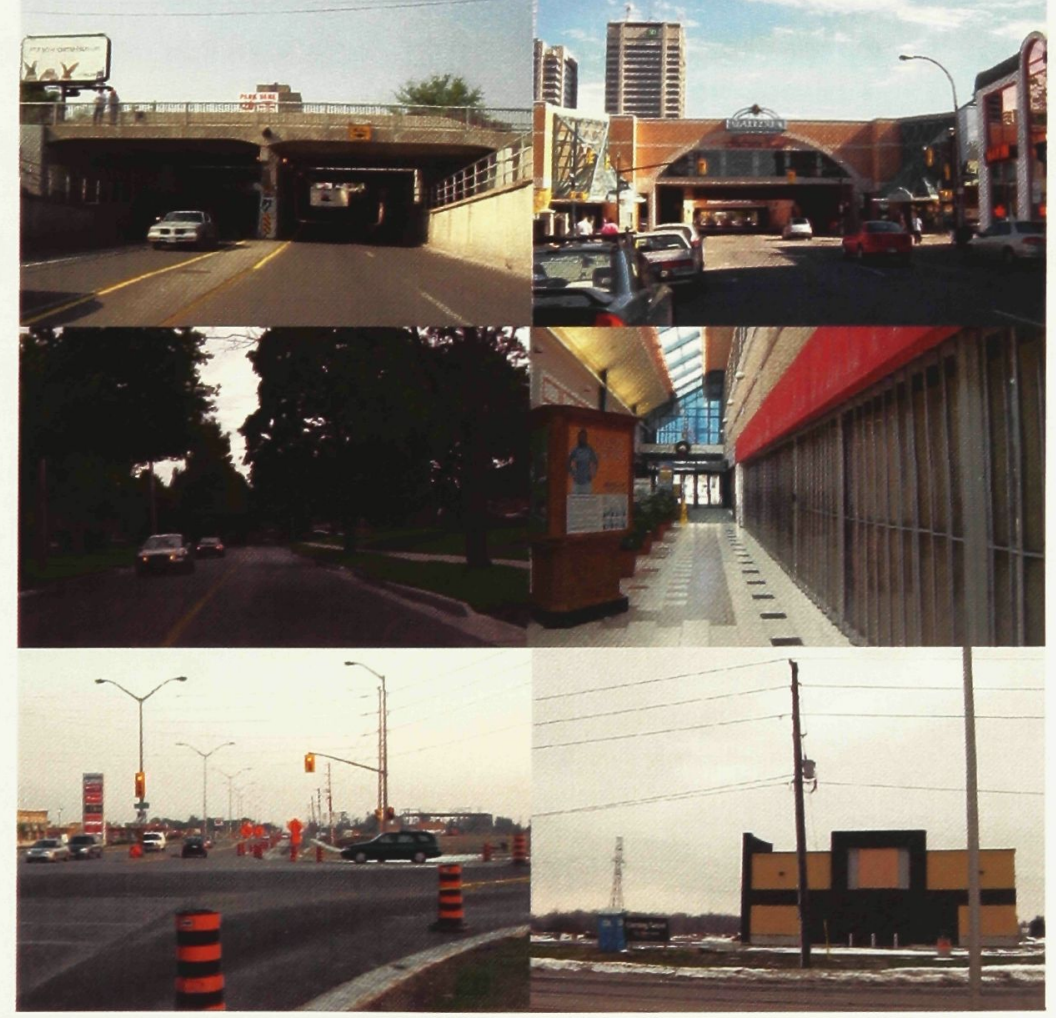

25: Mall to mall to mall, (top) downtown, (middle) Westmount, (bottom) south London periphery. Photographs by author, 2006. 
Site: London and the Westmount Shopping Centre

Located at the fork of the Thames River, the City of London, Ontario was officially founded in 1826 by Lieutenant Governor John Graves Simcoe. Its potential for becoming the future capital of the province disappeared when Toronto assumed this function. ${ }^{1}$ London as a city grew out of the centrally located Court House, government buildings and surrounding farms. The development of London's commercial dominance and its central geographical location in Ontario led to the construction of transportation lines into outlying areas. The organization of London's downtown grew according to a typical English grid pattern, and included a mixture of government buildings, private housing, commercial structures, offices, and churches. By the end of the nineteenth century the population had increased by 42 percent, and the residential section expanded into the eastern, western and southern parts of the city in the form of supplementary residential suburbs. ${ }^{2}$ These suburbs eventually became the symbol of the city's growth which continued in this manner, resulting in numerous decentralized nodes of selfsufficient neighbourhoods. 
The Westmount Shopping Center, built in 1973, remains the main commercial focus of the community, providing food, clothing and entertainment. Redeveloped in the late 1980's by architects Crang \& Boake Inc., the Shopping Center's new identity was a post-modern double-height building with minimal apertures or unique identifying characteristics. At approximately 600, 000 square feet, the two-storey mid-sized mall is surrounded by 2300 above-ground parking spaces and a further 950 spaces underground. The layout of the mall uses a traditional 'dumbbell' plan that includes two department stores as anchors, as well as a six-screen movie theatre. ${ }^{3}$ Built within an equally vast parking lot, the mall remains a self-contained island among thousands of square feet of asphalt. The façade of the mall does not denote more than a blank brown and beige canvas of brick punctuated with entrances that are grossly articulated by glass-block and canopy.

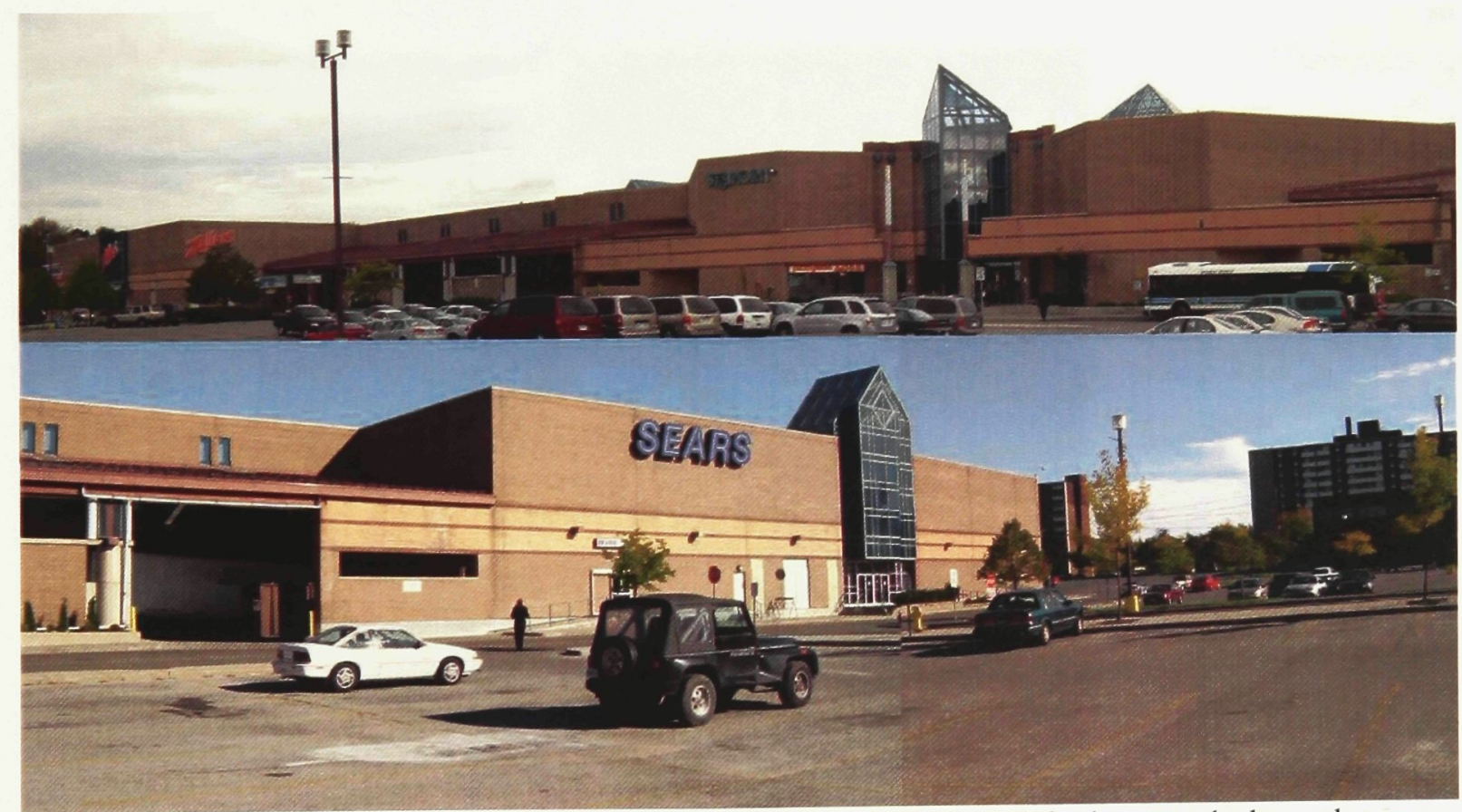

26: Westmount Shopping Centre, South Facade facing Viscount Rd., 2006, photographs by author. 


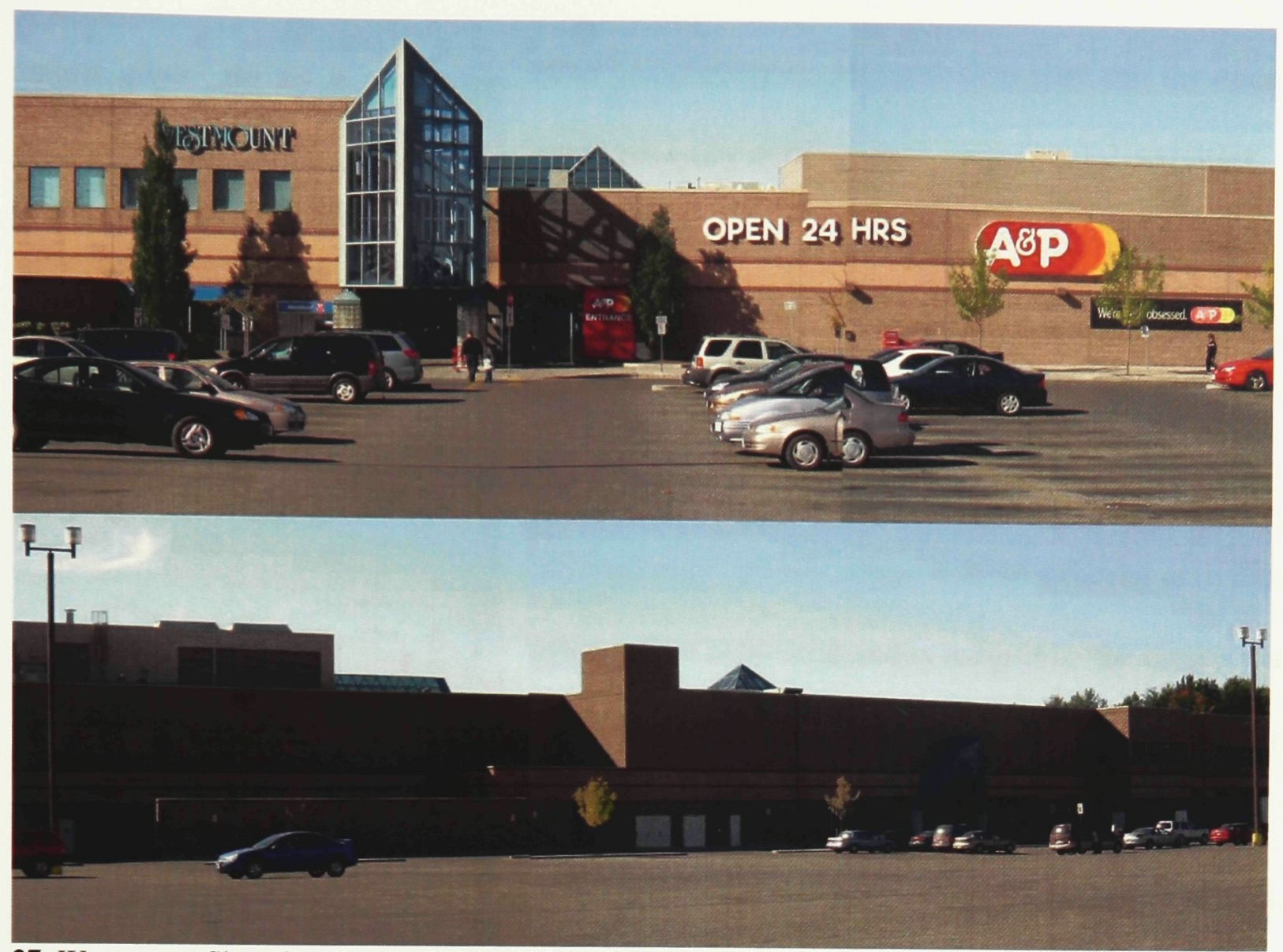

27: Westmount Shopping Centre, 2006 (top) East Facade, (bottom) North Façade, photographs by author.

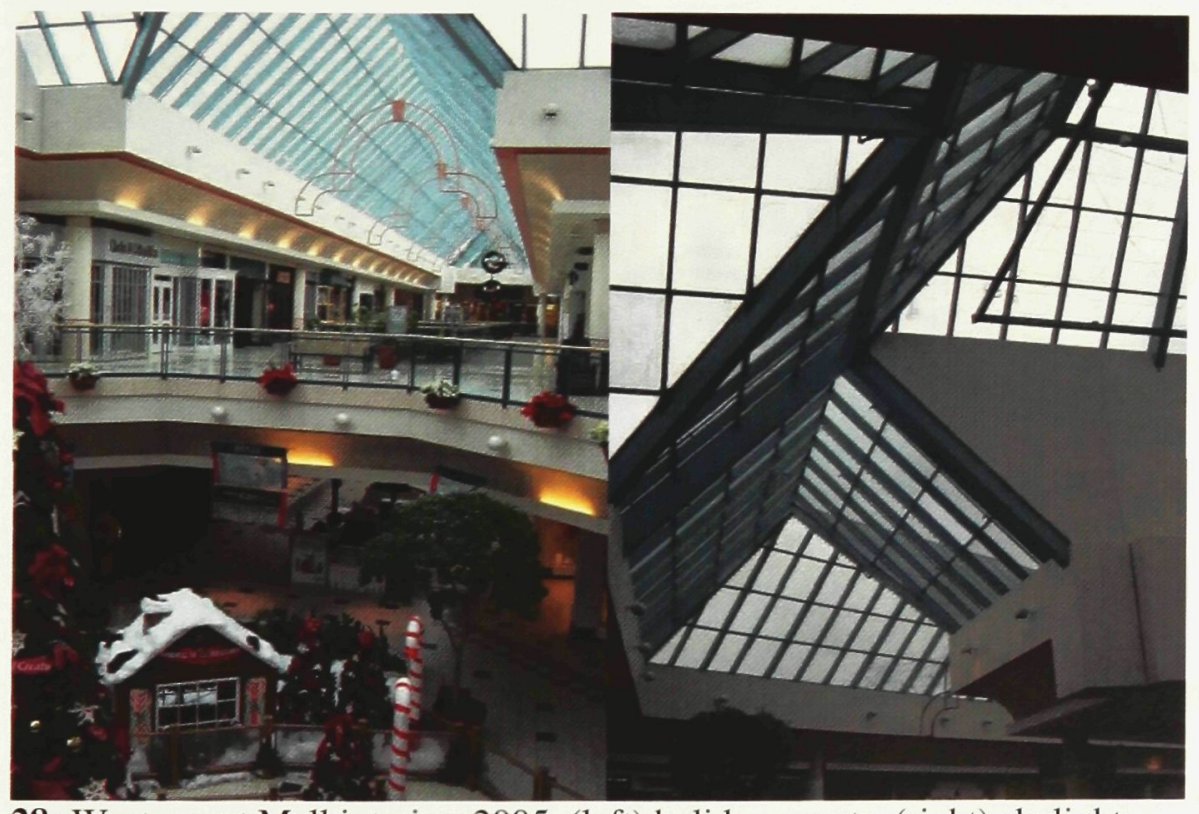

28: Westmount Mall interior, 2005, (left) holiday events, (right) skylights allow maximum natural lighting, photographed by author.
Currently the

vacancy rate is less

than ideal, standing at

9.8\%. Due to this drop in retail

establishments, it was necessary to introduce other types of

programs, such as

driver education and 

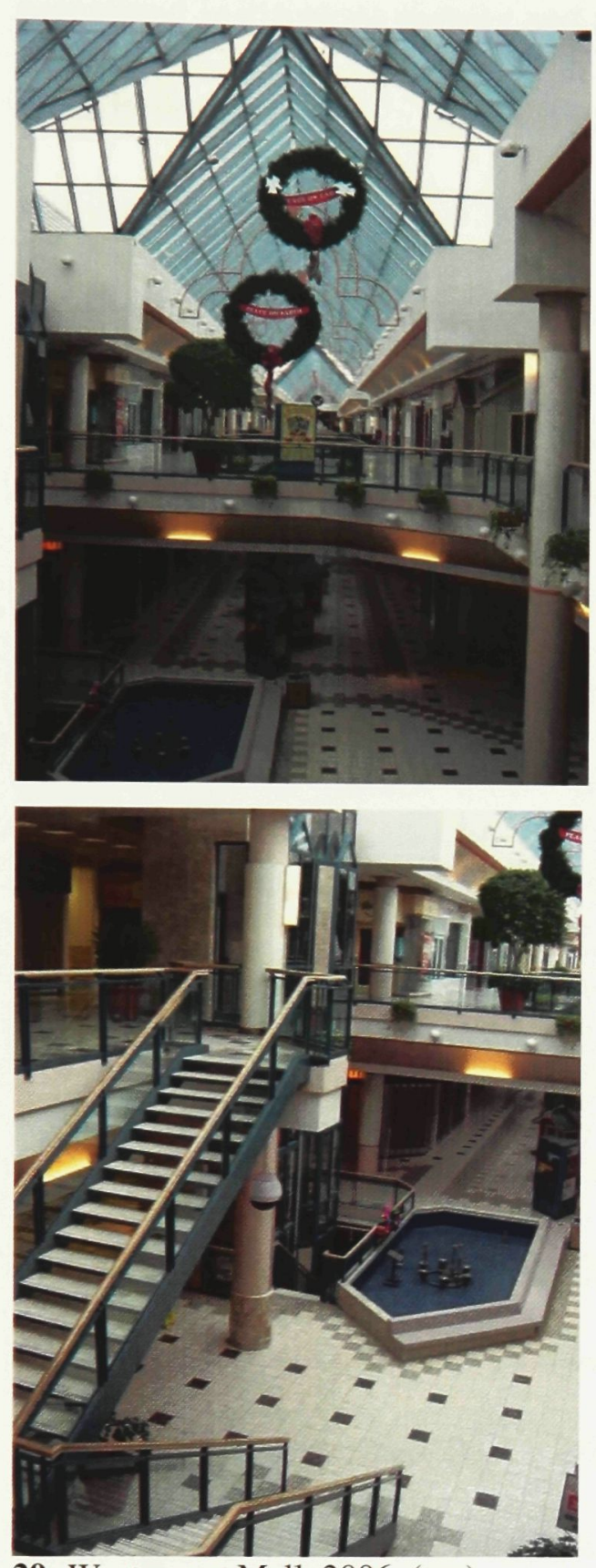

29: Westmount Mall, 2006, (top) showing main interior corridor, (bottom) showing circulation, photographed by author. and eat.

other community related activities that rent the once predominantly retail spaces. Other social activities that regularly take place are mall-walking, tai-chi, dance performances and school-related events. This utilization of the mall suggests a need for a public forum to accommodate these types of events. While the mall may already support these existing activities, this support is limited and is subject to the discretion of the shopping centre's convenience, as determined by its management.

The demographic mix of the Westmount area is slightly older than the rest of the London, a large percentage of it consists of middle-aged residents, both married and single. ${ }^{4}$ Even though mornings and weekends are dominated by elderly citizens using the food court for socializing, during the week in the early and late afternoons the mall is saturated with high school students looking for a place to meet, shop

The shopping center is surrounded by a variety of housing and institutional buildings. The mixture of these varied programs suggests the possibility of developing dynamic relationships among the various groups, with the locus of the array being the shopping mall. Unfortunately, its low density planning scheme and its distinctly 
privatized institutions restrict and control the mobilization of impromptu activities that were to develop. On the east side of the mall is Wonderland Road. A major four-lane north-south roadway, it supports many bus routes and provides easy access to other locations for the neighbourhood residents. Its connection to the northern and southern extents of the city provides networking for university students in the north and access to major and minor highways in the south. Secondary roads such as Viscount Road on the south side of the mall and Village Green Avenue on the north side are important connective streets for the local community while the west side is bounded by Woodcrest Blvd., a small residential street. Single-family housing dominates the area. In addition there is a scattering of institutional and office buildings around the site. To the south one finds Saunders Secondary School, Westmount Public School, Jean Vanier Separate School and a gas station at the intersection of Wonderland and Viscount Roads. On the south-east corner of the shopping mall parking lot stands an office building, a local pub, and some office space. High-rise apartment buildings from the 1970's line the east side of Wonderland Road which terminates at the Baptist Church on the corner of Village Green Avenue and Wonderland Road. Across the street is the Westmount Presbyterian Church, while along the north and west sides of the shopping mall we find a mixture of townhouses and single-family homes. 
Walking Route Maps
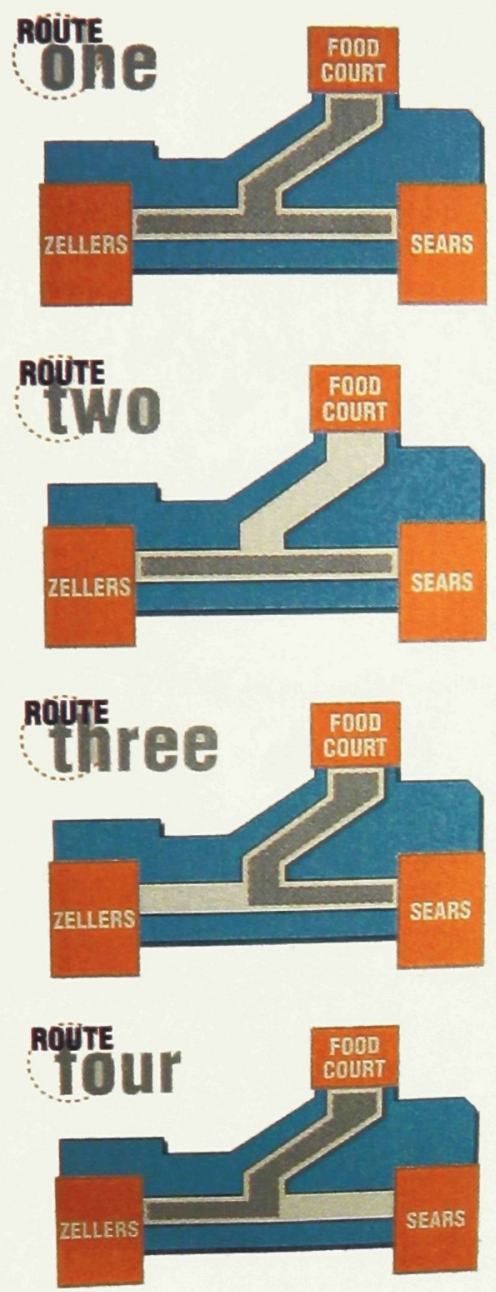

30: Walking map for the Westmount Shopping Centre showing four routes, from a Westmount Shopping Centre brochure.
The assortment of building types in the immediate area of the shopping centre would seem to suggest that the utilization of space would be active and vibrant. But due to the scarcity of programs and the temporary occupation of private and institutional buildings, during day-time hours the possible activities that occur in the civic space is limited and adjusted to the mall's hours of operation. 


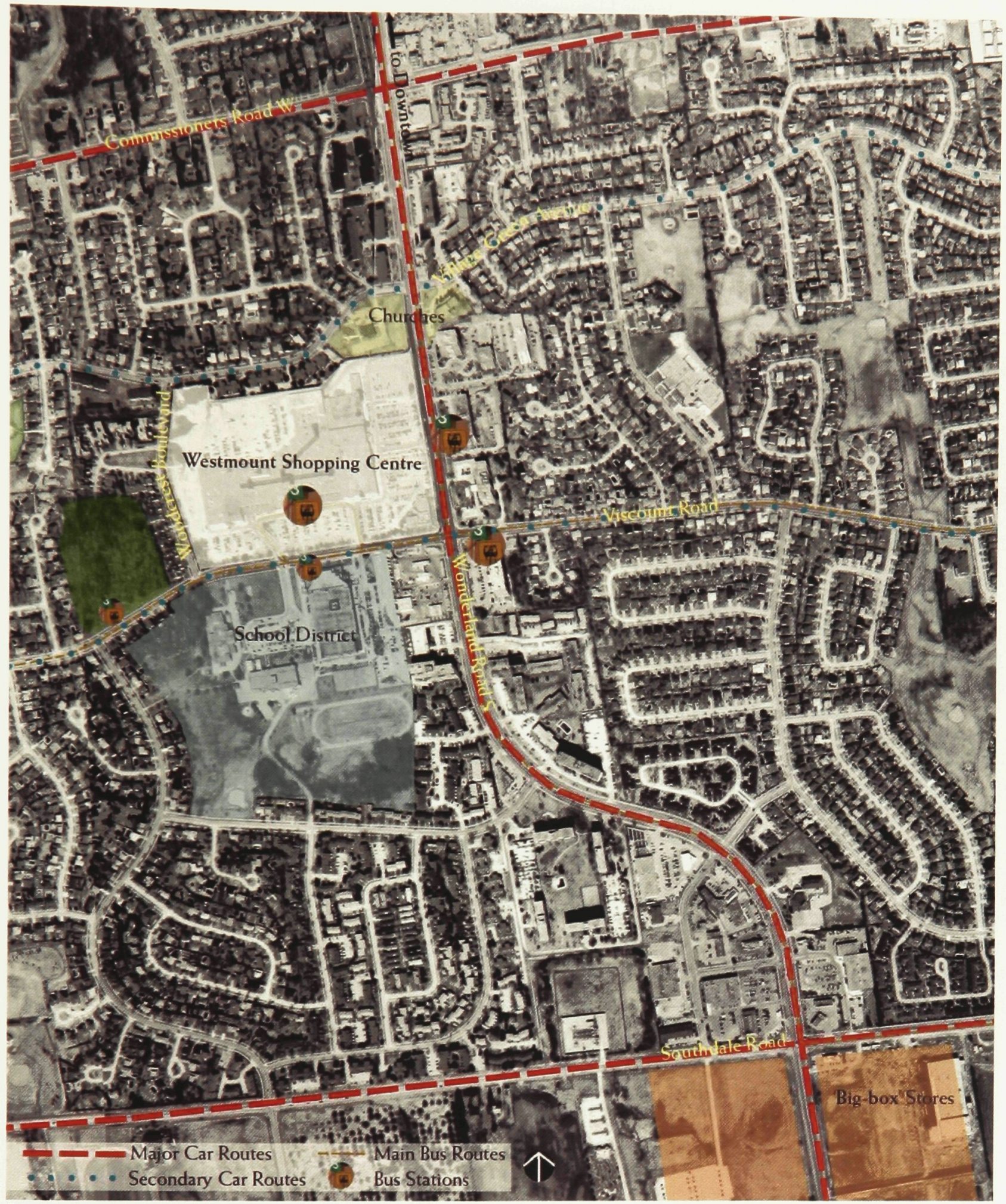

31: Major Automobile and Public Transportation Routes 


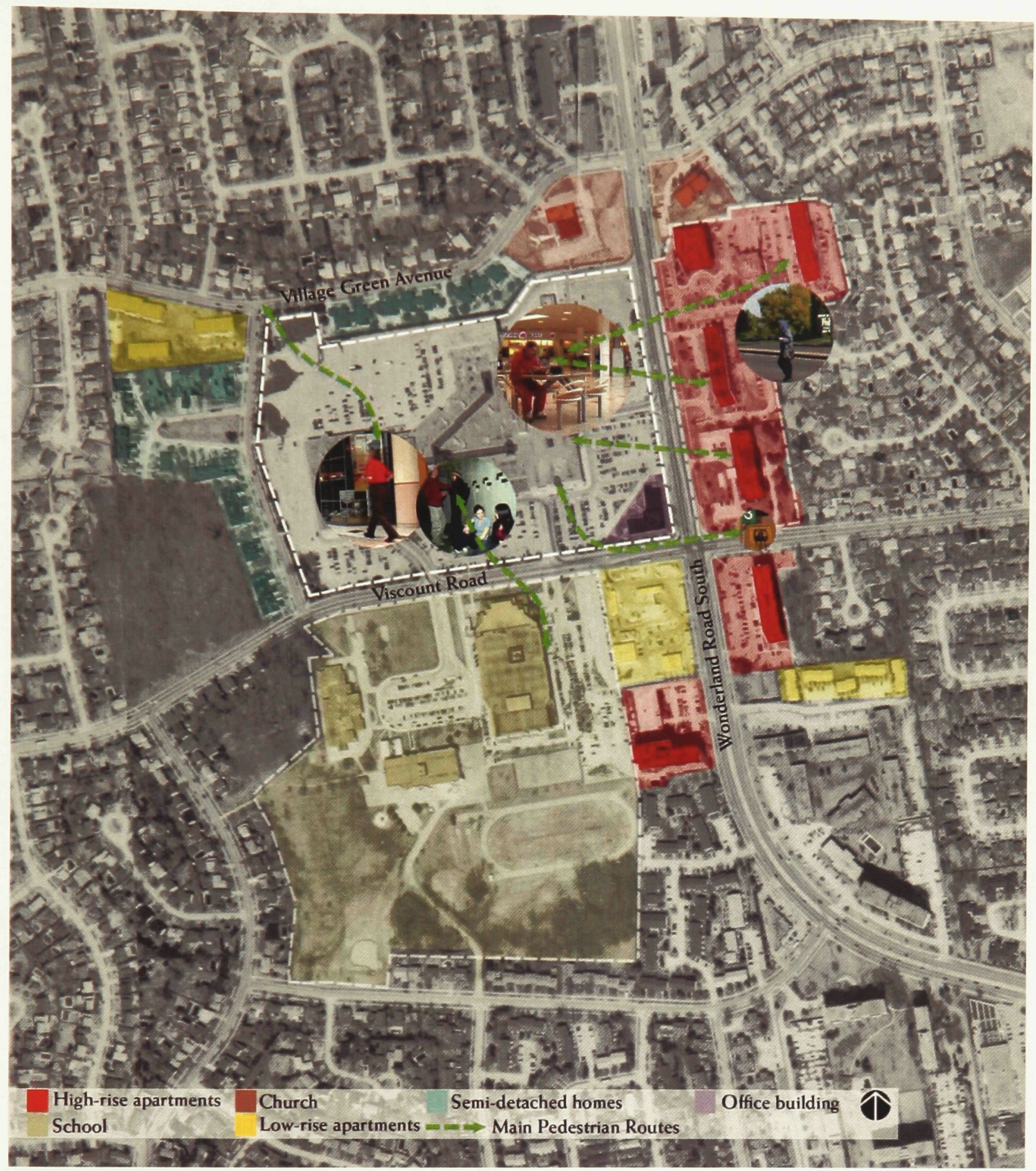

32: Building Types and Main Pedestrian Routes 


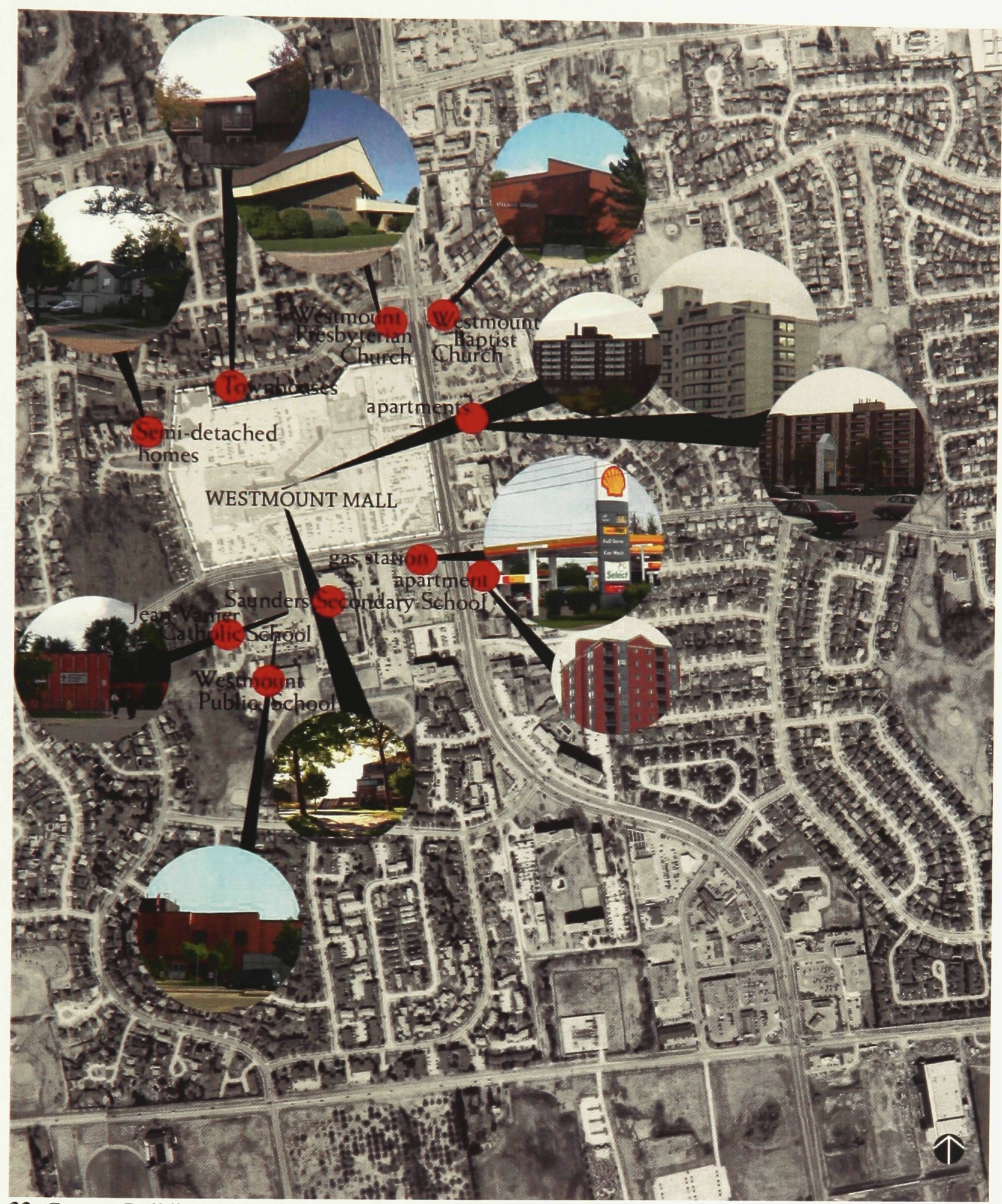

33: Context Buildings around Westmount Mall 


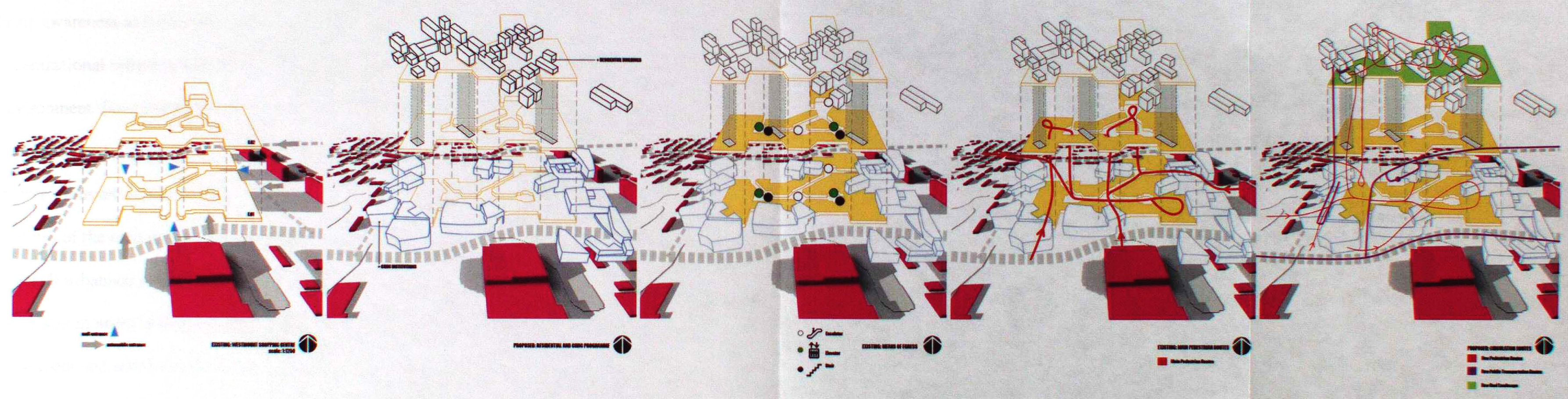

34: Diagrams (left to right): existing mall, residential \& civic programmes, existing means of egress, existing main pedestrian routes, proposed circulation routes. 


\section{Investigating the City: Production of a Contested Landscape}

The first series of investigations into the suburban realm seeks to examine the potential transformation of public space into a socially meaningful environment. Inspired by Martha Rosler's urban exhibition “If you lived here...", these interventions attempt to bring awareness to issues that plague the (sub)Urban realm by subverting its organizational infrastructure through the creation of new relationships between user and environment. Four interactive small-scale interventions were produced to exhibit the conflicting and uneven processes that occur in the area of the shopping mall. The interventions attempt to produce an alternative space, which will reveal the normalized routines of the mall and encourage the consumers to critically observe their surrounding space. If urbanism is perceived as a condition or event, one that occupies time and place in a given moment, an intervention within the mall site can begin to incorporate existing movement and stability in order to create new relationships between different groups of people. The existing infrastructure assumes movement as a crucial component in the experience of the consumption of products, but the interventions reveal new relationships that are gained through the juxtaposition or layering of new spaces with existing spaces. 


\section{"Big-Box" Intervention}

The first intervention responds to the proliferation of "big-box" stores on the periphery of the (sub)Urban municipality. The expansion of these stores has detracted consumers from the mall and, as a result, diverts any sense of community that may have existed to a space that is thoroughly designated for consumption. The introduction of habitable spaces that are extruded from individual parking spaces creates a matrix of potential places for interaction, or for small retail opportunities that are supported above or on the surface of the parking spots (Fig. 35b). The matrix of modules potentially places retail outside the boundary of the mall space amongst the vehicles in the parking lot. The intermixing of the two functions proposes to engage the user and his intended destination in a microcosm of big-box stores in the vicinity of the parking lot. Through consumer navigation between these new spaces, spontaneous interaction and the formation of new relationships would potentially occur.

\section{Parking Void}

Corresponding to the Big-Box intervention, the parking lots in an urban setting provide a large amount of parking within a relatively small "footprint." However, the effect of these cavernous multi-level structures can be quite deleterious. After the closing of the mall, the parking area is left as a void in the landscape of the urban fabric. The 
"accommodation" of the homeless is at best the only function the structure serves at night.

This second intervention involves the incision and removal of parking spaces in the floor of the parking lot (Fig. 35a). The vertical voids that are created allow light into the lower levels of the parking, and visually connect the layers of the structure. The extraction from the parking garage represents the removal of "undesirable" occupants and the dominance of controlled space. At the same time, automobiles are forced to navigate around the voids that interrupt the user's preconceived notions of everyday space.

\section{$\underline{\text { Road Signs }}$}

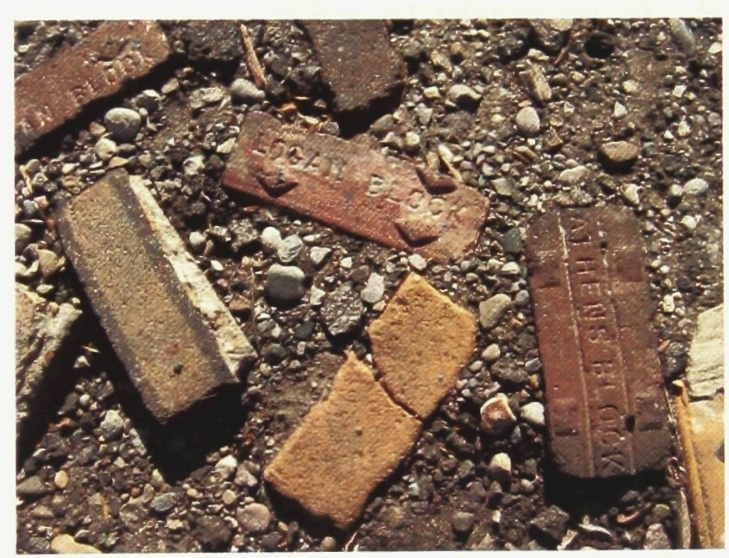

The third investigation was inspired by found objects in the downtown area of London, Ontario. Discovered on the shoulder of a small side road, the inscribed bricks appeared to have been left-over remnants that were integrated into the ground along the street. The exposed layers of material suggest a narrative unique to the specific area that may or may go unnoticed by its citizens.

The intervention in the suburbs involved the embossing of the asphalt streets adjacent to the mall site (Fig. 35d). Designed to graphically spell out the names of the streets, the 
voids are spread out to accommodate the speed of a vehicle. Pedestrians cannot discern a unified image of the text, they can only see the separate components of the whole.

Furthermore the indentations indicate to drivers that they are approaching a specific area of the city once they cross the threshold. The codified street becomes a way to interact with pedestrians but especially with the automobile users. The importance of engaging autoists relates to the idea of private space. Since the car acts merely as an extension of the private realm of the home into the city, by translating cues from the road to the motorist they inexplicably become implicated with their surrounding environment. More subtle than confrontational, the crossing of the threshold creates a memory associated with the place that is differentiated from the other areas of the suburbs.

\section{The Mediating Wall}

The final intervention is a wall that assumes the space between the parking lot and the mall's exterior wall. Built parallel to the sidewalk that services the mall, the wall uses wood blocks and is arranged into a perforated assembly (Fig. 35c). Placement of the free-standing wall assemblies occur at points of entry by both pedestrians and cars. For onlookers, the wall begins to frame the pedestrians through an open façade that appears pixelated. While many of the vehicular entry locations terminate in a blank façade, the proposed wall interventions shift the hierarchy of the mall to place greater emphasis on the importance of the users and their relation to the exterior environment. Because of its placement at the points of entry, cut-outs made in the wall frame the shoppers that inhabit the space in-between the newly introduced wall and the existing wall. 
The placement of a free-standing wall outside of the mall contests the impermeability of the mall's facade, and produces an intermediary condition between the space of the street and the mall. The transformability of the wall allows the users to manipulate the wall to form open areas that would allow for outdoor seating. Moreover, the wall reveals a fragmented image of its suburban context in a pixilated mosaic, which is located on a single face of the wall 'blocks'. The movement of the wall constructs and deconstructs the image in various configurations physically changing the façade of the building but also acting as a metaphor of a continuously shifting suburban 'image'.

\section{$\underline{\text { Surveys }}$}

As another investigation into the phenomena of the suburban shopping centre, surveys were conducted in the St. Laurent Shopping Centre in Ottawa, Ontario (Appendix A). The survey addresses specific routines of the consumers and investigates their relationship to the perceived public space of the mall. ${ }^{5}$ From the 38 randomly selected participants, their responses to the survey inspired the making of a conceptual model. The experience of the operations which engaged the participants to answer the survey questions were represented in a 'machine for viewing'. This conceptual model graphically shows the responses acquired. It also functions as a viewing device to interact with a viewer to disseminate information that is interpretable and open to discussion.

The social structures that informed the system of public opinion were studied in terms of the relationships between user and mall, mall space and space of the city, and identity of the mall within the context of the suburban environment. Many of the 
respondents agreed that the presence of a public space in or around the mall would be positive for the neighbourhood meanwhile; they considered the mall itself a public place. Most of the respondents also agreed that the mall itself either does create or has the potential to create an identity with the neighbourhood and can become a landmark for the residents to identify with and project a certain image for the predominantly residential area.

The proposed building on the site of the Westmount Shopping Centre is intended to negate the uneven, and linear rhythm that permeates the site, with the presence of new multi-functional private and public spaces. The interventions and conceptualizations of ideas investigated in the initial stages of the proposal will help to form typological and phenomenological responses through the absence or presence of architectural interventions. 

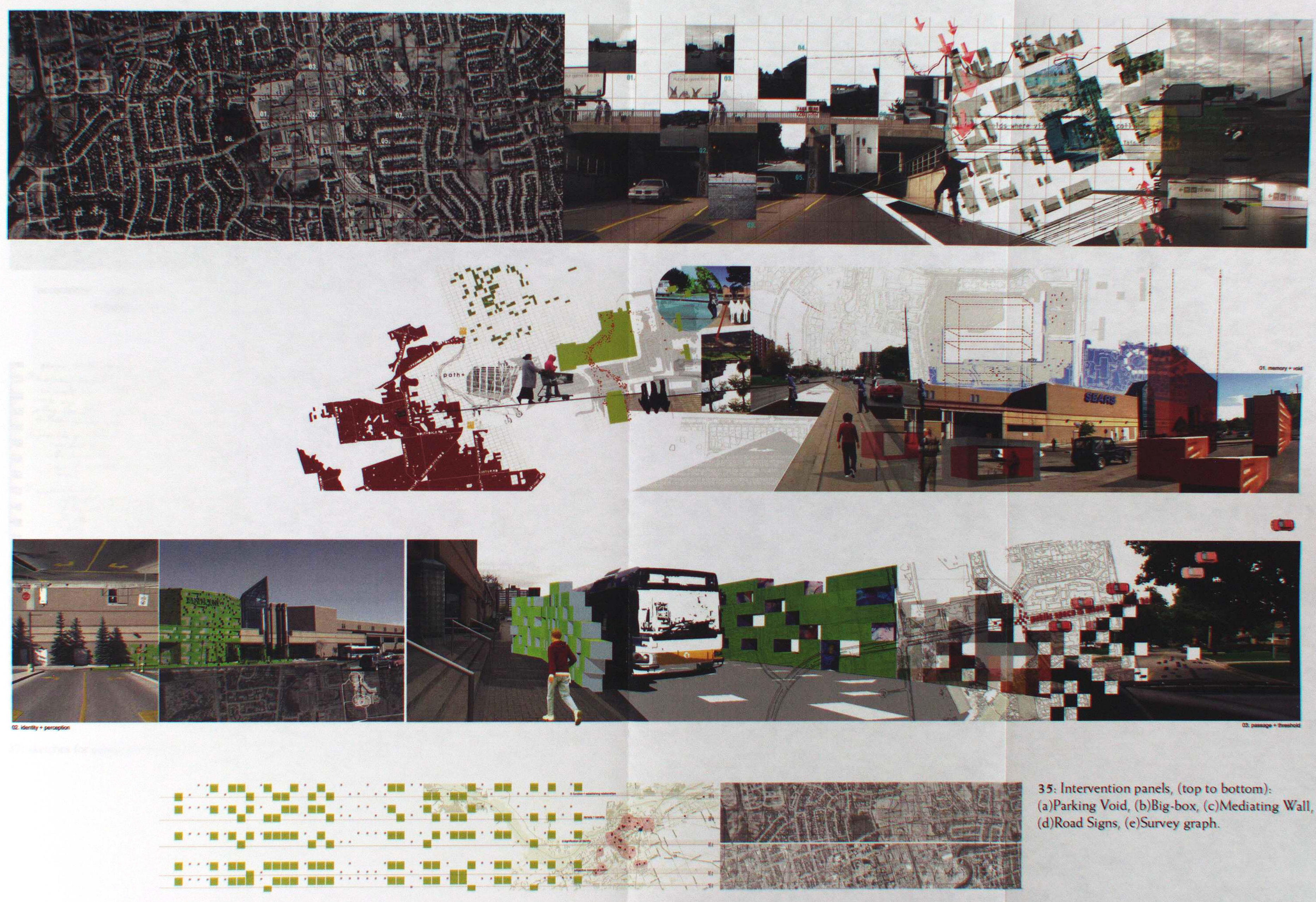

35: Intervention panels, (top to bottom): (a)Parking Void, (b)Big-box, (c)Mediating Wall (d)Road Signs, (e)Survey graph.

둘

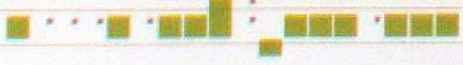

man 

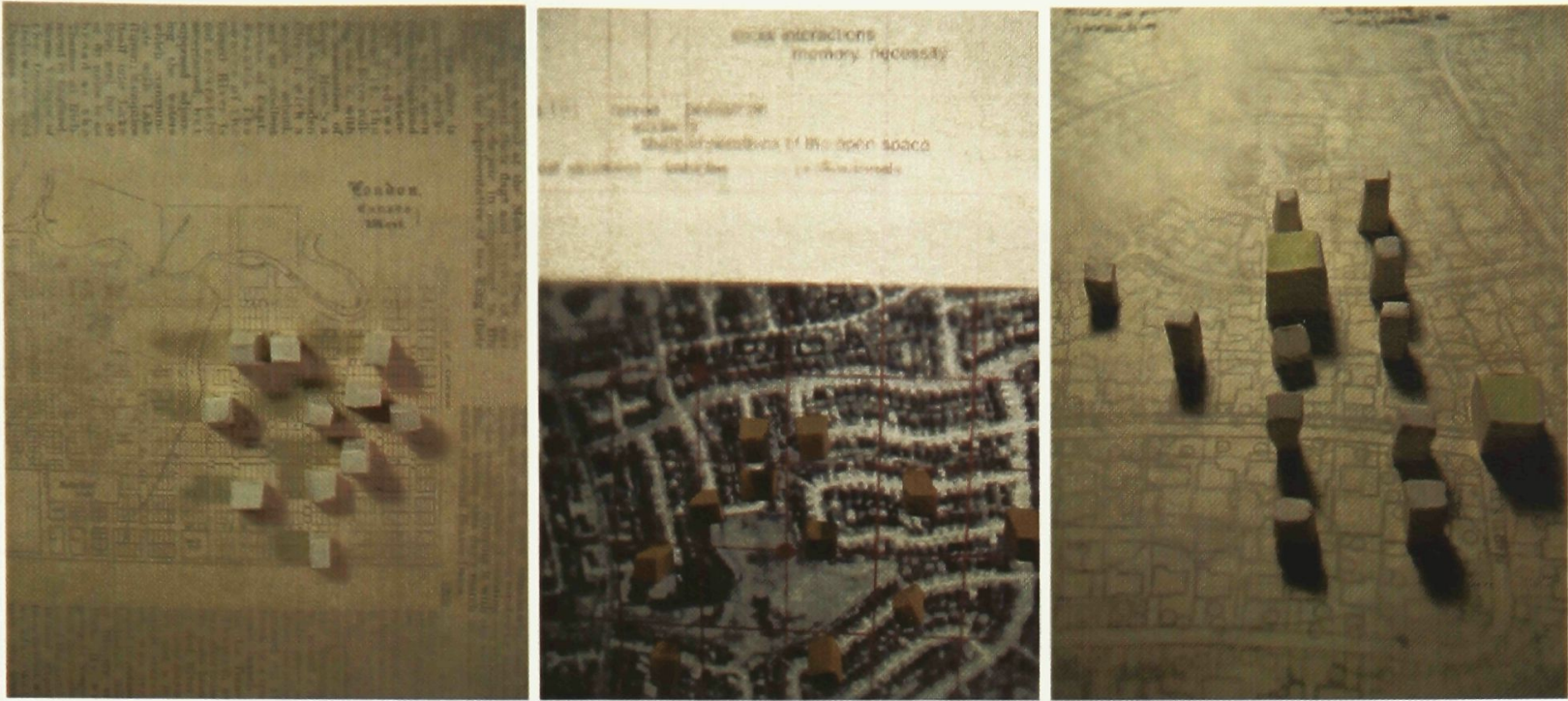

'eccentricity' : Creation of discord in the organization of the city due to the modification of a system

Adaptation of a modification results in renewed development surrounding the existing structures.
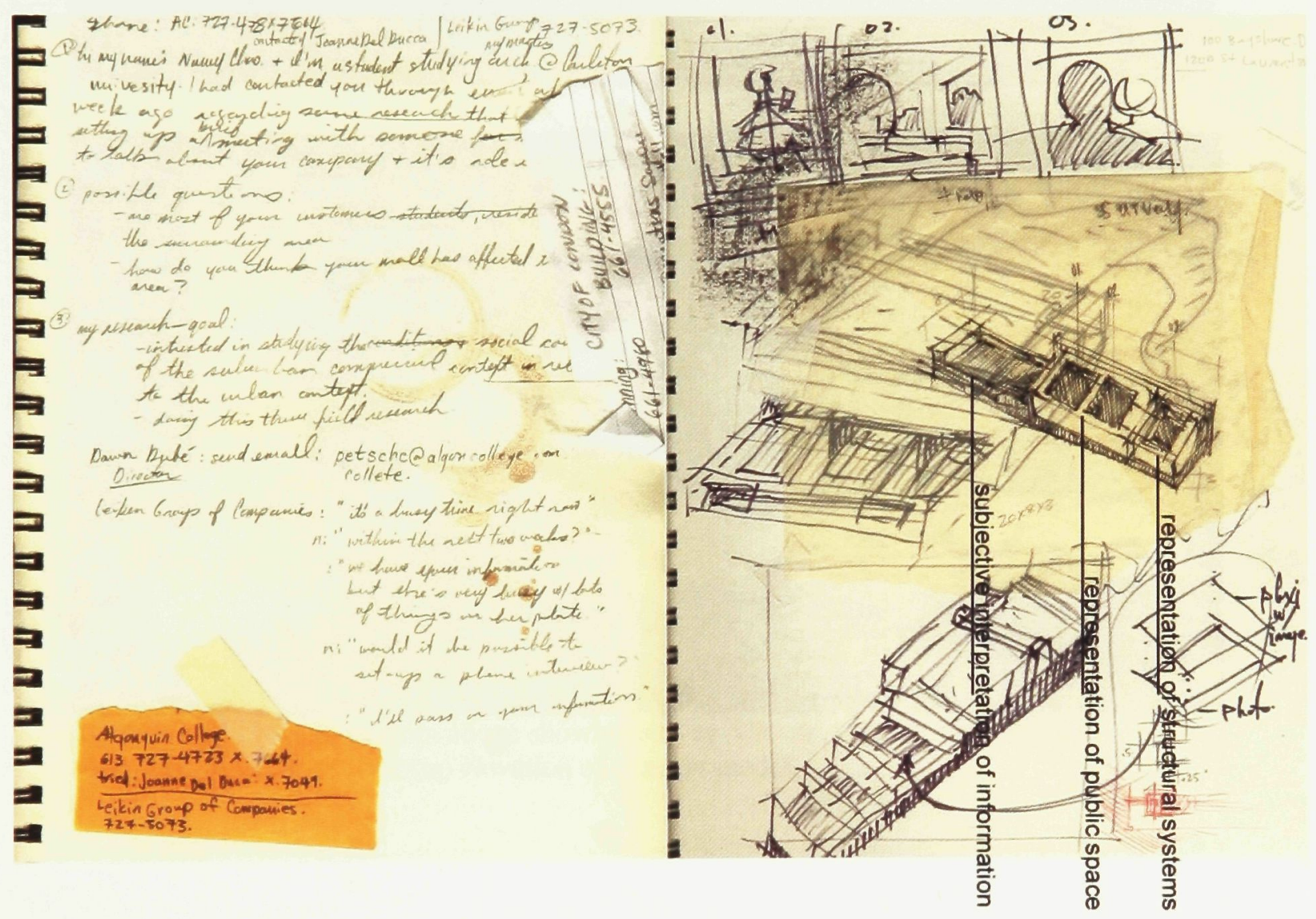

37: sketches for conceptual model 

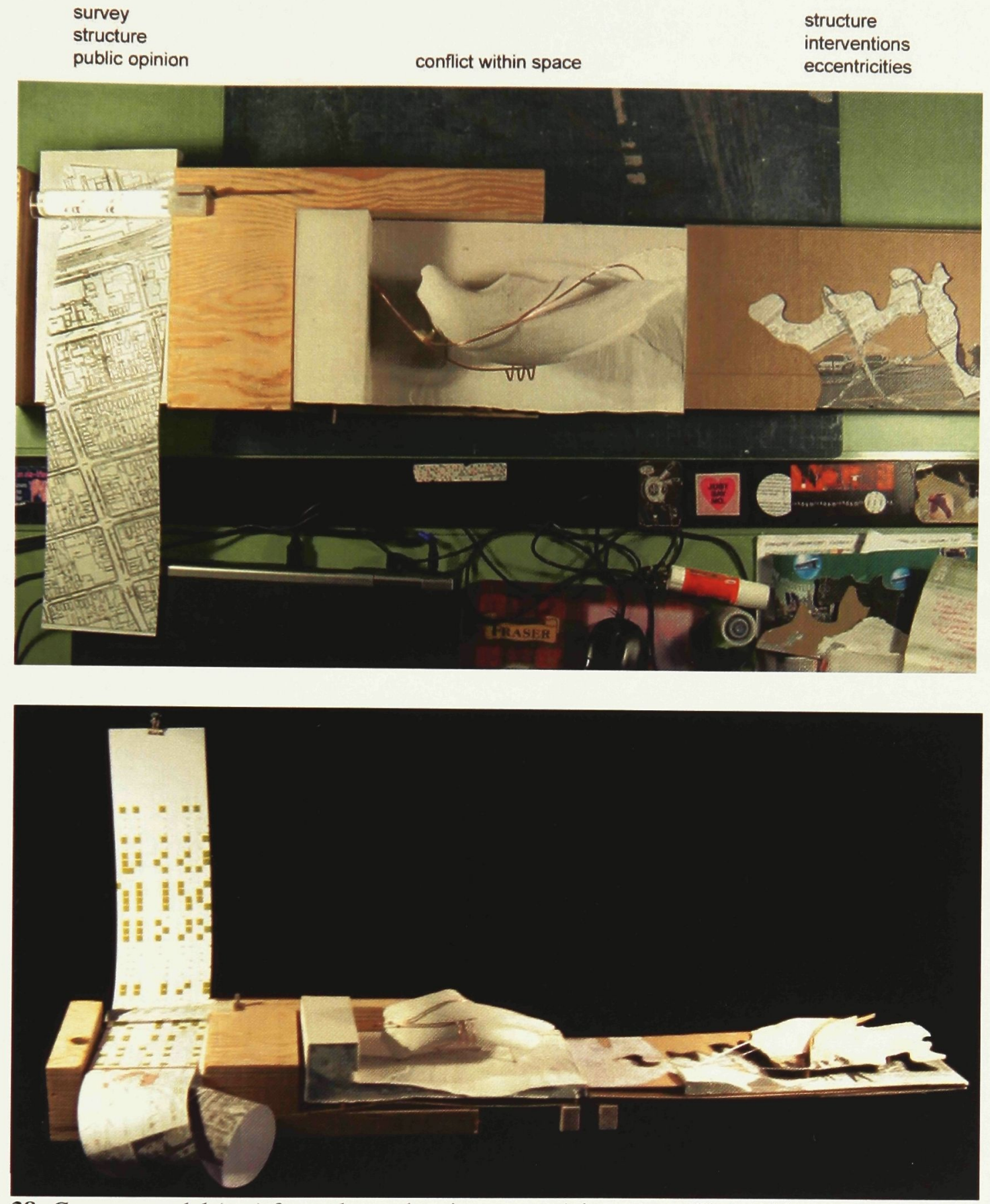

38: Concept model (top) from above showing survey 'viewer', conflict within space, interventions in space (bottom) elevation of concept model. 


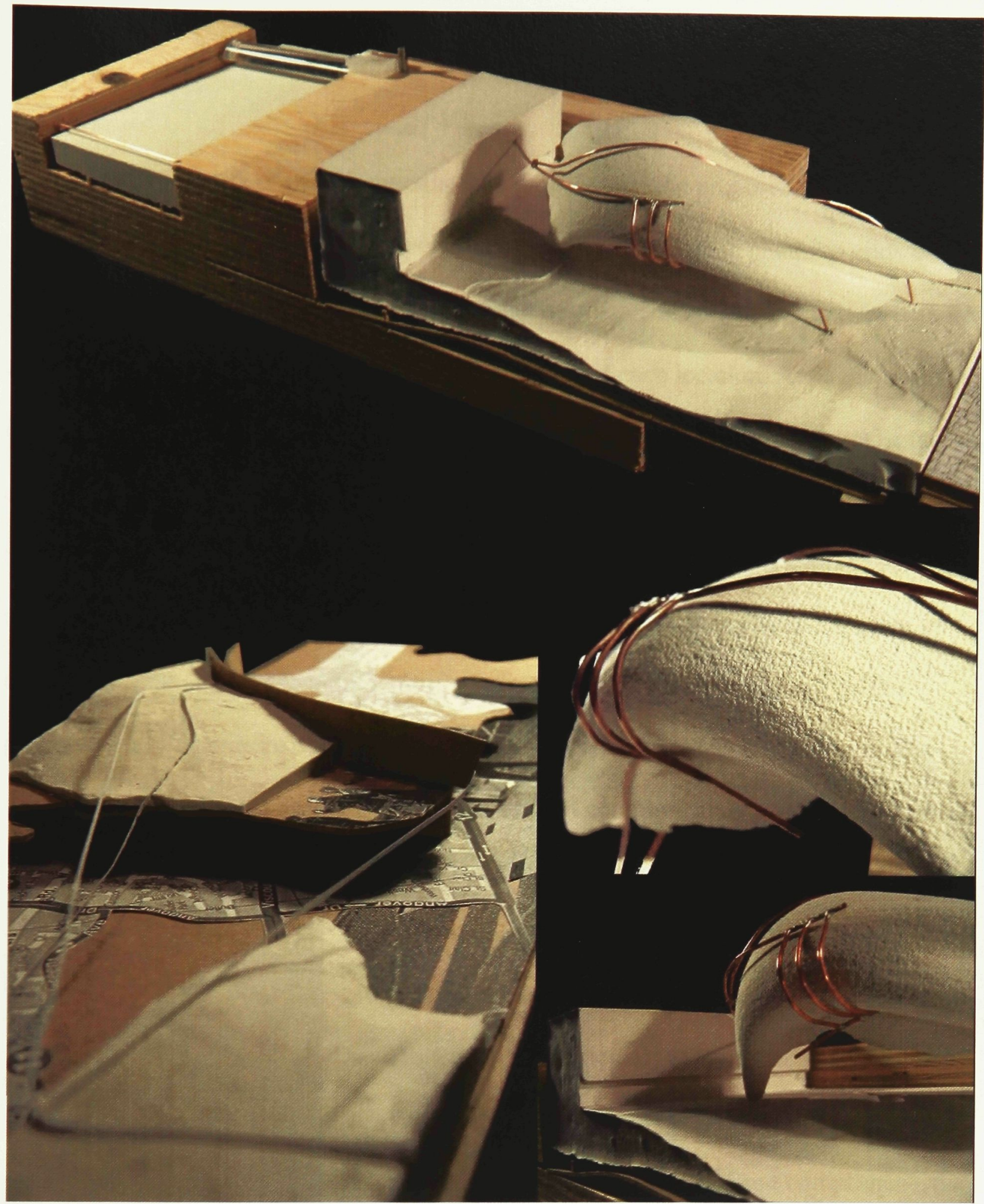

39: details from conceptual model. The plaster cast represents an obstruction in a formal organization. 


\section{Mixed-Use Typology: Sculpting the Phantom Public Sphere}

Within the site of the Westmount Shopping Center, the proposed plan for a multiuse building is based on the superimposition of urban and suburban planning grids and patterns. The use of the grid represents a collage of urban and suburban practices that are critical in informing the unique organizing structures of each location. Acting as a surface for the introduction of residential, office, institutional and public buildings to exist in a complex layering of programme, the potentiality of diverse publics and a new identity for the public space of the suburbs can be discovered. As a building type within the site of the Westmount Shopping Center, the multi-use building strategy occupies the space of the mall as well as its surrounding, mostly vacant, parking lot. The program for the proposed building was inspired from the user surveys conducted as well as the mall's surrounding contextual programmes that can support complimentary programmes within

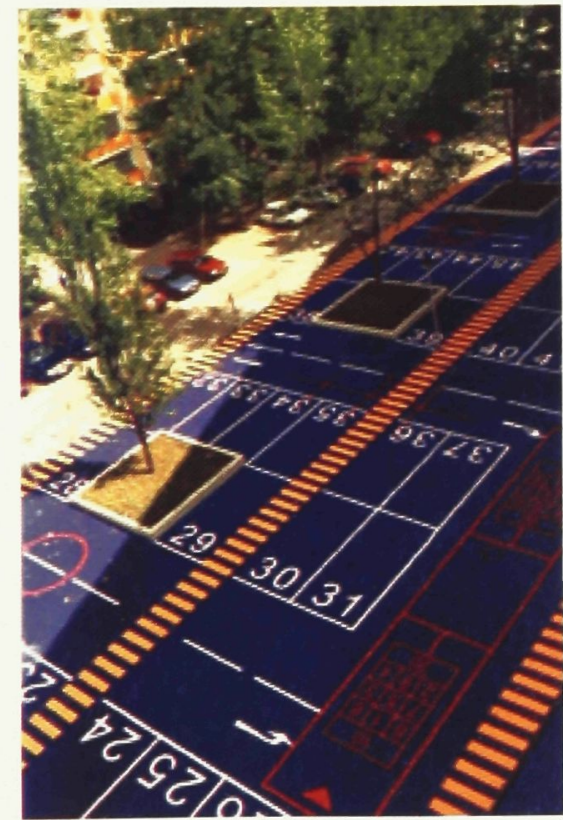

40: looking from above, Buro Kiefer's playground and parking space. the mall. The conventional everyday spaces of the proposed multi-functional buildings include the primary programmatic elements that supplement old, and employ new, functions and structures assigned to the institutions that surround the mall. For example, a community pool is located on the south side of the mall and compliments the programmatic needs of the school district across the street as well as providing a place for residents to engage in water sports and activities.

Landscape Architects Buro Kiefer used 
superimposition as a technique in their design for Flamigstrasse Park in Berlin, Germany, 1998. The outdoor playground delineated the ground plane by using graphic codes to permit multiple uses of a contained area. The coded area combines diverse functions such as parking lot, playground, and sports activity surfaces. ${ }^{6}$ The strategy employed in the initial stages of the new mall plan for this thesis, uses similar techniques of juxtaposition and collage similar to Kiefer Buro Landscape Architects. By choosing to use these different types of codes, alternative representations of space will occur where the hybridization of urban and suburban references will emerge as new relationships between the users of the space and their existing relationship with the public space of the mall. Spaces that are created from the superimposition of spaces engage the site and its users in the making of a democratic and ephemeral public sphere. 


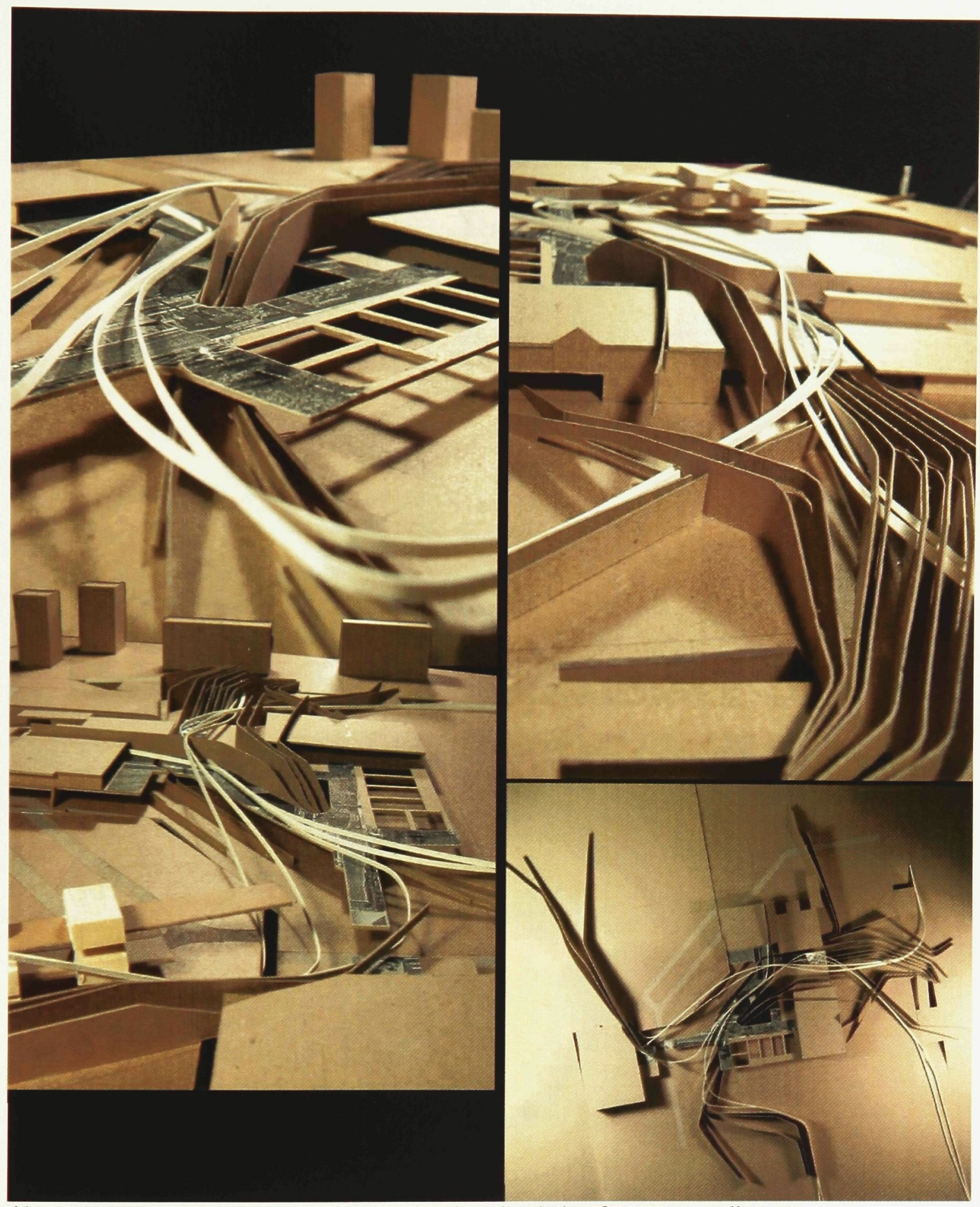

41: model, study of Westmount mall's pedestrian circulation from surrounding programmes 

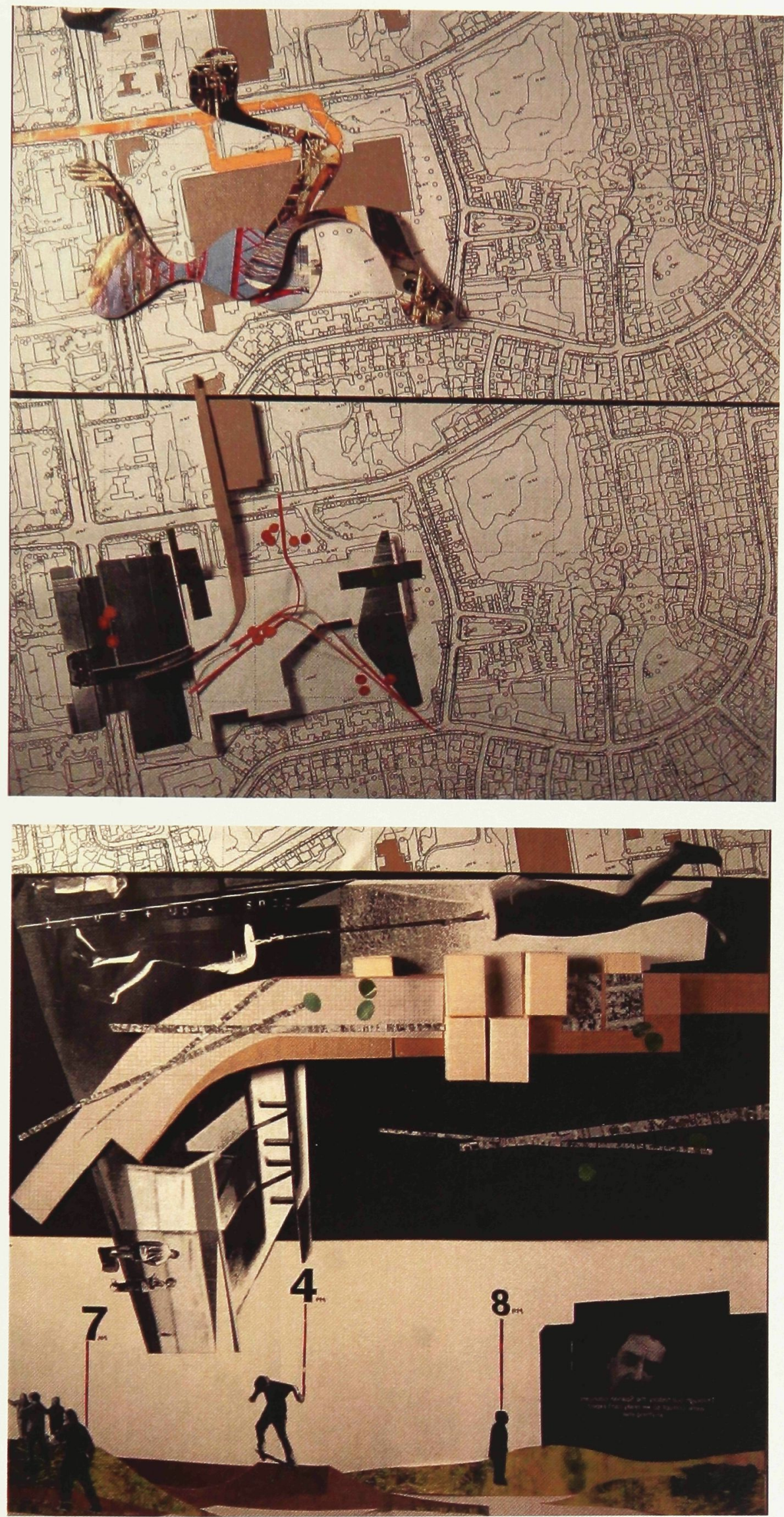

42: collage studies, (top) showing circulation and preliminary programming, (bottom) investigating multi-use surfaces and overlapping programmes. 

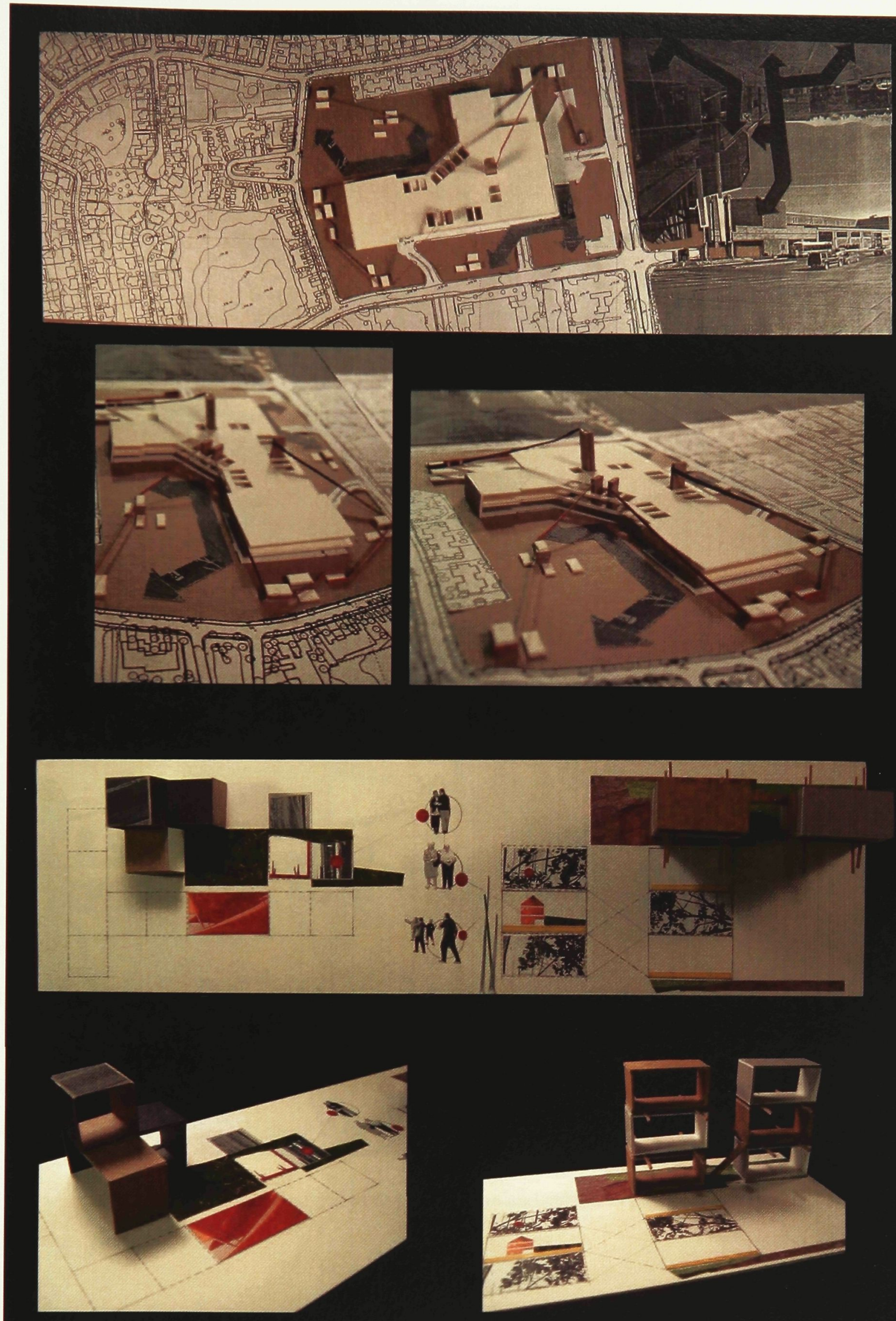

43: collage models, experimenting with shared surfaces for housing units. 


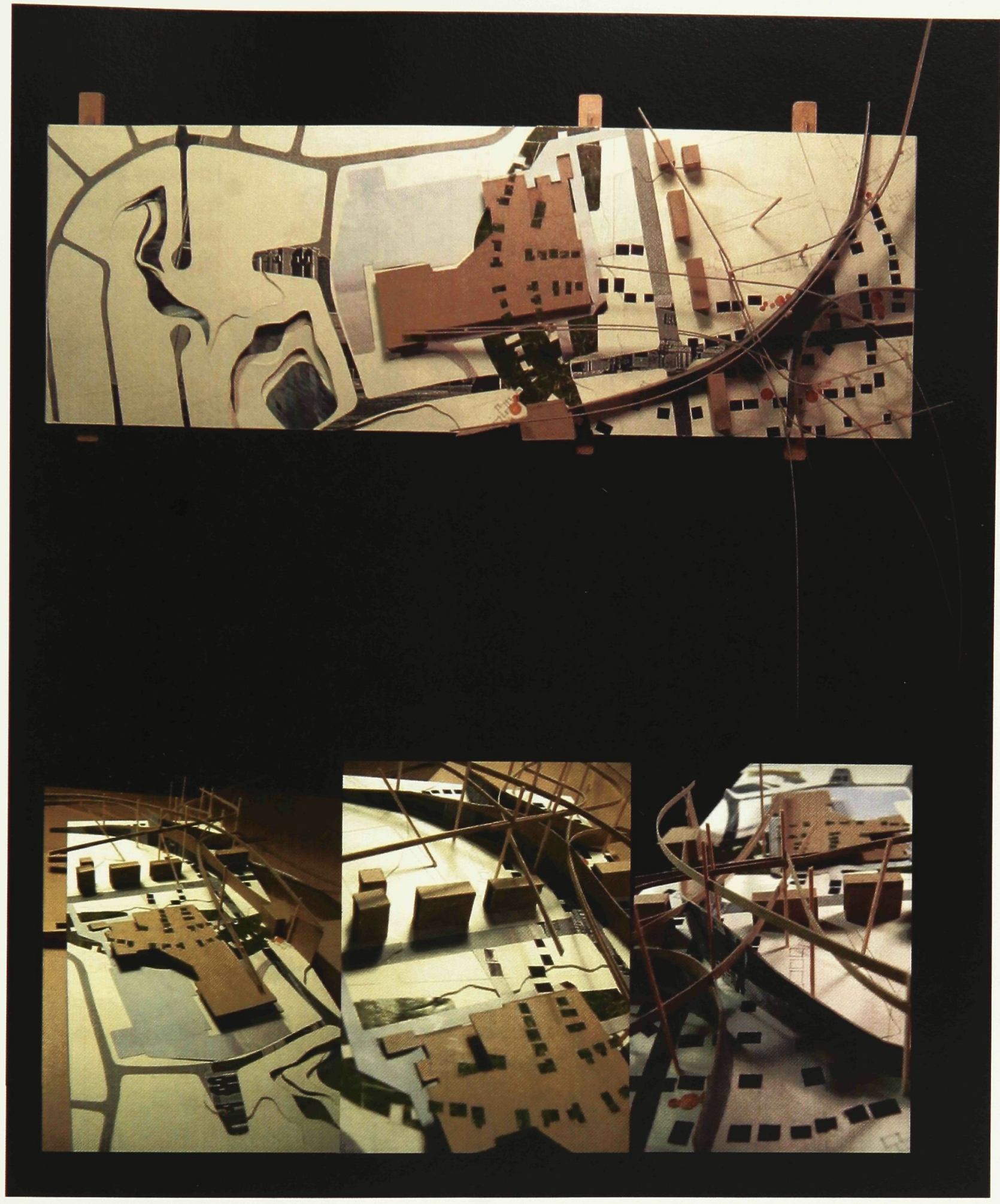

44: collage model study of juxtaposed urban and suburban population and inhabitation densities. 


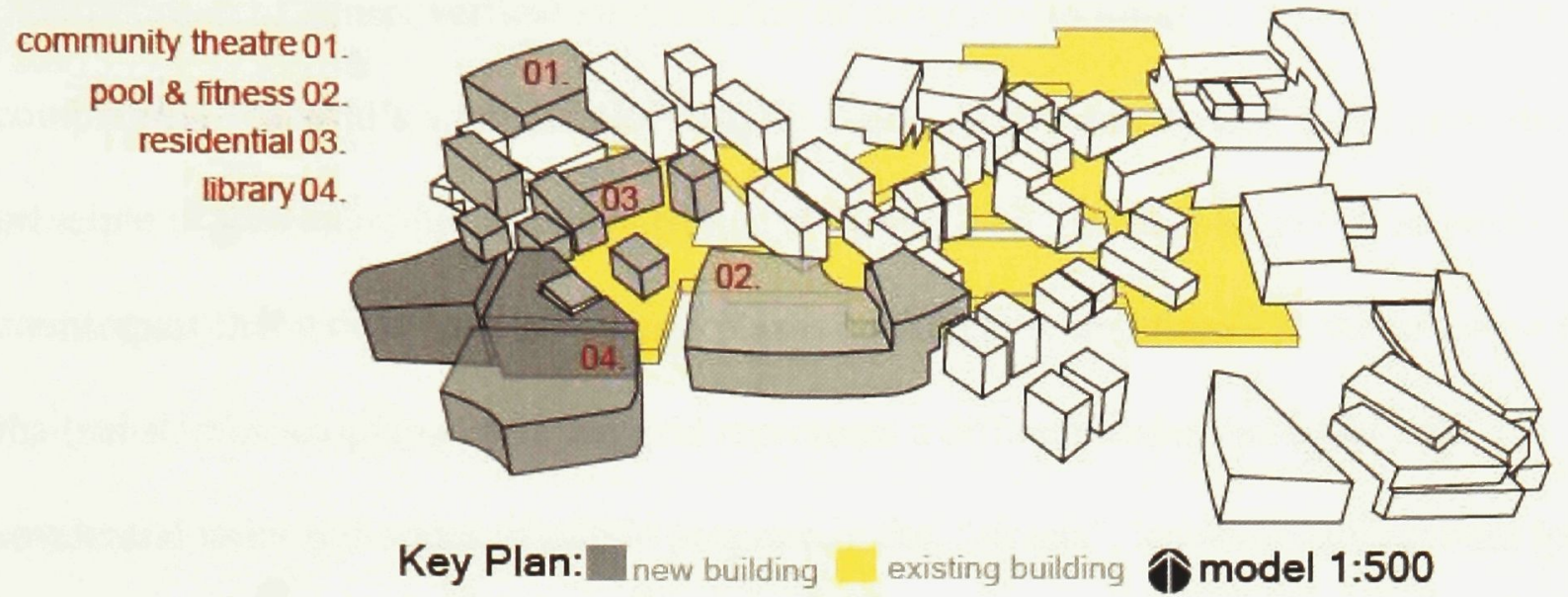

45: Key Plan showing new programme (grey), existing mall (yellow), and other proposed buildings (white).

\section{Programme:}

Existing (Westmount Shopping Centre)

Existing (area of focus as shown in fig. 44)

$$
\text { Library }
$$

Office

$$
\text { Roof landscaping }
$$

Residential (per 1 unit)

$$
\text { Community Pool }
$$

Fitness

Community Centre

Apartment (per single room unit)

Apartment (per double room unit)

\section{Area $\left(\mathrm{ft}^{2}\right)$ :}

60,000

40,000

15,000

10,000

25,000

1,300

6,500

400

5,000

600

1000

The new organizational strategy deployed on the site of the Westmount Shopping centre employs both urban and suburban morphological patterns to guide the design of 
the project. In a typical urban situation, the mapping of a grid on a city generates an abstraction from the existing environment, while increasing connectivity and the incorporation of dense, vertical stratification of programs to improve the city's spatial complexity. The grid's appropriation into the North American city was based upon the principle of free-standing objects surrounded by spaces rather than in their European counterpart that would have patios and plazas encircled by buildings. ${ }^{7}$ In the proposal for the (sub)Urban shopping mall, the grid represents a different order that places the residential units and nodes of public program in the "streets", leaving a central void for landscaping, for public thoroughfares, for parking or for an unexpected appropriation by its users. The void acts as an 'infinite' surface for the Phantom Public to appear since it has no association with any particular programme. Similar Keenan's notion of the Phantom Public Sphere, the void in this instance is a generative term versus that which would suggest a subtraction of place, memory or idea. Through the relocation onto the streets of the reconstructed urban grid, an inversion of the hierarchy of characteristics inherent in the 'street-space' that typically serves as the public space of the city now blends into the privatized spaces of the (sub)Urban grid. Unlike Le Corbusier's urban grid, the proposed grid, which is located on top of the mall's roof, preserves characteristics of public qualities in two ways. Firstly, the new (sub)Urban grid integrates and blurs the public and private boundaries through the physical injection of private homes into the space of the mall. The ground level of some of the "work/live" residential units are contained within the second level of the mall, therefore allowing the house to be 'suspended' between the public space of the mall itself and the semi-private space of the residential roof. The new semi-private datum is located on the roof of the mall but the 
interjections into the mall stimulate the public to interact with and respond to the unusual boundary conditions presented by the houses. The residential grid is oriented along the existing mall's main circulation corridor. Secondary pathways from the mall's original corridors of pedestrian circulation extend into the exterior of the mall creating another, new, organizational system within the existing parking lot. Different permutations of the extended corridors include canopies, pathways, signage or codes such as physical thresholds. These secondary pathways are critical in the circulation of the site and its surrounding context. The influx of pedestrians from the schools, residential areas and apartments have a consistent routine that the new proposed building responds to with the making of threshold spaces in-between, under and over new spaces, public building interventions, or pathways.

The second way in which the new grid assumes fluid public attributes can be discovered in the typology of the housing units. The proposed houses are based on the single-family suburban home. While the floor area of the new houses is similar to that of a typical suburban house the proposed prototypes for the new building are composed of a combination of single unit houses and shared housing typologies. The housing units share office space while an undulating surface defines the walls and rooflines of each house. The unifying surface of the wall insinuates a sense of layering and overlap between the users of the house that is revealed in an interior shared space. The density of the new housing multiplies that of the existing suburban fabric. The garden and green space of the units are contained within the buildings themselves as roof or interior gardens. The new datum created on the top of the mall is an undulating organic roof punctuated by houses. 
The landscaped roofs can be used by the residents as pathways, playgrounds, and places of gathering, and are fully accessible to the public.

The institutional buildings directly correspond to the context in terms of modes of circulation and existing programmatic site conditions. The introduction of a community theatre located in the northwest corner of the mall close to the residential area complements the area's passive disposition. The community theatre shares its stage with an exterior platform that serves as an alternative outdoor stage. The transfigurations of the wall-panels that face the mall open to reveal the interior of the building to a public platform. Similar to sliding doors found in homes, the wall panels act as temporary screens to separate or open space. When closed, the wall acts as a screen that divides impromptu from rehearsed entertainment.

Other new programmes which were inserted within the site include a new outdoor theatre, a relocated bus terminal, apartment buildings, car washes, office space, community gallery, unallocated space for rent, restaurants, and large venues for big-box stores. The extension of space is a prominent theme that is used throughout the building strategy. Other codes associated to the mall such as floor tiling and building structure extend to the exterior of the building taking a new form as landscaping and housing structure, respectively. Shared private space allocated to the apartment building's inhabitants, is bisected with public pathways that connect with the public realm and frame activities and events that characterize the mall. Other programs include a swimming pool and local library planned for the southwest area of the mall, which support and supplement the existing educational institutions located across the street. The methodology for the establishment of civic buildings around the area of the shopping 
center, adopts the use of suburban street patterns which could be superimposed onto, or placed under and around, the mall. The areas that the public buildings inhabit reflect the aggregate consumption of land that the suburban homes occupy. The inversion of functions that these superimposed organizational structures create are dynamic environments for which the Phantom Public can find use. Since the public space is contained within the parameter of the enclosed shopping centre, smaller externalized residential units can be extended into the territory of the mall. 


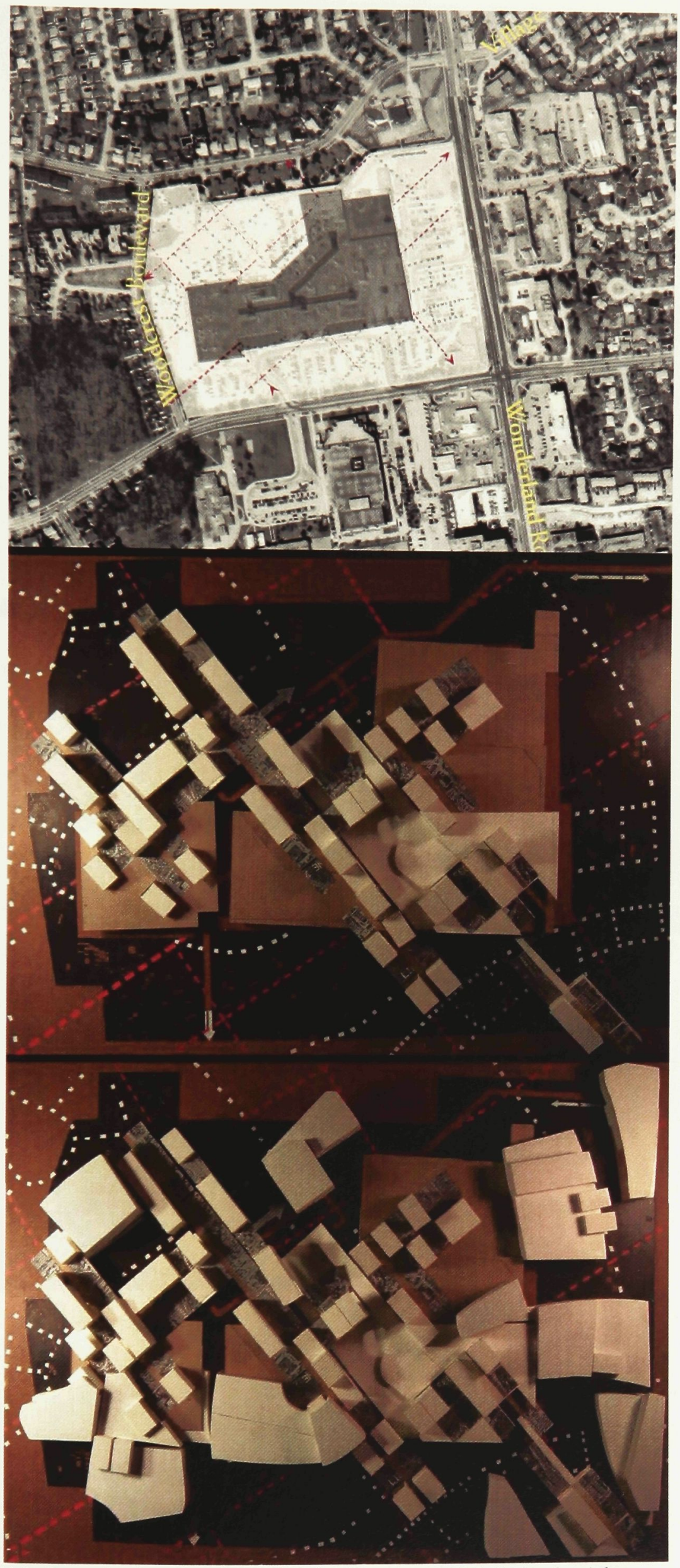

46: Organizational strategy for the Westmount Mall site,(top) key plan showing site and surrounding area, (middle) showing residential massing grid, (bottom) showing public buildings based on suburban plans. Model scale: 1:500 

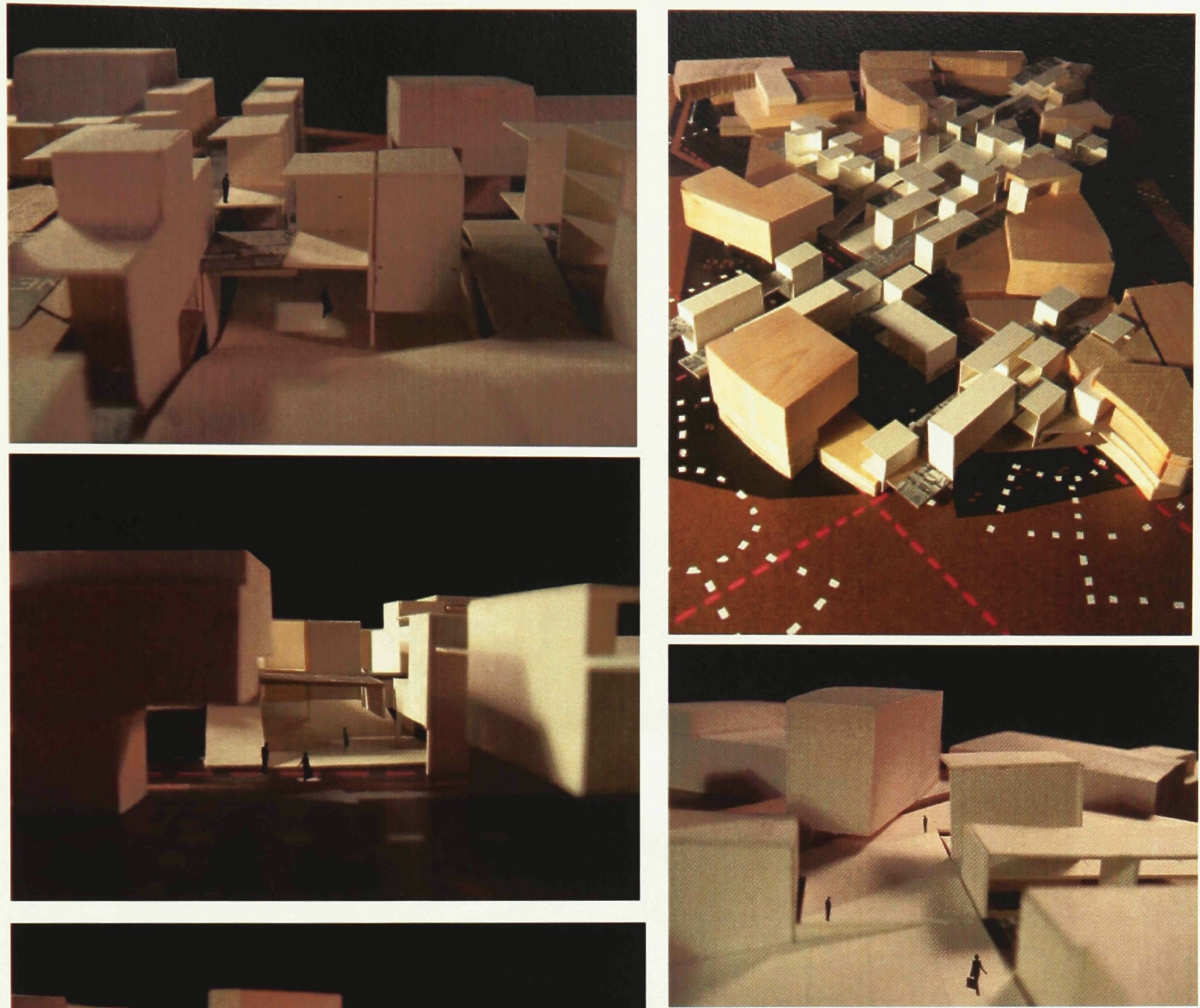

47: Organizational Model showing details of layered spaces. 


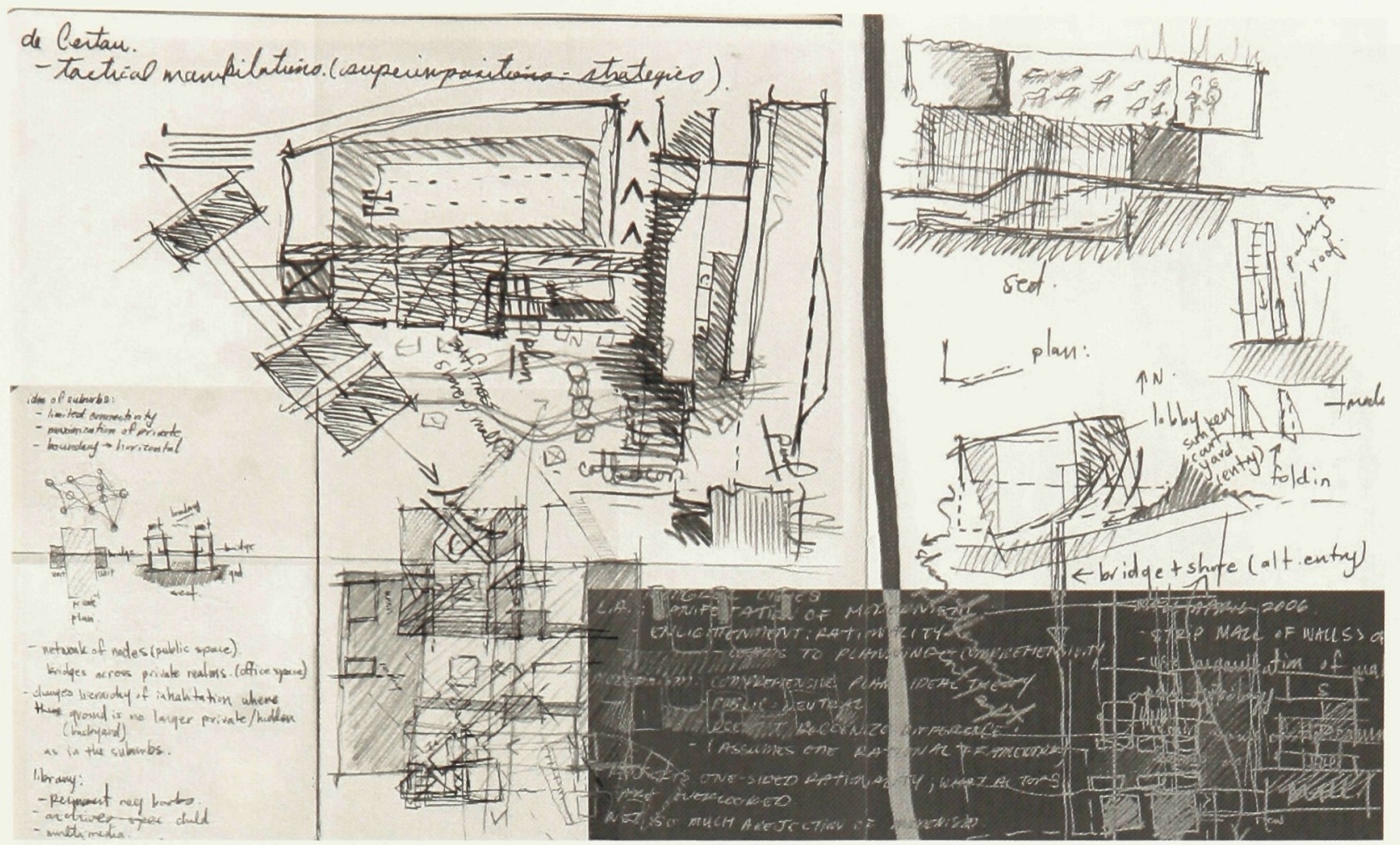

48: preliminary sketches for multi-use programme.

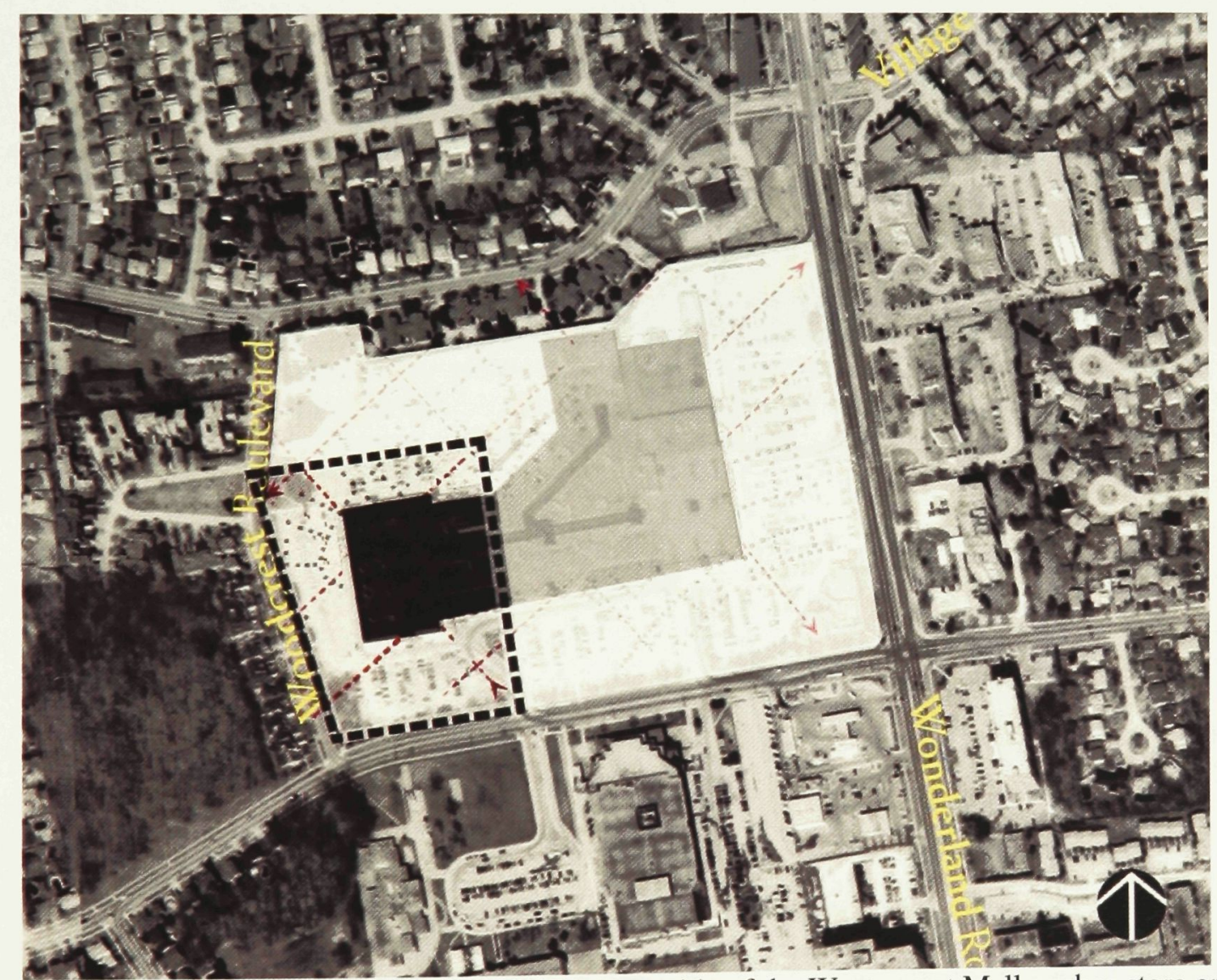

49: Key plan for 1:200 model, area of investigation: westside of the Westmount Mall anchor store and parking. 


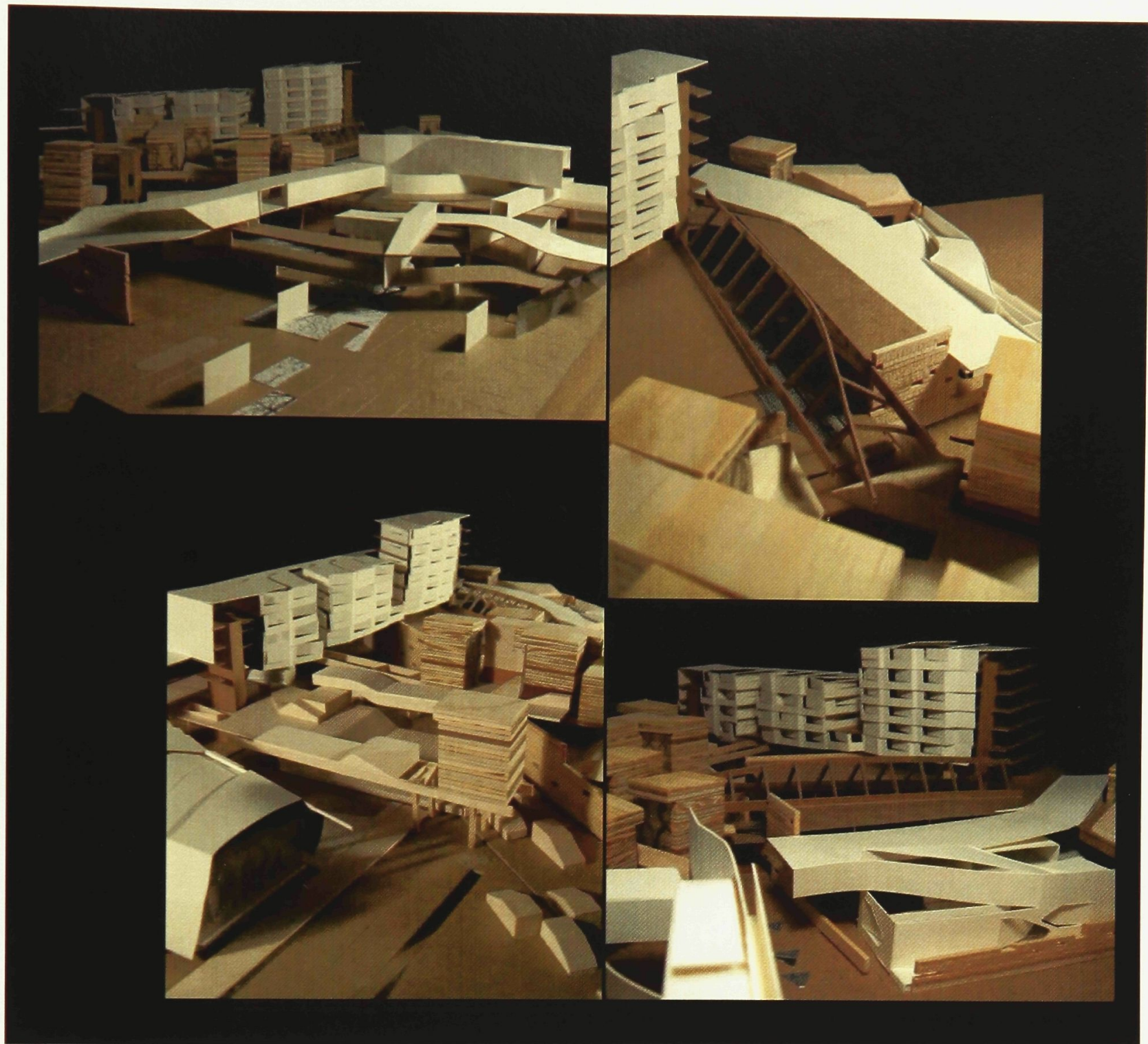

50: model showing architectural intervention on the south-west anchor of the Westmount Shopping Centre. Clockwise from top left: showing southeast corner library intervention, manipulated skylight and housing, showing apartments, housing, theatre and path to mall, bottom right: showing pool, library and apartments. 


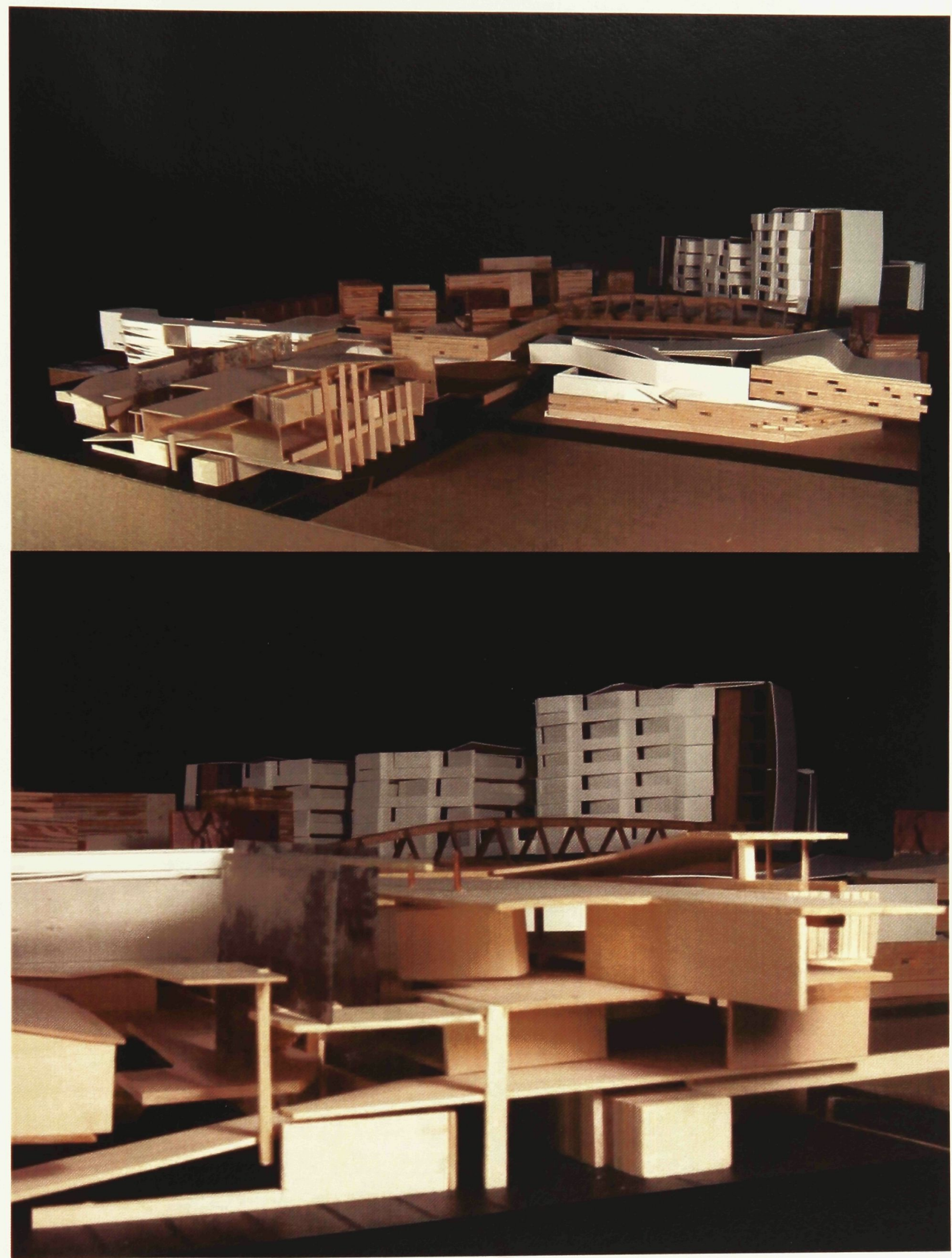

51: (top) Looking at South Facade, (bottom) Looking at library. 


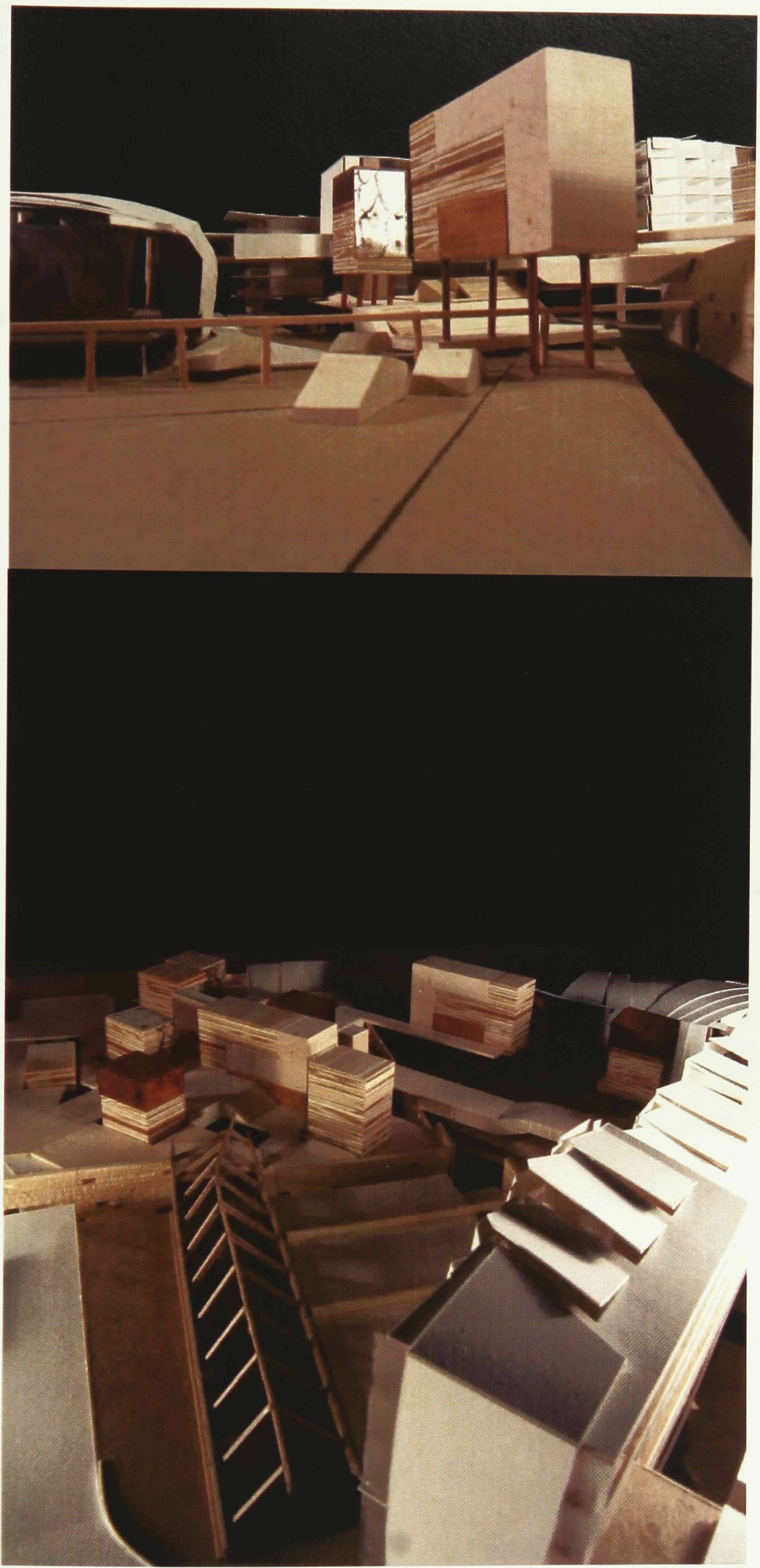

52: (top) North entrance, (bottom) Looking west above apartments and residential. 


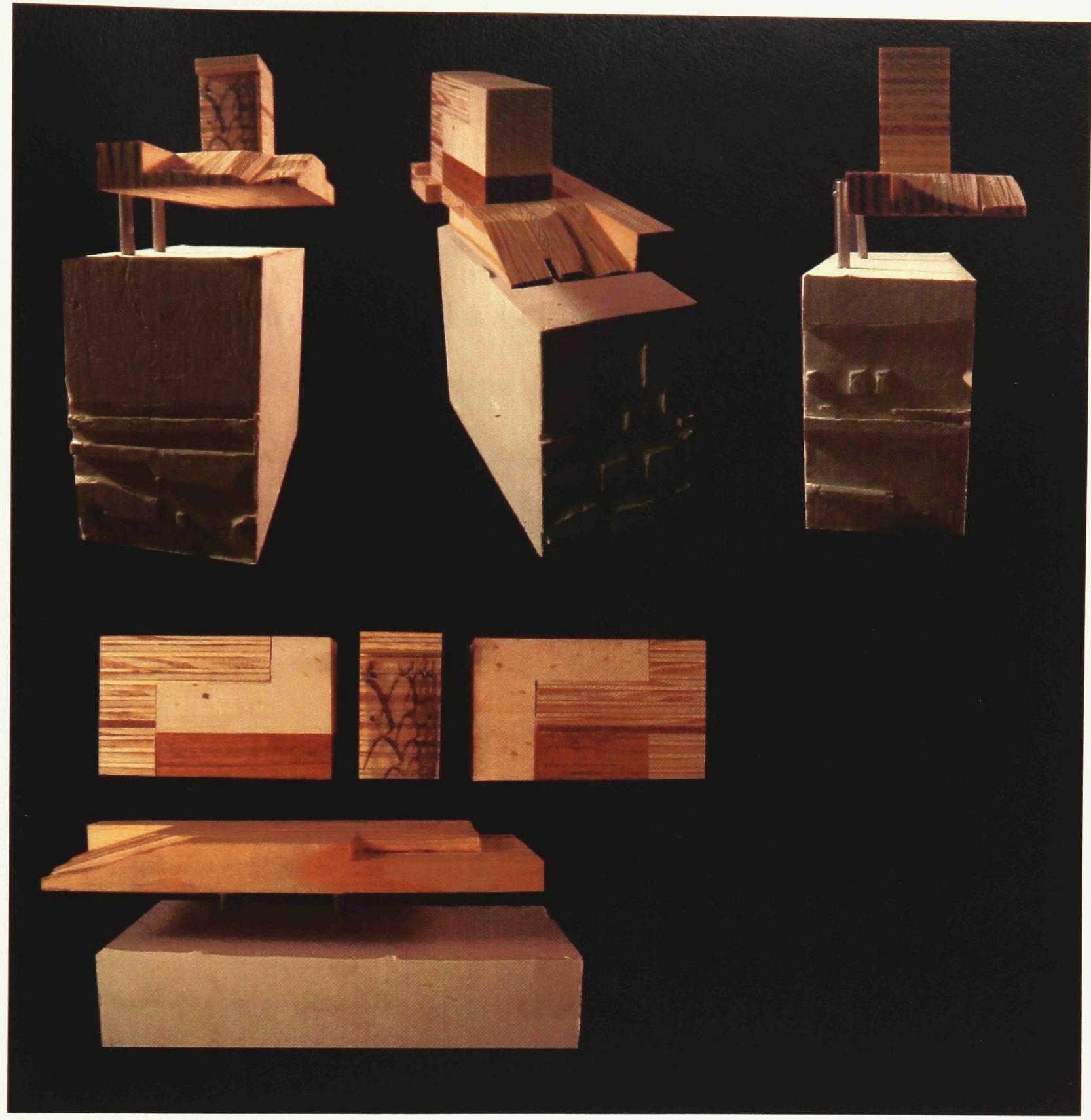

53: House modules showing three types: duplex and single. 


\section{$\underline{\text { Materiality }}$}

The materials of the private and public buildings are based on a variation of urban and suburban conditions. The private houses use traditional materials such as wood and brick, echoing the urban typologies of the downtown core. Although different in form, the buildings propagate a familiarity and memory of place which their users can relate to. As a prototype, the front of each house is made up of a three-panel system of transparent material that includes, from the interior to exterior, movable solid walls, a glazed wall, and mesh chain-linked curtains. Located on the exterior façade of the building, the mesh refers to the chain-link fence that is typically used to demarcate the boundaries of the private space of suburbs. The paneled wall system allows the user to manipulate the interior environment to determine the degree to which it interacts with the external environment. The exteriorization of interior relationships by way of transparency and shared 'green' space reverses the typical organization of a typical suburban home, isolated and private, and creates a dialogue with its environment - a duality between the private and public realm. It prioritizes the creation of public space and acts as a screen to allow varying degrees of intimacy with the other inhabitants and their greater context.

Some of the public buildings penetrate the existing shopping centre to act as new apertures in the exterior of the blank façade. The exterior building systems are derived from the plasticity and prefabrication found in the suburban landscape. As modular assemblies, they are pieced together to compose a fragmented interlocking façade that frames the activities in the interior of the building for pedestrians and for motorists 
outside of it. The duality of the spaces and relationships in the new suburban landscape constructs a contingency of events and activities that responds or corresponds to the activities and events which occur within the multiple layers of space. 

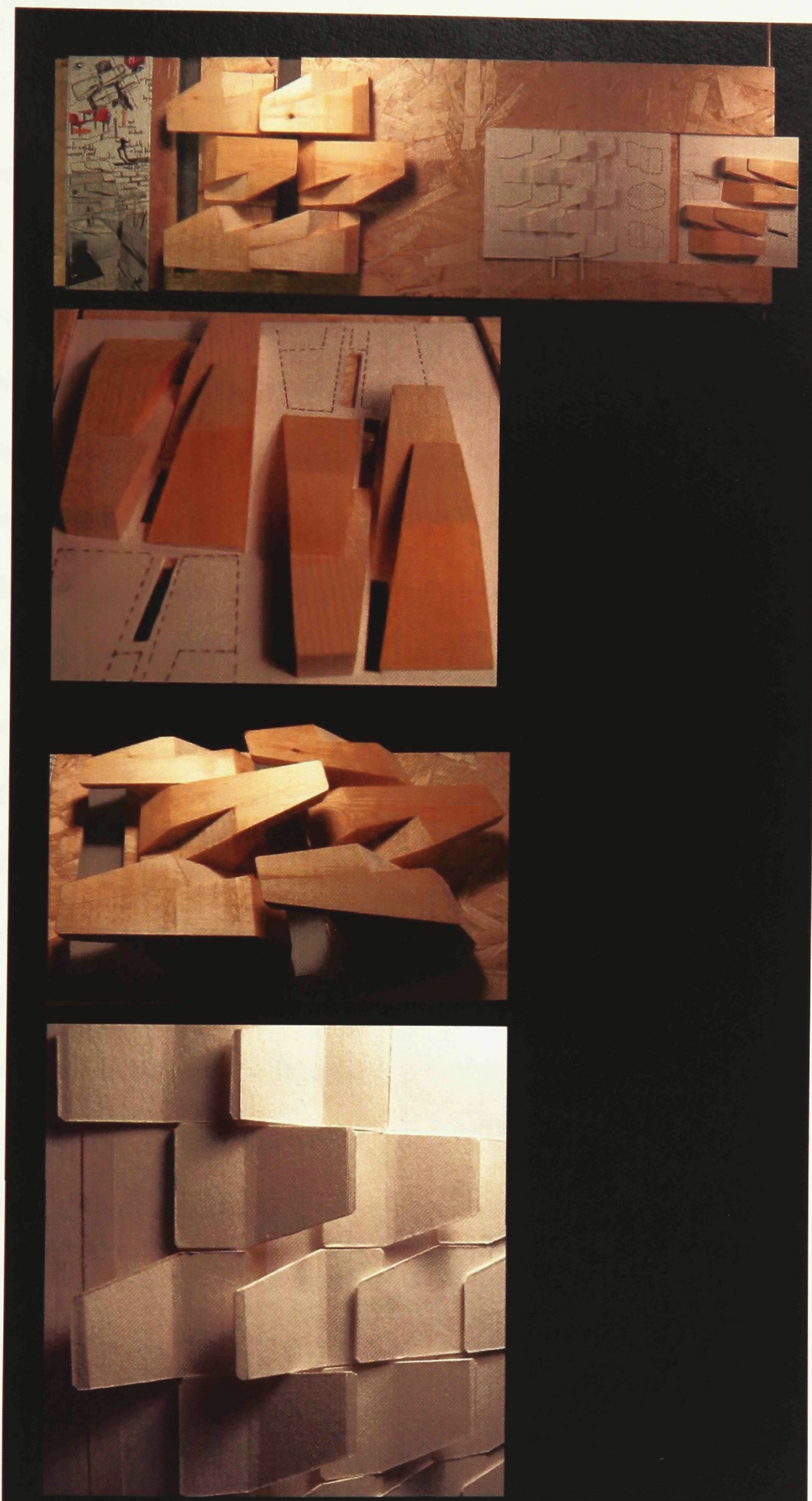

54: modules, brick and fibreglass molded units for houses and public buildings, respectively. 


\section{Library: A Dialogue of Public Space}

The library mediates between the mall and the schools located across the street. During the summer the school district is virtually empty, creating a void in the fabric of the suburban landscape. The placement of a library in the parking lot plays on the integration of the conventionally automated and media dependent society of the suburbs. The presence of the library on the space of the parking lot assumes a shift in the hierarchy of mall space. As an intervention, the library acts as a conflictual programme that is not normally associated with the commercial activities of the mall. Upon entering through a landscaped park, the user traverses a collage of textures and materials that are overtly synthetic and organic. The ground floor of the library mimics the organization of the parking lot. Study carrels line the perimeter of the building aligned along spaces automobiles once occupied.

The surface of the parking lot extends into the ground level of the library creating a new surface for the library and acting as a trace of its former function. The second level contains reference material set within the walls of curvilinear spaces. These curvilinear bars are suspended two storeys above the vehicular roads and bridges across the main roadway to encircle a forested space below. The penetration of the bars into the existing space of the mall juxtaposes the areas of work, leisure, and education. As a generative process the library uses the existing organizational structures of the mall to manifest a space that is different from that of the operations of the mall. By redefining known symbolic representations and operations of the mall; the library becomes associated with a differentiated public that is in dialogue with the users of the mall. The identity of the 
library is not a consumer space and by creating dialogue with consumer space it affects the way in which consumers re-evaluate personal identities that they acquire in the mall one that is not strictly based on consumer goods.

The renewal of the suburban mall as a manifestation of the superimposition and collage of symbolic typologies induces ambiguous and indeterminate spaces for the possibility of transforming them to Phantom public space. The multiplicity of the spaces and the incidental interaction between the public and private realms challenges the existing hierarchy of privatized "public" space in the suburbs. 

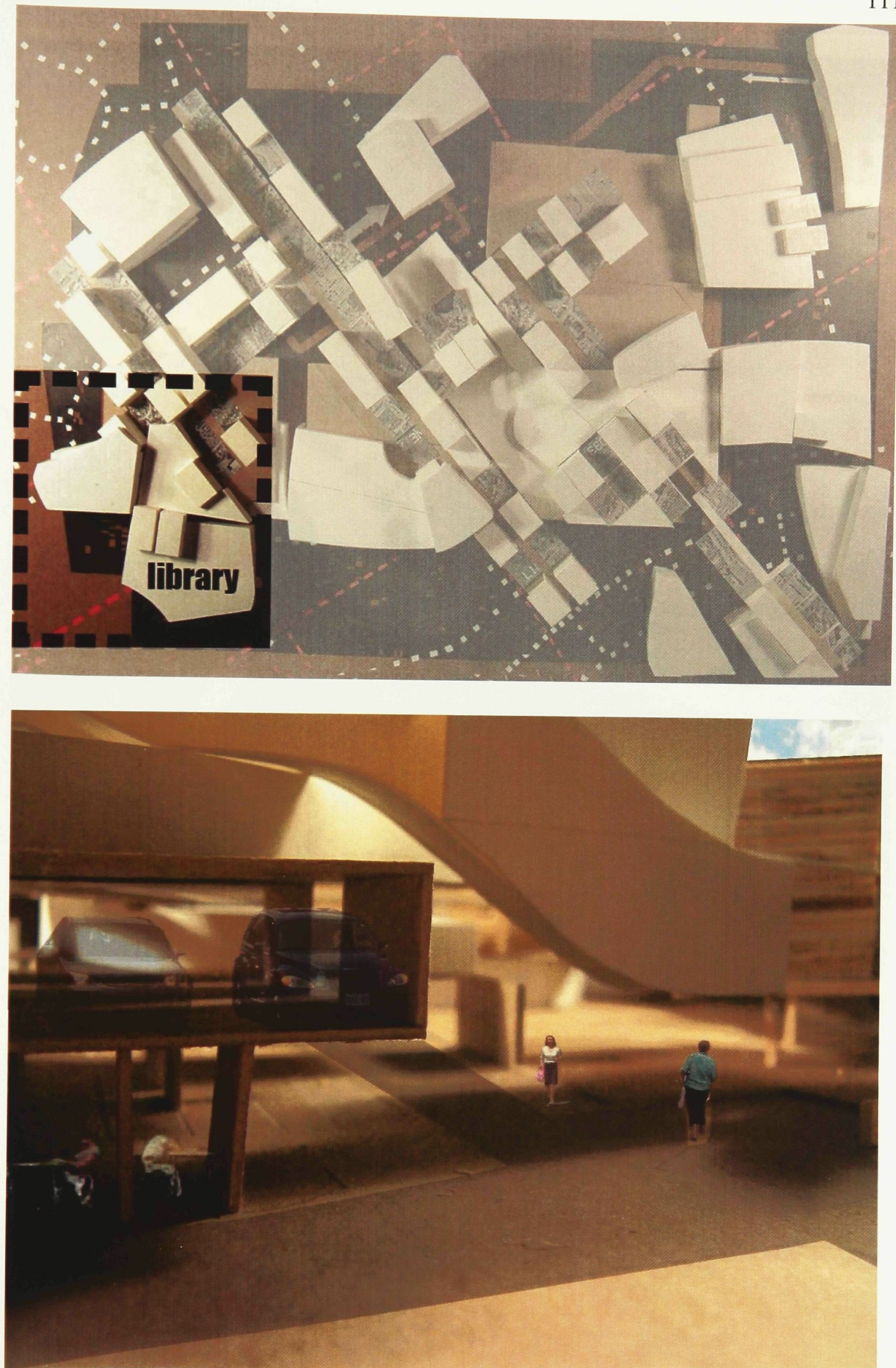

55: (top) showing key plan of the library within the Westmount mall context, image showing library across from the Zeller's entrance, looking west. 


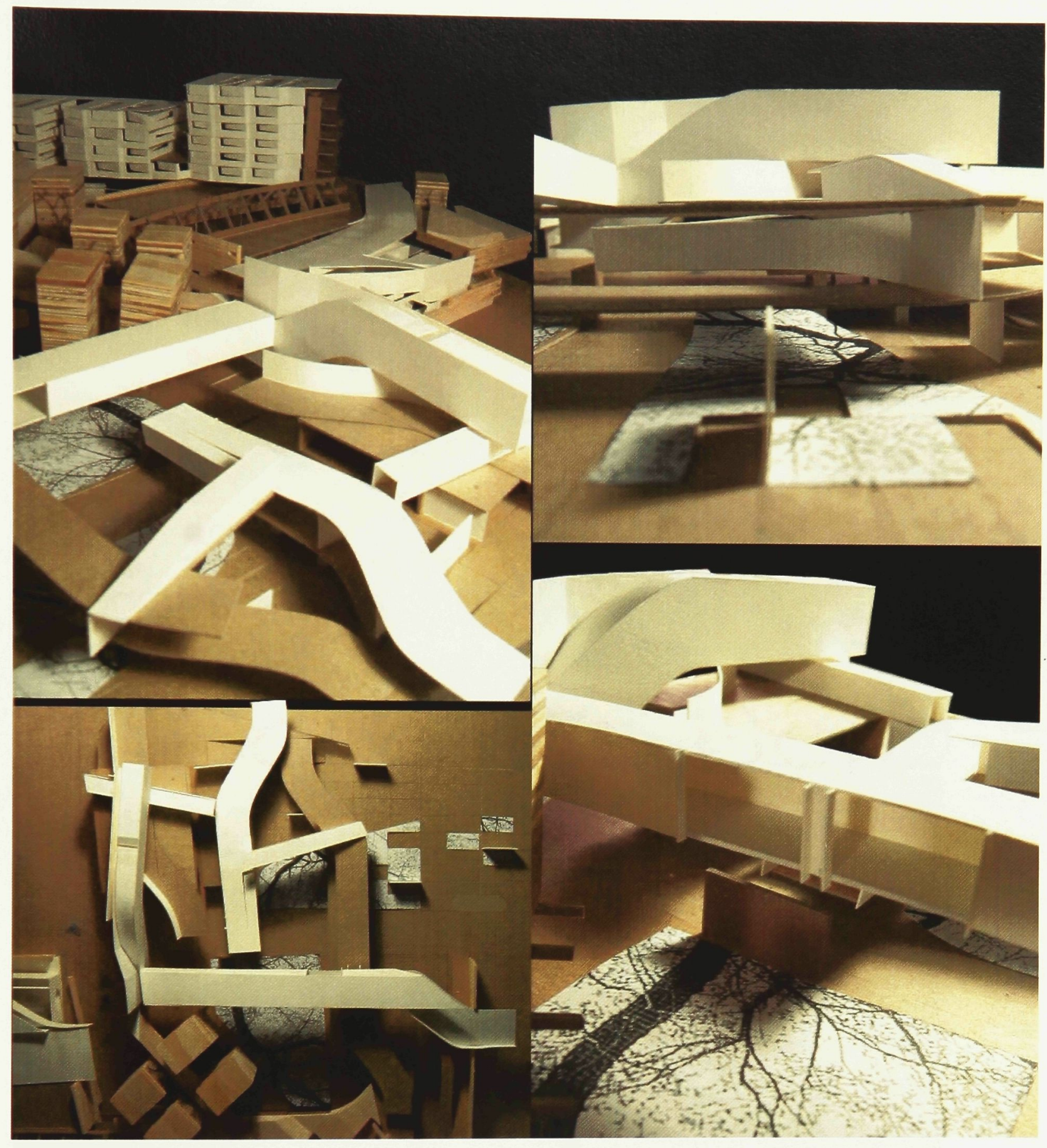

56: constructing the library. 


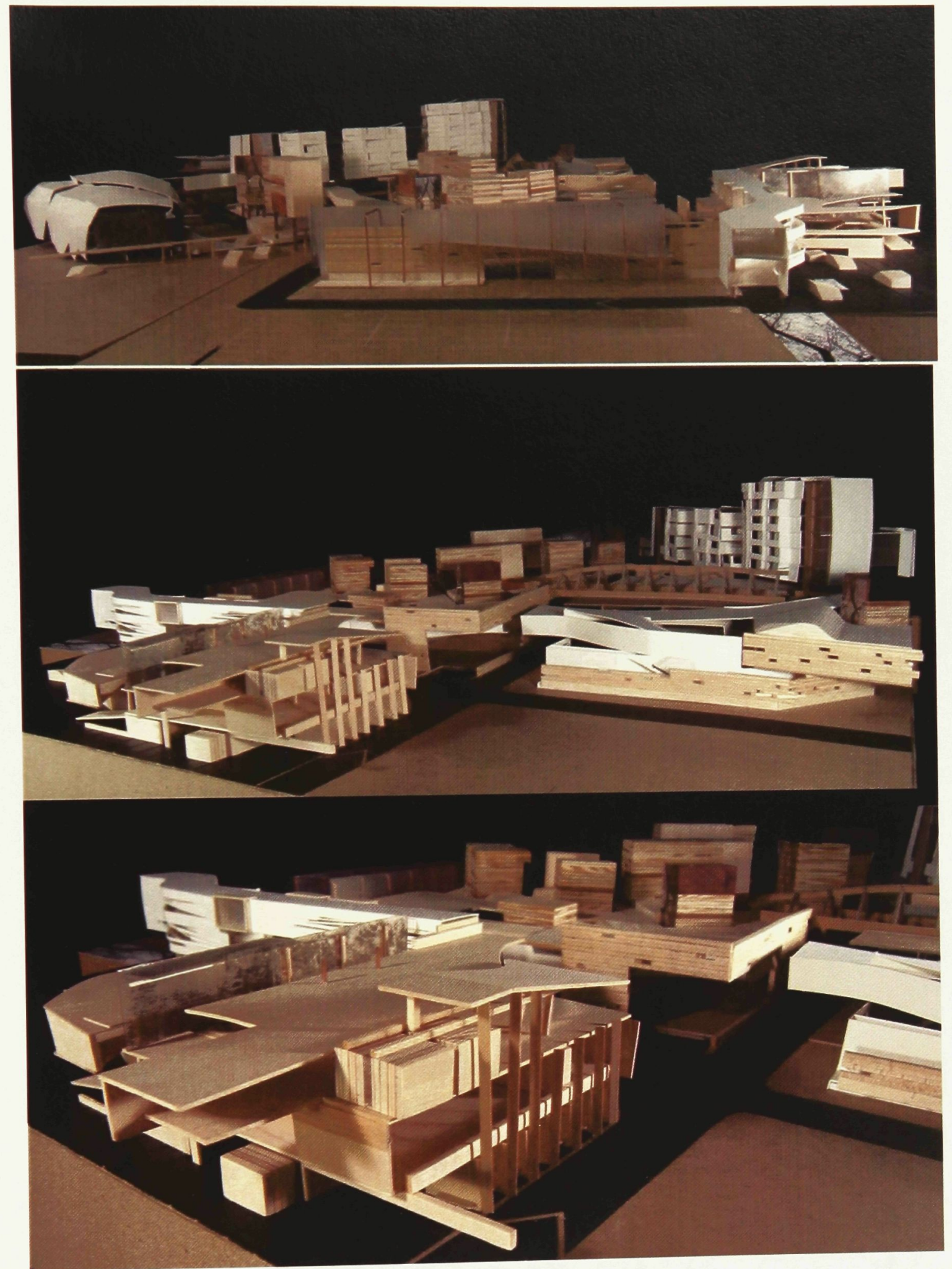

57: library elevations. 


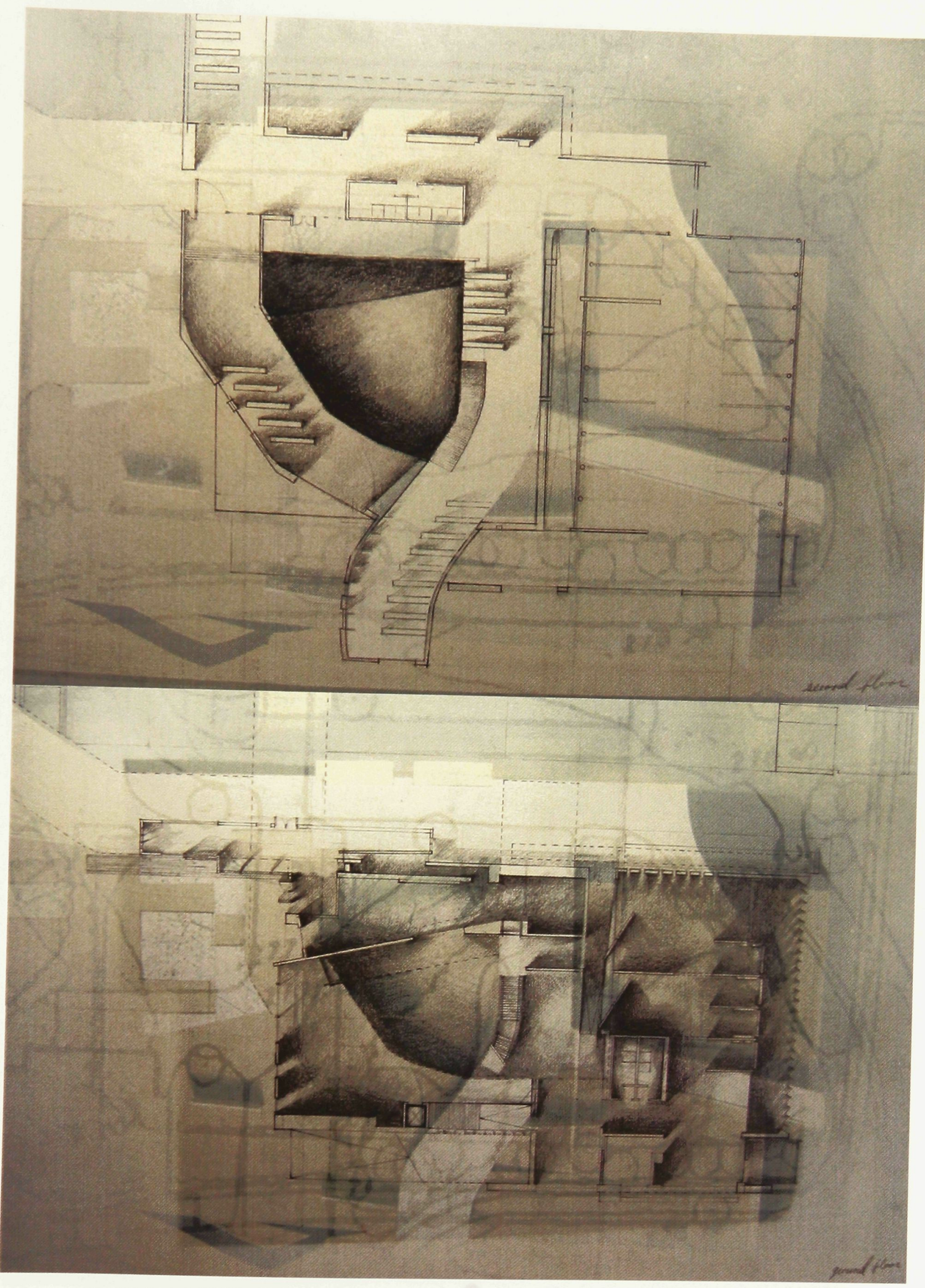

58: (top) Second floor plan, (bottom) First floor plan. 


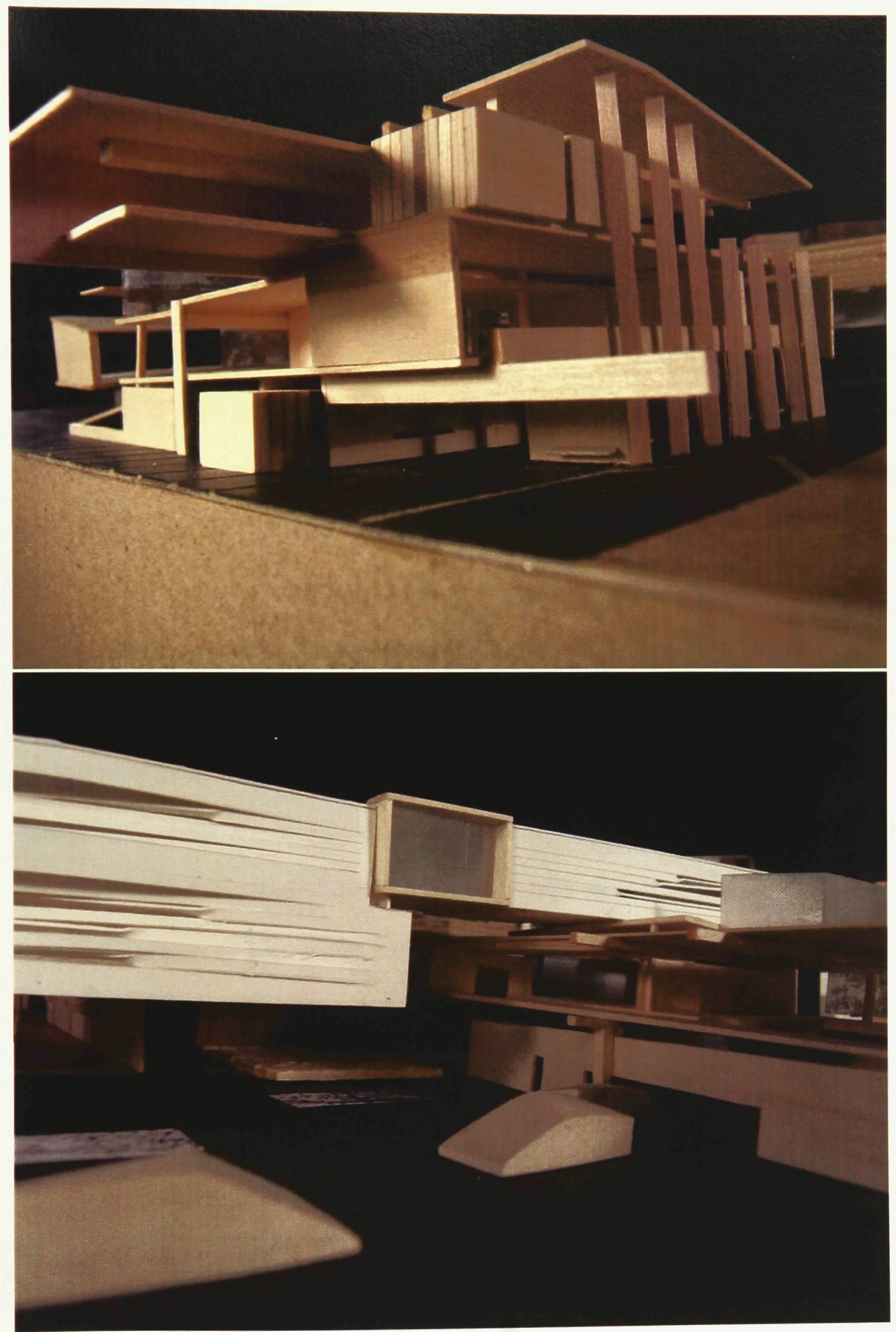

59: library (top) study carrels, (bottom) office space above and library entrance. 


\section{Appendix A}

\section{Suburban Shopper's Survey}

\section{$\underline{\text { Survey Procedures }}$}

This survey used a random selection of 38 anonymous shoppers at the St. Laurent Shopping Centre in east Ottawa, Ontario. The surveys were conducted over two days, one day during the week and one day during the weekend. The shoppers were asked questions which ranged from their shopping routines to their opinions about the mall's identity in their neighbourhood.

The St. Laurent Shopping Centre is a family oriented shopping center with plentiful seating areas along the pedestrian routes inside the mall. The two storey structure houses a large above-ground parking structure along the eastside of the mall and ground level parking around the rest of the mall. Also serving as a major public transportation node, the St. Laurent Mall is a convenient shopping location for regular bus-users in Ottawa. Nearby institutions such as high schools and elementary schools exist and a variety of apartments, single-family homes and row-housing populate the mall area. It's close proximity to the main arterial roadway, the 417 highway, also lends itself to convenient automobile access.

\section{$\underline{\text { Results }}$}

The following table shows a summary of the questions asked to each participant.

\begin{tabular}{|l|l|l|}
\hline Number of male respondents & 15 & \\
\hline Number of female respondents & 23 & \\
\hline
\end{tabular}

Question No.: $\quad$ Question: Answer: 


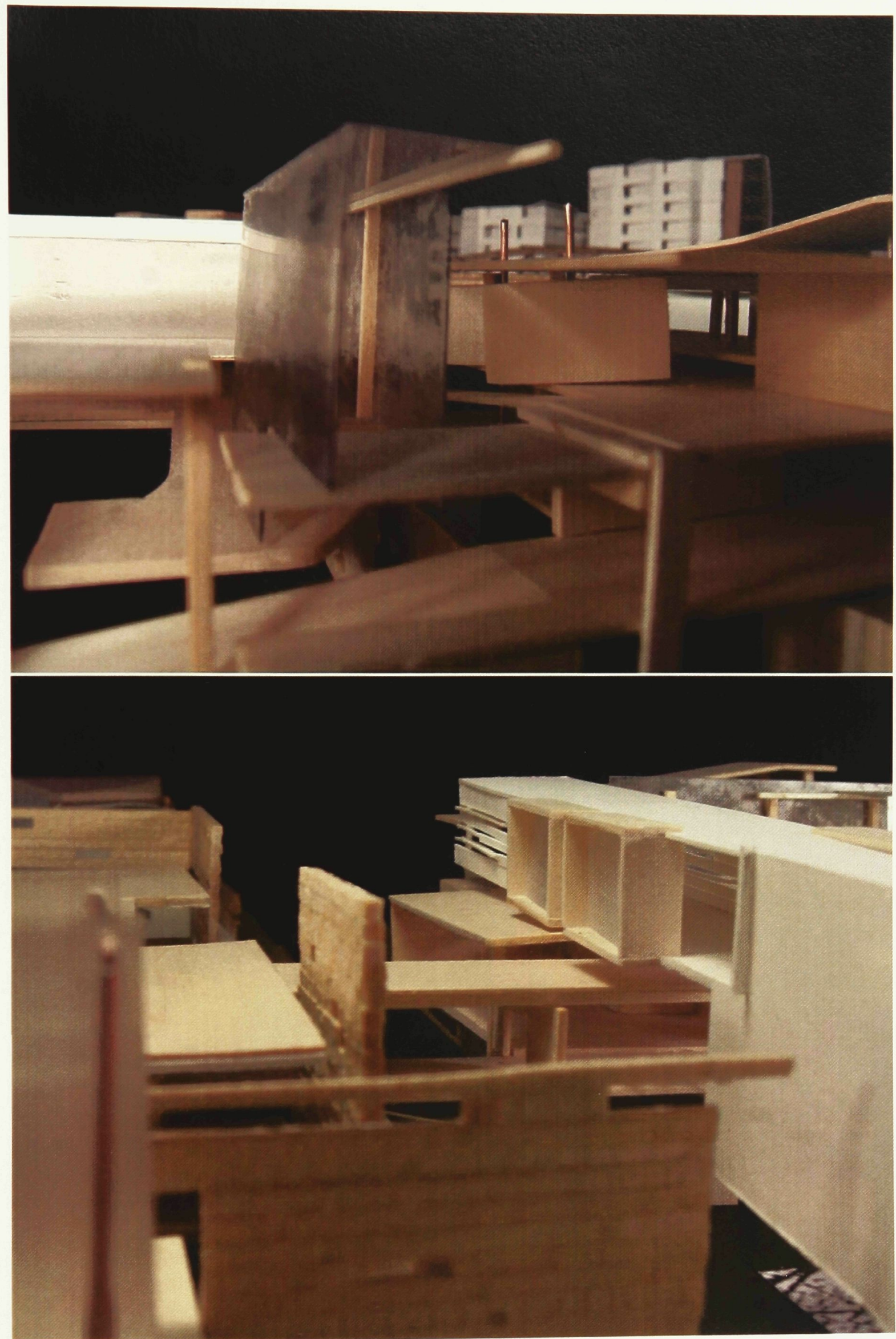

60: (top) showing stairwell and moving wall panels (bottom) office space overlooking residential and open space of mall. 


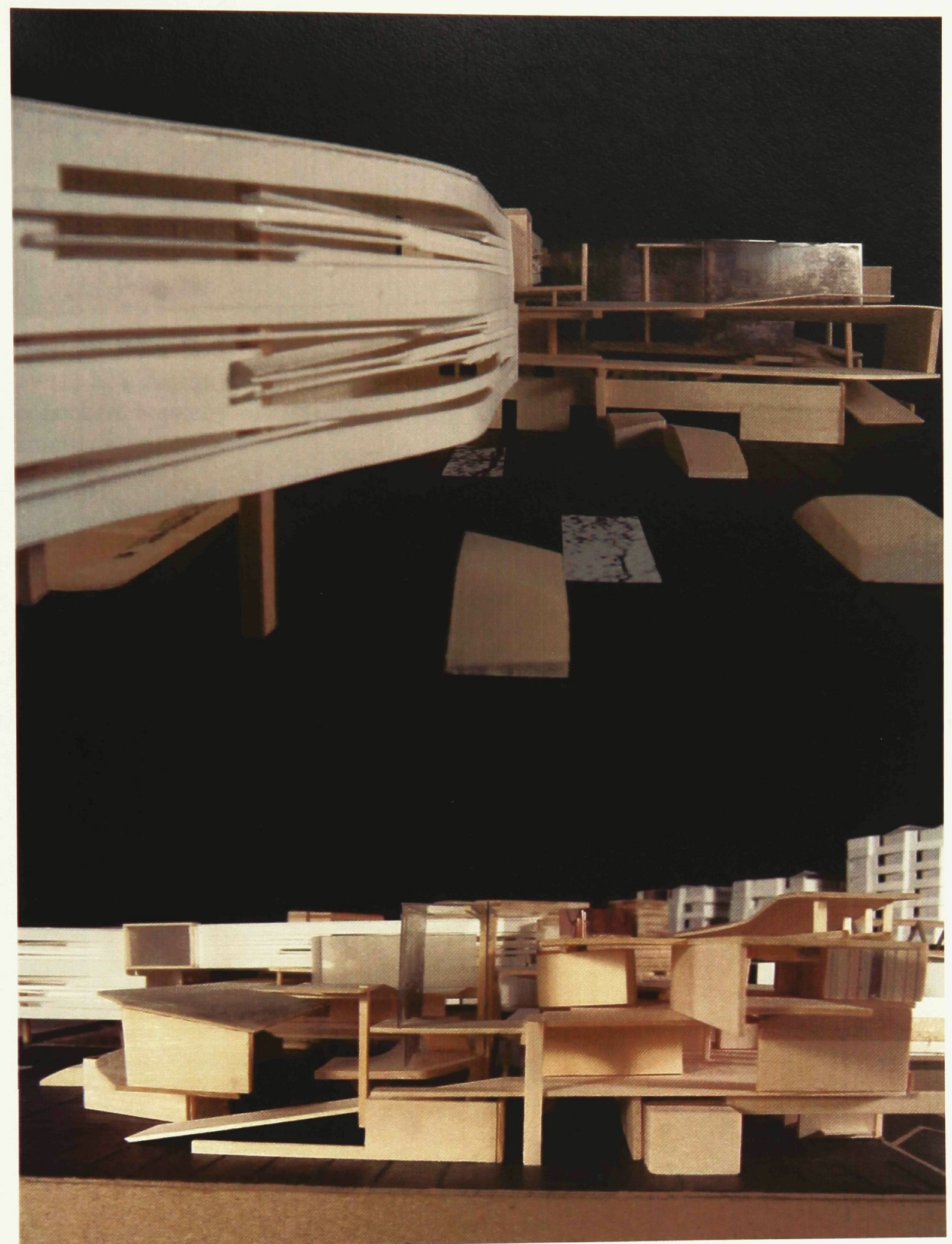

61: (top) office space and library entrance, (bottom) south facade of library. 


\section{Chapter 5 Notes}

${ }^{1}$ F.H. Armstrong and Daniel J. Brock. Reflections on London's Past. (London, Ontario: The Corporation of the City of London, 1975) 8.

${ }^{2}$ Ibid. 10.

${ }^{3}$ Peter G. Rowe, Making a Middle Landscape. (Cambridge: The MIT Press. 1991) 124. Attributed to Victor Gruen, the 'dumbbell' plan is defined by a pedestrian concourse between two large department stores, flanked on both sides by store fronts of smaller retail outlets.

${ }^{4}$ Statistics Canada 2001, "Westmount Planning District Summary" <www12.statcan.ca/english/census01/home/Index.cfm>

${ }^{5}$ See Appendix $A$ for further information.

${ }^{6}$ Buro Kiefer, "Play Parking Lot" <www.buero-kiefer.de>

${ }^{7}$ Curtis, William J.R. Modern Architecture: since 1900. (London: Phaidon Press Ltd., 2001) 34. 


\section{Conclusion}

This thesis examines the organizing structures of the suburban city as a means of developing a new typology of architecture that informs a Phantom Public Sphere by recognizing the transformations of the suburban territory and its consequent social, political and economic applications. As an initial investigation, 'interventions' have been explored as an exercise to examine the social constructs which unify the contradictions that occur in the public sphere of a mall. As critical actors in the context of the mall, the interventions constitute a proposal for a multi-functional building strategy. The addition of 'civic architecture' in the Westmount Shopping Center site is such an arrangement, corresponding with existing phenomena that are found on the site, such as pedestrian and vehicular circulation, distinct population groups, and seasonal and daytime uses.

The combination of layering, juxtaposition, and collage of urban and suburban typological symbols and ideations have assisted in the conception of a new suburban landscape. The removal of prohibitive public boundaries that exist on the site would produce alternatives to the authoritarian control the mall exerts over public activities and affiliations. Interwoven throughout the site, the public and private realms appear, meet and dissolve in a constant flux of events that are dependent on the relationships formed between the heterogeneous social groups at a particular juncture of space and time. Inhabiting the space in-between, the Phantom Public Sphere has the capability to remain dormant or unveil itself through new structures defined by experiential diversity and difference. The uncertainty of the Phantom Public Sphere allows the public realm to act as a multivalent outlet for a conflictual public realm to exist, while the proposed 
architecture spatially navigates between the realms that formalize public and private space. 


\begin{tabular}{|c|c|c|}
\hline 1 & $\begin{array}{l}\text { Do you shop as a social } \\
\text { activity? If so, do you prefer } \\
\text { to shop with family or } \\
\text { friends? }\end{array}$ & $\begin{array}{l}17 \text { yes }(13 \mathrm{~F} / 7 \mathrm{M}), 21 \text { no }(10 \mathrm{~F} / 8 \mathrm{M}) \\
2 \mathrm{w} / \text { family } \\
1 \mathrm{w} / \text { self } \\
14 \mathrm{w} / \text { friends }\end{array}$ \\
\hline 2 & $\begin{array}{l}\text { Would you shop more often } \\
\text { if there were other } \\
\text { recreational facilities in the } \\
\text { mall (ex. gym, library, etc.)? }\end{array}$ & 17 yes $(11 \mathrm{~F} / 6 \mathrm{M}), 21$ no $(12 \mathrm{~F} / 9 \mathrm{M})$ \\
\hline 3 & $\begin{array}{l}\text { What mode of transportation } \\
\text { do you take to the mall? }\end{array}$ & 19 bus $(13 \mathrm{~F} / 6 \mathrm{M}), 19$ car $(10 \mathrm{~F} / 9 \mathrm{M})$ \\
\hline 4 & $\begin{array}{l}\text { Do you think the mall } \\
\text { increases the aesthetic value } \\
\text { of the neighbourhood? }\end{array}$ & 23 yes $(12 \mathrm{~F} / 11 \mathrm{M}), 15$ no $(11 \mathrm{~F} / 4 \mathrm{M})$ \\
\hline 5 & $\begin{array}{l}\text { Do you think that the mall } \\
\text { gives identity to the } \\
\text { neighbourhood? }\end{array}$ & 22 yes $(20 \mathrm{~F} / 12 \mathrm{M}), 6$ no $(3 \mathrm{~F} / 3 \mathrm{M})$ \\
\hline 6 & $\begin{array}{l}\text { Do you believe that interior } \\
\text { and/or exterior public space } \\
\text { is necessary in the suburbs? }\end{array}$ & 26 yes $(12 \mathrm{~F} / 10 \mathrm{M}), 12$ no $(5 \mathrm{~F} / 7 \mathrm{M})$ \\
\hline 7 & $\begin{array}{l}\text { Do you consider the mall a } \\
\text { public space? }\end{array}$ & 34 yes $(20 \mathrm{~F} / 14 \mathrm{M}), 4$ no $(3 \mathrm{~F} / 1 \mathrm{M})$ \\
\hline
\end{tabular}

Q2. of the respondents that answered yes; the activities that they would like to see in the mall included, bar, "sit-sown" restaurant, gym, library, and strip bar.

Q6. of the respondents that answered yes to the importance of 'public' space; green space and seating or "rest" spots were mentioned.

Q. 7 One of the respondents stated that the public space of the mall was not the same as "[...] downtown space[...]".

\section{$\underline{\text { Conclusions }}$}

The survey suggests that the majority of people consider the mall a public space and at the same time believe that this particular space is necessary (question 6). The suggestions in question 6 regarding alternative outdoor green-space or an increased number of interior and exterior rest or bench areas would presume the lack of these facilities in the St. Laurent Shopping Centre. If the mall itself if a civic space and the 
need for more public space, as suggested by the respondents, would assume that the mall is not adequate in producing social space for the citizens of the suburbs. Also the integration of a comprehensive public transportation system would aid in the economic vitality of the mall. This would also suggest that additional population density in the territory of the mall, would help to support public transportation routes. 


\section{Bibliogrpahy: Primary}

Cha, Tae-Wook, Chuihua Judy Chung, Jutiki Gunter, et. Al. "Shopping”, Mutations: A Harvard Project on the City ed. Armelle Lavalou Barcelona: ACTAR, 2001

Chung, Chuihua Judy, Jeffrey Inaba, Rem Koolhaas, Sze Tsung Leong. Köln; The Harvard Design School Guide to Shopping, New York: Taschen ; Cambridge, Mass. : Harvard Design School, 2001.

Curtis, William J.R. Modern Architecture: since 1900. (London: Phaidon Press Ltd., 2001.

Deutsche, Rosalyn. "Agoraphobia". Evictions: Art and Spatial Politics. Cambridge: The MIT Press, 1996.

--- "Uneven Development: Public Art in New York City." Out of Site: A

Social Criticism of Architecture. Ed. Diane Ghirardo. Seattle: Bay Press, 1991.

Robert Fishman, Bourgeoisie Utopias (New York: Basic Books Inc. 1987)

---. Urban Utopias in the Twentieth Century: Ebenezer Howard, Frank

Lloyd Wright, and Le Corbusier. New York, New York: Basic Books, Inc. 1977.

Fraser, Nancy. "Rethinking the Public Sphere: A Contribution to the Critique of Actually Existing Democracy", Social Text vol. 25/26,1990. 56-80

Gruen, Victor and Larry Smith, Shopping Towns USA: The Planning of Shopping Centers New York: Reinhold, 1960. 11.

Goldring, Nancy "Highway Architecture." Ed. Womersley, Steve. SITE Identity and Density. Victoria: The Images Publishing Group Pty Ltd. 2005.

Hardwick, Jeffrey M. Mall Maker: Victor Gruen, Architect of an American Dream Philadelphia: University of Pennsylvania Press, 2004.

Koolhaas, Rem. "Generic City.” S,M,L,XL. Ed. Jennifer Sigler. New York: Monacelli Press, 1995. 1248-1994.

Kowinski, William Severnini. The Malling of America: An Inside Look a the Great Consumer Paradise. New York: William Morrow and Company, Inc. 1985.

Langman, Laura "Neon Cages: Shopping for Subjectivity". Lifestyle Shopping: The 
Subject of Consumption Ed. Rob Shields. Routledge: New York, 1992.

Lerup, Lars. After the City. Cambridge: The MIT Press, 2000.

Miles, Malcolm. Art Space and the City: public art and urban futures. New York: Routledge, 1997.

Miller, Daniel, Peter Jackson, Nigel Thrift, Beverley Holbrook and Michael Rowlands, Shopping, Place and Identity. New York: Routledge. 1998.

Mitchell, Don. The right to the City: Social Justice and the Fight for Public Space. New York: Guilford Press, 2003.

Phillips, Patricia, "Public Art: A Renewable Resource". Ed. Miles, Malcolm. Urban Avant

Gardes: Art, Architecture and Change, New York: Routledge, 2004, 122.

Rowe, Peter G. Making a Middle Landscape. Cambridge: The MIT Press. 1991.

Sola Morales, Ignasi de “Terrain Vague.” Anyplace. Cambridge: The MIT Press, 1995.

Wagner, George, "Shop Lift". Canadian Architect vol. 50.9 (2005)

Walls, Brian. Ed. If you Lived Here: The City in Art, Theory, and Social Activism. Seattle: Bay Press, 1991. 
Bibliography: Secondary

Allen, Stan. "Infrastructural Urbanism." Points + Lines: Diagrams and Projects for the City. New York: Princeton Architectural Press, 1999. 48-57

--- "Field Conditions." Points + Lines: Diagrams and Projects for the City. New York: Princeton Architectural Press, 1999. 92-135.

Armstrong, Fredrick H. and Daniel J. Brock. Reflections on London's Past. London: The Corporation of the City of London, 1975.

Auge Marc. "Non-places." Ed. Alan Read. Architecturally Speaking: Practices of Art, Architecture and the Everyday. New York: Routledge, 2000. 7-11.

Berman, Marshall. All That Is Solid Melts Into Air: The Experience of Modernity, New York: Simon and Schuster, 1982, $28-9$.

Carver, Humphrey, Cities in the Suburbs Toronto: University of Toronto Press. 1962.

Clammer, John. "Aesthetics of the Self: Shopping and Social being in contemporary Urban Japan”, Lifestyle Shopping: The Subject of Consumption Ed. Rob Shields. Routledge: New York, 1992.

De Certeau, Michel, The Practice of Everyday Life, trans. Steven F. Rendall Berkeley: University of California Press, 1984.

Dunham-Jones, Ellen. "Suburban Retrofits, Demographics, and Sustainability" Places vol.

17.2 (summer 2005)

Frumkin, Howard, Lawrence Frank, and Richard Jackson, Urban Sprawl and Public Health: Designing, Planning, and Building for Healthy Communities. Washington: Island Press. 2004.

Gandelsonas, Mario, X-urbanism: Architecture and the American City, New York: Princeton Architectural Press, 1999.

Gillham, Oliver, The Lmitless City: A Primer on the Urban Sprawl Debate Washington: Island Press, 2002.

Hardwick, M.Jeffrey. Mall Maker: Victor Gruen, Architect of an American Dream. Philadephia: University of Pennsylvania Press, 2004. 
Jacobs, Steven. "Shreds of Boring Postcards: Toward a Posturban Aesthetics of the Generic and the Everyday." Post Ex Sub Dis: Urban Fragmentations and Costructions. Eds. Ghen Urban Studiec Team (GUST). Rotterdam: 010 Publishers, 2002. 15-64. 121

Easterling, Keller. Organization Space: Landscapes, Highways, and Houses in America. Cambridge: The MIT Press, 1999.

Lippard, Lucy R. "Moving Targets/Moving Out." Art in the Public Interest. Ann Arbor: UMI Research Press, 1989. 209-228.

Payne, Andrew. "The Other Public." Ques, Rendezvous, Riots: Questioning the Public in Art and Architecture. Eds. George Baird and Mark Lewis. Banff: Walter Phillips Gallery, 1994. 57-72.

Peran, Marti. "Space Invaders(or Art between Dissolution and Distinction"., Space Invader: Artistic Interventions in Barcelona. Ed. 22a. Barcelona: Generalitat de Catalunya: Departament de Cultura, 2004.

Phillips, Patricia C. "Temporality and Public Art." Critical Issues in Public Art: Content, Context, and Controversy. Eds. Harriet F. Senie and Sally Webster. New York: HaperCollins Publishers, 1992. 295-304.

Robbins, Bruce, "Introduction: The Public as Phantom", The Phantom Public Sphere Minneapolis: University of Minnesota Press, 1993, xvii.

Shields, Rob. "The Individual, Consumption cultures and the fate of community", Lifestyle Shopping: The Subject of Consumption Ed. Rob Shields. Routledge: New York, 1992.

Simeoforidis, Yorgos, "The Challenge of the Critical Landscape", The critical Landscape.

Ed. Michael Speaks, Rotterdam: 010 Publishers, 1996

Soja, Edward. Postmodern Geographies: The Reassertion of Space in Critical Social Theory. London: Verso, 1989.

Venturi, Robert, Denise Scott Brown and Steven Izenour. Learning from Las Vegas: The Forgotten Symbolism of Architectural Form. Cambridge: The MIT Press, 1972.

Vidler, Anthony. The Architectural Uncanny. (Cambridge: MIT Press., 1992)

Wright, Frank Lloyd. "in the Cause of Architecture: the Logic of the Plan". Architectural Record, vol. 43, no.1 (Jan. 1928). 49. 


\section{$\underline{\text { Websites }}$}

Buro Kiefer, "Play Parking Lot" <www.buero-kiefer.de>

Statistics Canada 2001, "Westmount Planning District Summary" <www 12.statcan.ca/english/census01/home/Index.cfm>

Wikipedia, "6teen" <http://en.wikipedia.org/wiki/6teen> 